\title{
1. Statistical Methods for Social Scientists
}

By ERIC A. HANUSHEK and JOHN E. JACKSON

\section{A Volume in the QUANTITATIVE STUDIES IN SOCIAL RELATIONS Series}

Covering contemporary methods of quantitative analysis as used in sociology, economics, and political science, this text shows how to apply statistical methods in estimating and testing social science models. After an introduction to analytical modeling, the book develops simple regression methodsfor both single equation and multiequation models-and discusses their ap- plication and the complications that might arise. It features coverage of the increasingly important topics of qualitative dependent variables, errors of measurement, and unobserved variables. It also relates the techniques covered to more specialized areas such as path analysis and factor analysis. 1977, 372 pp., $\$ 19.00 / £ 13.50$ ISBN: $0-12-324350-5$

\section{Democracy in Deficit THE POLITICAL LEGACY OF LORD KEYNES} BY JAMES M. BUCHANAN and RICHARD E. WAGNER

This book examines the political economy of Keynesian economics. It treats the impact of economic ideas on political institutions and the effects of these derived institutional changes on economic policy decisions. It shows how Keynesian economics revised our fiscal constitution by revoking the constraint of a balanced budget, and-by a public choice analysis of Keynesian economics-shows why the actual his- tory of this theory's application fell far short of its glorious promises. It recommends a balanced budget constraint on the federal government as an institutional change to counteract those changes in institutions produced by Keynes' ideas and their application by politicians within our democratic framework.

1977, 202 pp. \$11.50/£8.15

ISBN: $0-12-138850-6$

\section{Mass Society}

By SALVADOR GINER

Dr. Giner traces the history of the concept of mass society from the early thinkers of Greece through Tocqueville, Marx, Nietzsche, Taine, Mannheim, Jaspers, Freud and Ortega to C. W. Mills, Marcuse, and other modern critics. He goes on to examine to what extent 'mass society' is a correct interpretation of the modern world and to what extent it is the brainchild of the fears and anxieties of disillusioned intellec- tuals and alarmed liberals. The several branches of the theory-the current doctrines about mass politics, mass culture, the levelling down of social structures-are critically assessed. In conclusion, practical proposals are made for useful social theorizing.

1976, 304 pp., $\$ 14.50$ ISBN: 0-12-284350-9

Academic Press Sales Territory: United States and Dependencies

\section{Send payment with order and save postage plus $50 \propto$ handling charge.} Prices are subject to change without notice.

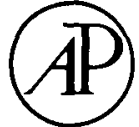

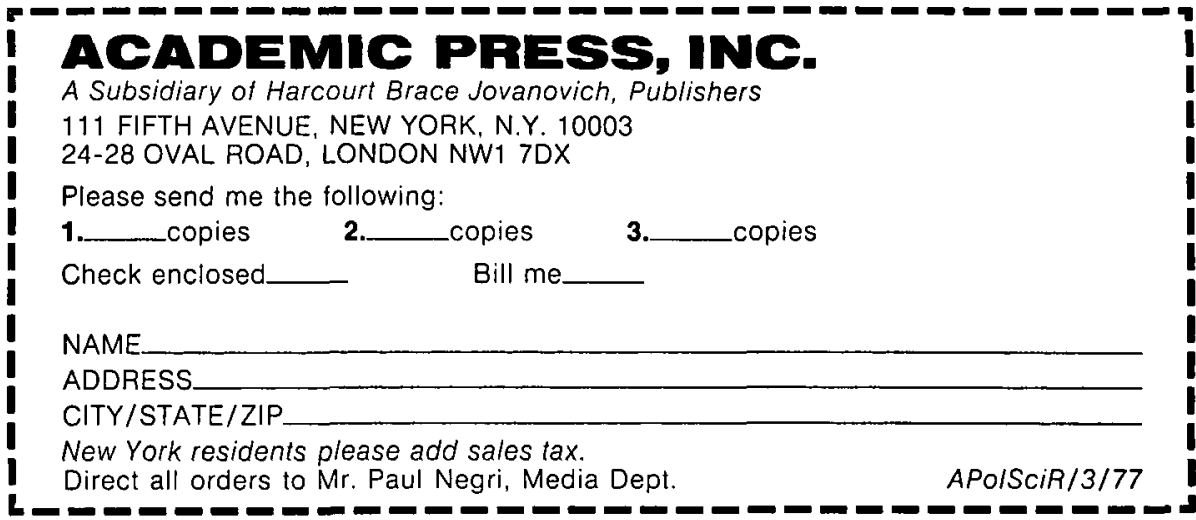




\section{Friends, Followers, and Factions}

\section{A Reader in Political Clientelism Edited by Steffen W. Schmidt, James C. Scott, Carl Landé, and Laura Guasti}

Of late attention to clientelist structures has increased. In political science the study of political middlemen or brokers, systems of patronage, and party factionalism has contributed to the study of clientelism. In assembling this reader, the editors have crossed disciplines and subject areas. Their selections move from anthropology, to sociology, to political science; from village to nation; from theory to case study; and from continent to continent. Despite constraints of length they have retained the scope and coverage that make the volume useful to a wide readership.

504 pages, $\$ 19.75$

\section{Regional Government and Political Integration}

Southwest China, 1949-1954

\section{Dorothy J. Solinger}

Solinger considers regionalism and political integration in southwest China during the years in which the country was divided into six Great Administrative Regions. She reviews the political, cultural, and economic separatism that was endemic in the Southwest during the Republican era and the administrative process by which the area was integrated into the Chinese nation. Earlier studies have focused more on cultural variations within nations than on administrative, political, and economic considerations. Hence, Solinger's particular contribution, in which both students of Chinese society and comparative analysts will find new insights and hypotheses.

300 pages, Maps, $\$ 17.00$

\section{Truth and Ideology}

\section{Hans Barth}

Translated by Frederic Lilge

Introduction by Reinhard Bendix

In this well-documented history of ideas, the late Swiss social philosopher Hans Barth traces the origin and historical transformation of the concept of ideology from Bacon through the eighteenth century down to Marx and Nietzsche. In a climate of wide-spread cynicism, Barth provides a cogent counter-argument and reaffirms the values indispensable to the continuance of a human community.

Hans Barth (1905-1965) was Professor of Political Science, Philosophy, and Ethics at the University of Zurich. 


\section{ELSEVIER}

Scholarly publishing since 1581

\section{Painters and Politics}

The European Avant-Garde and Society, 1900-1925

\section{Theda Shapiro, University of California-Riverside}

Based largely on unpublished materials, some unknown to art historians, PAINTERS AND POLITICS examines the political activities and social attitudes of a generation of avant-garde painters in Western Europe: the French Fauves and Cubists, the German Expressionists, and the Italian Futurists.

A landmark study for both art and social historians, this tastefully illustrated book will also fascinate anyone interested in avant-garde art and the European cultural scene.

1976361 pages $\$ 15.00$

\section{Revolutions and Revolutionaries}

\section{Four Theories}

\section{Barbara Salert, Washington University}

This study of revolution is a critical evaluation of four theories of revolution: rational choice theory, psychological theory, structural functionalism, and Marxism. These theories range from psychological explanations of motivations that induce people to join revolutionary movements to broad social explanations that focus on the socioeconomic and political conditions of societies that experience widespread violence.

1976192 pages $\$ 12.95$

\section{Power, Politics and Progress}

\section{Social Change in Rural Peru}

William Foote Whyte, Cornell University and Giorgio Alberti, University of Bologna

A description and analysis of peasant movements and the politics of community and regional change in a developing nation. Based on a 10-year research program, the story is told in simple, straightforward language. The field research is then examined in order to draw general conclusions on peasant movements and revolutionary theory; conflict, cooperation and power in peasant communities, and planned change and political processes. The authors also show how to examine developments at the community level in the context of major national changes in the distribution of power.

1976319 pages $\$ 15.00$

\section{Hitler Among the Germans}

\section{Rudolph Binion, Brandeis University}

HILTER AMONG THE GERMANS is a unique investigation of the psychodynamics of Adolf Hitler's rise and rule. The inner sources of Hitler's control over the German people are carefully uncovered as Binion traces the origins of Hitler's anti-Semitism and his extraordinary power to excite enthusiasm and disarm opposition. The wealth of new facts and insights presented in HITLER AMONG THE GERMANS makes it a landmark of historical scholarship.

"A remarkable book, notable in particular for its formidable scholarship and original research." - John Toland

1976224 pages $\$ 12.00$

\section{ELSEVIERNORTHHOLLAND ${ }^{\text {mc }}$}

52 VANDERBILT AVENUE NEW YORK, NEW YORK 10017 


\section{FULL AND FAST REFERENCE IN POLITICAL SCIENCE?}

\section{TRULY INTERNATIONAL COVERAGE?}

\section{IPSA TRIES HARD !}

Do you have easy access to the hundreds of journals which publish articles in political science, public administration and international relations all over the world? At a time when many libraries must take a close look at their budgets, can you and your students dispense with the ever fuller and faster services provided by INTERNATIONAL POLITICAL SCIENCE ABSTRACTS?

A non-commercial journal published by the International Political Science Association itself, the Abstracts provides summaries of articles in both specialized and non-specialized journals, including major yearbooks. Articles in English are abstracted in English; articles in other languages (approximately $30 \%$ ) are abstracted in French. From 1,450 abstracts in 1968 the progress has been to 5,039 abstracts in 1976. Each issue carries a detailed subject index and a list of the periodicals examined; the final issue of each annual volume contains a cumulative subject index and an author index. Back volumes are again available (trom vol. 1, 1951).

Your own Library should have a full set of the Abstracts. The institutional subscription for 1977 costs French Francs 350 (approximately $\$ 70$, £st. 39 ). Individuals may subscribe at a reduced rate of F.F. 100 (approximately $\$ 20$, £ st. 12).

INTERNATIONAL POLITICAL SCIENCE ABSTRACTS 27, RUE SAINT-GUILLAUME, 75007 PARIS, FRANCE 


\section{FACTIONAL AND COALITION POLITICS IN CHINA}

The Cultural Revolution and its Aftermath Y. C. CHANG

160 pp. Nou. 1976 LC 75-8404 ISBN 0-275-00920-3 $\$ 15.00$

\section{PERIODICALS ON THE SOCIALIST COUNTRIES AND ON MARXISM}

A New Annotated Index of English-Language Publications HARRY G. SHAFFER

154 pp. Dec. 1976 LC 75.36907 ISBN 0.275-24010.X \$16.50

\section{POLITICAL DEVELOPMENT IN EASTERN EUROPE}

Edited by JAN F. TRISKA and PAUL M. COCKS ca. 400 pp. March 1977 LC 76-19551 ISBN 0.275-23600-5 ca. \$25.00 PSS Student Edition: ISBN 0.275.89640.4 ca. \$6.95

\section{THE INTER-AMERICAN DEVELOPMENT BANK} AND POLITICAL INFLUENCE

With Special Reference to Costa Rica R. PETER DeWITT, JR.

ca. 200 pp. May 1977 ISBN 0.275.24460.1 ca. $\$ 16.50$

\section{THE NORDIC COUNCIL} AND SCANDINAVIAN INTEGRATION ERIK SOLEM

218 pp. Jan. 1977 LC 75.19824 ISBN 0.275.24100.9 \$18.50

\section{INDIVIDUAL RIGHTS AND THE STATE} IN FOREIGN AFFAIRS

Edited by ELIHU LAUTERPACHT and JOHN G. COLLIER ca. $800 \mathrm{pp}$. April 1977 ISBN 0.275.24350.8 ca. $\$ 45.00$

\section{POLITICS IN PUBLIC SERVICE ADVERTISING ON TELEVISION}

DAVID L. PALETZ, ROBERTA E. PEARSON, and DONALD L. WILLIS ca. 150 pp. Feb. 1977 LC 76.24363 ISBN 0.275.23880.6 ca. $\$ 15.00$

\section{PUBLIC LAW AND PUBLIC POLICY} Edited by JOHN A. GARDINER

266 pp. March 1977 LC 76-12851 ISBN 0-275-23320.0 ca. $\$ 20.00$ PSS Student Edition: ISBN 0.275.85750-6 ca. $\$ 5.95$

\section{EQUITY, INCOME, AND POLICY}

Comparative Studies in Three Worlds of Development Edited by IRVING LOUIS HOROWITZ ca. 350 pp. April 1977 LC 76-2904 ISBN 0.275.56570.X ca. $\$ 25.00$

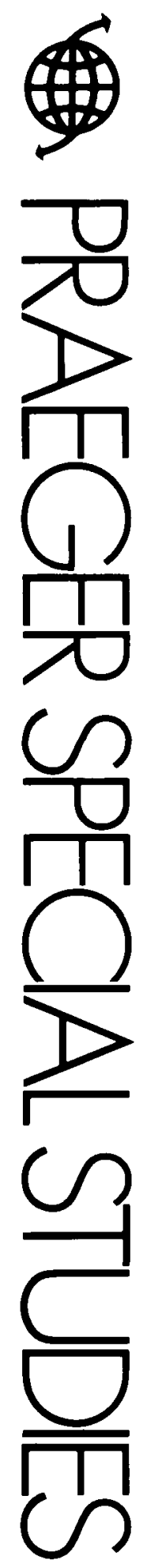



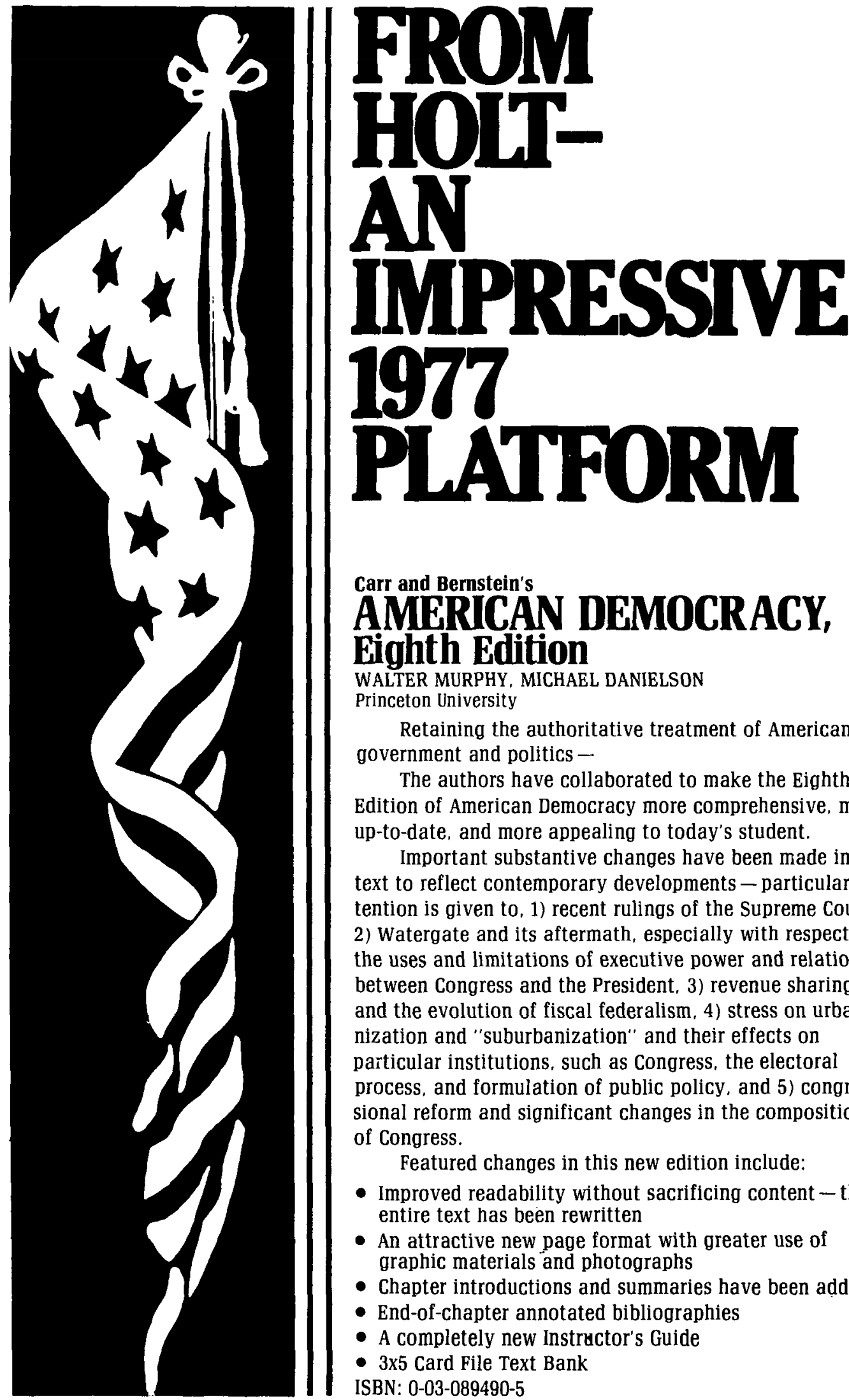

Carr and Bernstein's

AMERICAN DEMOCRACY, Eighth Edition

WALTER MURPHY, MICHAEL DANIELSON

Princeton University

Retaining the authoritative treatment of American government and politics -

The authors have collaborated to make the Eighth Edition of American Democracy more comprehensive. more up-to-date, and more appealing to today's student.

Important substantive changes have been made in the text to reflect contemporary developments - particular attention is given to, 1) recent rulings of the Supreme Court. 2) Watergate and its aftermath, especially with respect to the uses and limitations of executive power and relations between Congress and the President, 3 ) revenue sharing and the evolution of fiscal federalism, 4) stress on urbanization and "suburbanization" and their effects on particular institutions, such as congress, the electoral process, and formulation of public policy, and 5) congressional reform and significant changes in the composition of Congress.

Featured changes in this new edition include:

- Improved readability without sacrificing content - the entire text has been rewritten

- An attractive new page format with greater use of graphic materials and photographs

- Chapter introductions and summaries have been added

- End-of-chapter annotated bibliographies

- A completely new Instructor's Guide

- 3x5 Card File Text Bank

ISBN: 0-03-089490-5 
ESSENTIALS OF AMERICAN GOVERNMENT: Incomplete Conquest

THEODORE J. LOWI

Cornell University

A new. brief, paperback edition of the bestselling text, American Government: Incomplete Conquest. Using the thesis that government is best understood within the framework of conquest and control, this text provides a fascinating introduction to American institutions, politics and processes.

\section{Features:}

- Each chapter of the original text has been carefully reviewed, and all but two (Chapters $1 \& 14$ ) have been reduced in length

- Complete coverage through the 1976 Presidential Election

- A total instructional package is available, including: Instructor's Manual, Study Guide. Card File Test Bank. Filmstrip and a special taped interview with the author ISBN: 0-03-019886-0

\section{COMPARATIVE POLITICS, Second Edition}

PETER H. MERKL

University of California, Santa Barbara

Emphasizing political culture, socialization, parties and groups, and institutional structures - this introductory text covers all the major aspects of comparative politics without restricting itself to any one particular school of thought.

\section{Features include:}

- A unified, non-dogmatic approach - presenting views of the behaviorists, developmentatists, and institutionalists

- Flexibility - can be used as a core text with various other books on any country or topic

- Two chapters (5\& 6 ) on the institutional side of comparative politics

- A final chapter which sets the political system into the context of the institutional environment

- A selected bibliography of writings in all areas of comparative politics

ISBN: 0-03-088361-X

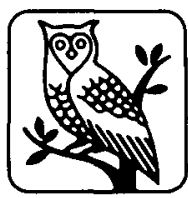

FOR FURTHER INFORMATION,

PLEASE CONTACT: JAMES T. RYDER

HOLT, RINEHART AND WINSTON

383 MADISON AVENUE

NEW YORK, N.Y. 10017

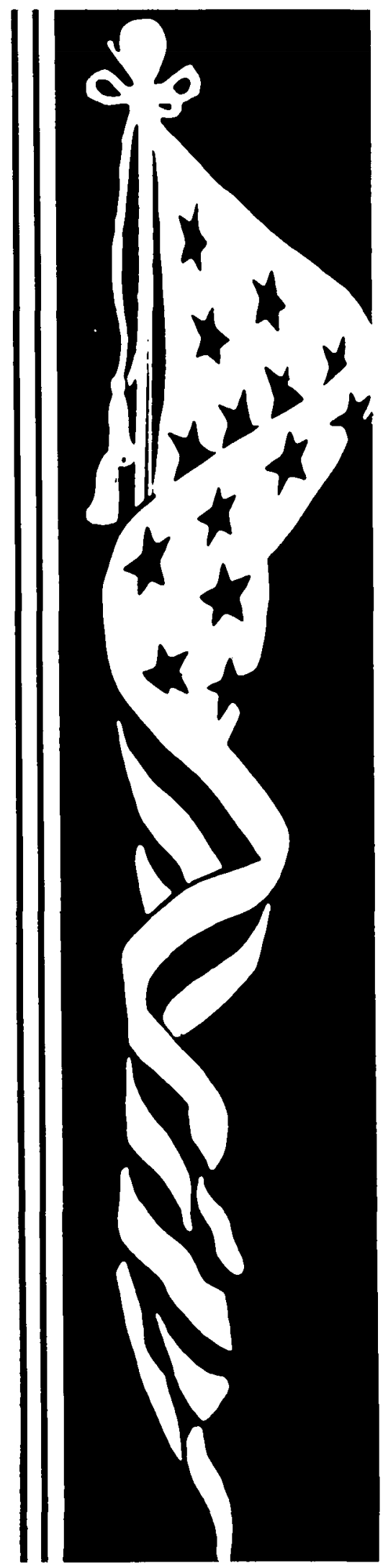




\section{CURRENT TOPICS IN POLITICAL SCIENCE FROM HALSTED PRESS, \\ A Division of \\ John Wiley \& Sons, Inc.}

\section{MODELS AND THE STUDY OF SOCIAL CHANGE}

By A.H. Galt and L.J. Smith, both of the University of Wisconsin-Green Bay.

ISBN 0-470-15156-0

$1976 \quad 180$ pp. Cloth $\$ 10.00$

ISBN 0-470-15163-3

$1976 \quad 180 \mathrm{pp}$. Paper $\$ 5.95$

(A Schenkman publication)

An interdisciplinary introduction to three basic models: the Ideal Type model, the Metaphorical model, and the analytical model. Important questions concerning the perspectives from which the social scientist proceeds in building theoretical statements are considered.

\section{EGYPT IN THE ARAB WORLD 1952-1970: The Elements of a Dynamic Foreign Policy}

By A.I. Dawisha, University of Lancaster. ISBN 0-470-19960-1

$1976 \quad 234$ pp. $\quad \$ 24.50$

A rigorous and systematic study of the structure and behavior of Egypt's foreign policy towards the Arab states. Emphasizes Egypt's regional activity under Nasser's charismatic leadership with a final chapter on Sadat's policies.

\section{WOMEN IN THE TWENTIETH CENTURY WORLD}

By Elise Boulding, University of Colorado ISBN 0-470-98947-5

$1976 \quad 256$ pp. $\quad \$ 15.95$

(A Sage Publications book)

Looks at the situation of women in global terms, as actors in various roles in national and transnational settings. The emphasis is on woman as problem-solver in the world community.

\section{HANDBOOK OF \\ INTERNATIONAL DATA \\ ON WOMEN}

By Elise Boulding, S.A. Nuss, D.L. Carson, and M.A. Greenstein.

ISBN 0-470-15183-8

$1976 \quad 468$ pp. $\$ 25.00$

(A Sage Publications book)

Now available in paperback....

\section{MARX AND MODERN \\ SOCIAL THEORY}

By A. Swingewood, London School of

Economics.

ISBN 0-470-98988-2

$1975 \quad 247$ pp. Paper $\$ 7.50$

POLITICAL TERRORISM

By Paul Wilkinson, University College,

Cardiff.

ISBN 0-470-98957-2

$1974 \quad 160$ pp. $\quad$ Paper $\$ 7.95$

Forthcoming....

\section{CONSTITUTIONAL} COUNTERREVOLUTION?

The Warren Court and the Burger

Court: Judicial Policy Making in

$$
\text { Modern America }
$$

By Richard Y. Funston, San Diego State

University.

ISBN 0-470-99022-8

$1977 \quad 387$ pp. Cloth $\$ 19.50$

ISBN 0-470-99023-6

$1977 \quad 387$ pp. $\quad$ Paper $\$ 8.95$

(A Schenkman publication)

Prices are subject to change without notice. For a 30-day examination copy of

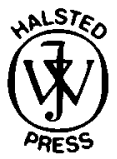
these books, write Dept. 52, Halsted Press, A Division of John Wiley \& Sons, Inc., 605 Third Avenue, New York, N.Y. 10016. 
PUBLIC ADMINISTRATION: Values, Policy and Change

Robert H. Simmons and

Eugene P. Dvorin,

both of California State University, Los Angeles

This introductory text, while providing a comprehensive historical, theoretical and practical account of the field, focuses on human values, social change and the role of the public administrator in society. Attention is given to state and local, as well as national, administrative systems. Through integration of orthodox and non-orthodox approaches and the use of a "macro" perspective, the reader is given a solid understanding of the is given a solid understionships of components of the
public administration process.

685 pages

$\$ 13.50 /$ hardcover

UNDERSTANDING POLITICAL SCIENCE: The Arena of Power

Ronald J. Stupak. The Federal

Executive Institute

Stuart C. Gilman,

University of Richmond

Craig E. Hartzer.

Miami University

This text surveys in crete language clear and con study in the main areas of pline. After political science discian introduction to the fielde, history and terminology of the field, each author focuses on his own area of specialization. These cover: political theory, methodology, inter national relations, comparative politics, and American politics.

325 pages
Michael J. Keller, Miami University Jeffrey P. Krans, Keuka College

Stephen H. Wainscott Clemson University

$\$ 6.95 /$ softcover

\section{OTHER ALFRED POLITICAL SCIENCE TITLES. .}

\section{POLITICS AND POWER IN AMERICAN GOVERNMENT:}

\section{An Introductory Text with Readings}

Sam C. Sarkesian and Krish Nanda, both of Loyola University of Chicago

This introductory text covers all basic areas and concepts of the American government system, while focusing on the manner in which political actors acquire, maintain and use influence for their own goals and for those associated with the system. Each chapter contains expository text, short reading selections on related issues, and questions for discussion.

555 pages

$\$ 9.95 /$ sof tcover

\section{THE ART OF POLITICS: Electoral Strategies and Campaign Management}

James Brown, Southern Methodist University

Philip M. Seib, Political Consultant

The format of this book is designed to provide the reader with a step-by-step guide to the practice of electoral politics.

250 pages

$\$ 5.95 /$ softcover

THE EUROPEAN COMMUNITY IN WORLD AFFAIRS: Political Influence and Economic Reality

Werner J. Feld, University of New Orleans

The main purpose of this text is to analyze the impact the European Community has had and is likely to have on economic and political relations in the world.

352 pages

$\$ 6.95 /$ softcover

\section{PUBLIC POLICY FOR THE BLACK COMMUNITY: Strategies and Perspectives}

Marguerite Ross Barnett, Howard University

James A. Hefner, Morehouse College

For the first time, a group of Black scholars examine a variety of public policy issues and the current position of Black Americans.

288 pages

$\$ 6.95 /$ softcover

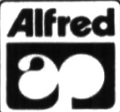

Alfred Publishing Co., Iric.

Dept. P.S.

75 Channel Drive

Port Washington, N.Y. 11050

To order an examination copy please indicate the course title, enrollment, and present texts used. 
The Brotherhood of Oil

Energy Policy and the Public Interest ROBERT ENGLER

Taking the 1973-74 energy scare as a case study, Engler traces the efforts of the merchants of oil to integrate all available energy resources into their empire. He then analyzes the political power that follows and shows that oil permeates every level of politics.

352 pages Cloth $\$ 12.50$

\section{Police: Streetcorner \\ Politicians}

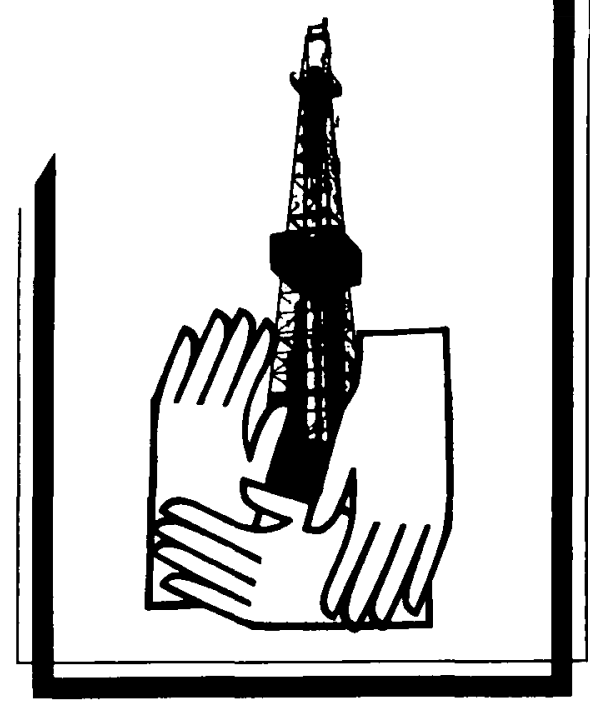

WILLIAM KER MUIR, JR.

Muir employs the results of a five-year case study of twenty-eight policemen to explore the difficulty of exercising coercive power.

320 pages Cloth $\$ 15.00$

\section{The Gray Lobby}

\section{HENRY J. PRATT}

This first full-length treatment of the development of federal policy toward the aged over the past two decades investigates the formulation of the agenda of public concerns.

$x, 250$ pages Cloth $\$ 15.00$

\section{Mass Society and the Extension of Welfare, 1960-1970 \\ KIRSTEN A. GR $\emptyset$ NBJERG}

Grønbjerg explores the pivotal role of changing concepts in citizenship in the welfare explosion.

256 pages Cloth $\$ 16.00$

The American Voter ANGUS CAMPBELL, PHILIP E. CONVERSE,

WARREN E. MILLER, AND

DONALD E. STOKES

576 pages Cloth $\$ 15.00$

\section{Tacitus in Renaissance} Political Thought KENNETH C. SCHELLHASE

"A mine of critical scholarship and an important contribution to European historiography." - Eric W. Cochrane, University of Chicago

288 pages Cloth $\$ 16.00$

\section{Black Men, White Cities}

Race, Politics, and Migration in the United States, 1900-30, and

Britain, 1948-68

IRA KATZNELSON

256 pages Paper $\$ 3.95$

\section{The University of Chicago Press}

Chicago 60637 


\section{Labor in American Politics \\ J. DAVID GREENSTONE}

With a new Introduction by the author

Creenstone argues for a new interpretation of organized labor's role in American national politics, maintaining that labor unions have committed themselves to broad policy objectives.

xxvi, 458 pages Paper TBA

The Limits of Liberty

Between Anarchy and Leviathan

IAMES M. BUCHANAN

"In this spirited defense of the idea of the social contract, Buchanan proposes a basically economic rationale for the organization of the state." - Virginia

Quarterly Review xi, 210 pages Paper $\$ 3.95$
Class, Citizenship, and Social Development ESSAYS BY T. H. MARSHALL

With an Introduction by Seymour Martin Lipset

"[This] collection of papers exhibits Marshall's remarkable capacity for linking up sociology of the past with sociology now evolving." - Robert K. Merton 394 pages Paper $\$ 7.50$

\section{Military Institutions and Coercion in the Developing Nations}

Expanded Edition of

The Military in the Political Development of New Nations

MORRIS JANOWITZ

A major new essay extends Janowitz's seminal work to the present.

Paper TBA

\section{Psychopathology and Politics HAROLD D. LASSWELL}

With a new Introduction by

Fred I. Greenstein

This important work features Lasswell's classic descriptions of such significant personality types as Political Man.

$$
\text { Paper TBA May }
$$

The Citizen and the State Essays on Regulation GEORGE J. STIGLER

"Stigler's theory is a challenging approach, pregnant with new interpretive approaches to twentieth-century history." - Reviews in American History 224 pages Paper $\$ 4.25$

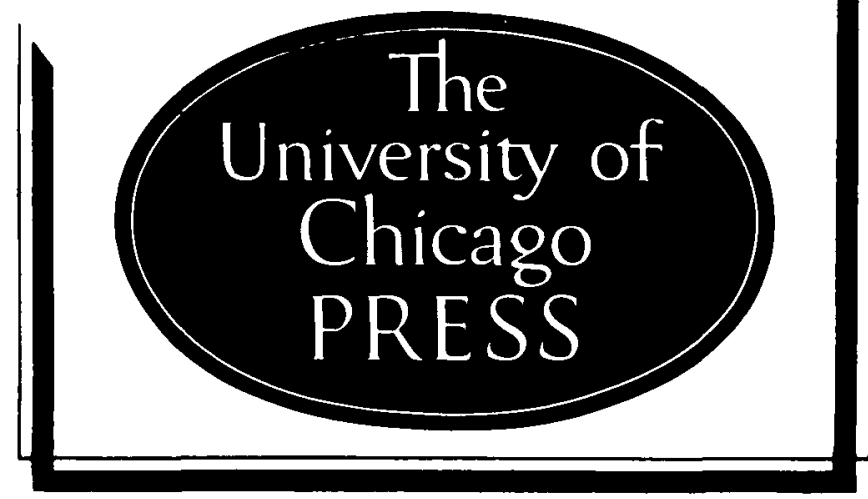




\section{$A$ New Annual Reference Publication}

\section{UNITED \\ STATES \\ POLITICAL SCIENCE DOCUMENTS}

Over the past ten years the political, social, and policy sciences have been inundated with an increasing flow of journal information. Not until now has a convenient sorting, filing, and evaluation process been developed to enable the academic community to keep up with the masses of information in a timely manner. This is why USPSD was created.
United States Political Science Documents (USPSD) is the published version of a computer-based file of political science information being developed continually by the University Center for International Studies, University of Pittsburgh, in conjunction with the American Political Science Association.

Volume I of USPSD will include between 2,000 and 2,500 documents published during 1975. The set will be available from UCIS Publications during the summer of 1976. For further information or to place your order, write to UCIS Publications at the address below.
USPSD will enable you conveniently to keep abreast of all the major journals in the field of political, social, and policy science, such as:

American Political Science Review

Comparative Political Studies

Comparative Politics

Economic Development and Cultural Change

Foreign Affairs

Foreign Policy

International and Intercultural

Communication Annual

International Development Review
International Education and Cultural Change

International Interaction

Intermational Organization

Intemational Relations

International Studies Quarterly

Journal of Conflict Resolution

Journal of Intermational Affairs

Policy Analysis

Policy Studies Journal

Studies in Comparative Communism

Studies in Comparative Intemational Development

World Affairs

World Politics 
USPSD will be an annual reference publication which examines and analyzes every article in over 120 major political, social and policy science journals.

Each entry in USPSD provides:

1. Author;

2. Title;

3. Journal Source and pagination;

4. An Abstract that describes the scope, purpose, methods employed, and results obtained in each article;

5. A listing of Special Features that include titles of all tables, graphs, figures, and maps used in each article;

6. A listing of Authors Cited in footnotes or references;

7. A listing of Key Subject Descriptors attributed to each article;

8. A listing of the major Geographic Areas referred to in each article;
9. A listing of Proper Names of organizations, political institutions, laws, etc. mentioned in each article.

USPSD will be published annually in TWO PARTS. The abstracts of the journal articles will comprise PART II and include those items listed above. PART I consists of five indexes to all the articles abstracted in Part II; they are divided according to:

1. Author(s) of each article;

2. Descriptor Subjects that are attributed to each article (The descriptions are taken from over 3,000 terms listed in the Political Science Thesaurus);

3. Geographic Areas referred to in each article;

4. Proper Names of organizations, political institutions, laws, etc. mentioned in each article;

5. Journal in which each article is published.

USPSD can be purchased as a two volume set-PARTS I \& II-or PART I, the indexes, can be purchased separately.

Prices for both are as follows:

\section{$\underline{\text { Regular price } \quad \text { APSA-member price }}$}

PARTS I \& II

(Index \& documents) $\quad \$ \$ 0.00$

$\$ 75.00$

PART I

(Index only)

$\$ 75.00$

$\$ 60.00$

University Center for International Studies

Publications Section

University of Pittsburgh

G-6 Mervis Hall

Pittsburgh, PA 15260

USA 


\section{From ब…}

texts designed to keep students on target

\section{BUREAUCRACY AND THE MODERN WORLD}

Victor A. Thompson (University of Florida)

This comprehensive text offers a moral or philosophical basis for organization without sacrificing the behavioral understanding gained in recent years. It sets forth the moral assumptions of modern institutions, especially those engaged in providing goods and services, both public and private.

1976150 pages paper, $\$ 5.95$

\section{CORRUPTION IN THE AMERICAN POLITICAL SYSTEM}

Larry L. Berg (University of Southern California), Harlan Hahn (University of Southern California), John R. Schmidhauser (University of Southern California)

The purpose of this book is to assist students and other citizens in a reappraisal of the sources of-and reasons for-the systemic corruption found in the very structure of American politics.

1976224 pages paper, $\$ 4.50$

\section{CONGRESSIONAL REFORM}

\section{IN THE SEVENTIES}

Leroy N. Rieselbach (Indiana University)

Indicating why Congress has not initiated public policy and suggesting that beneath this surface deference lies Congress' spirit of independence, this text discusses the first serious reform movement in the United States Congress in nearly three decades.

1977160 pages paper, $\$ 3.95$

For examination copies, write Director of Marketing
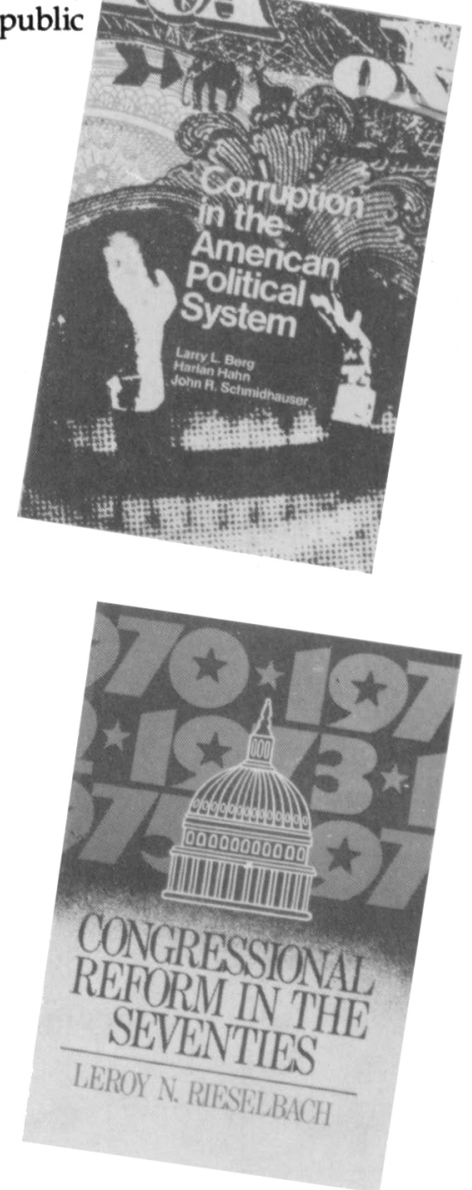

GP GENERAL LEARNING PRESS

Morristown, New Jersey 07960 Box APSR377

Available in Canada from GLC Publishers, Ltd., Agincourt, Ontario 


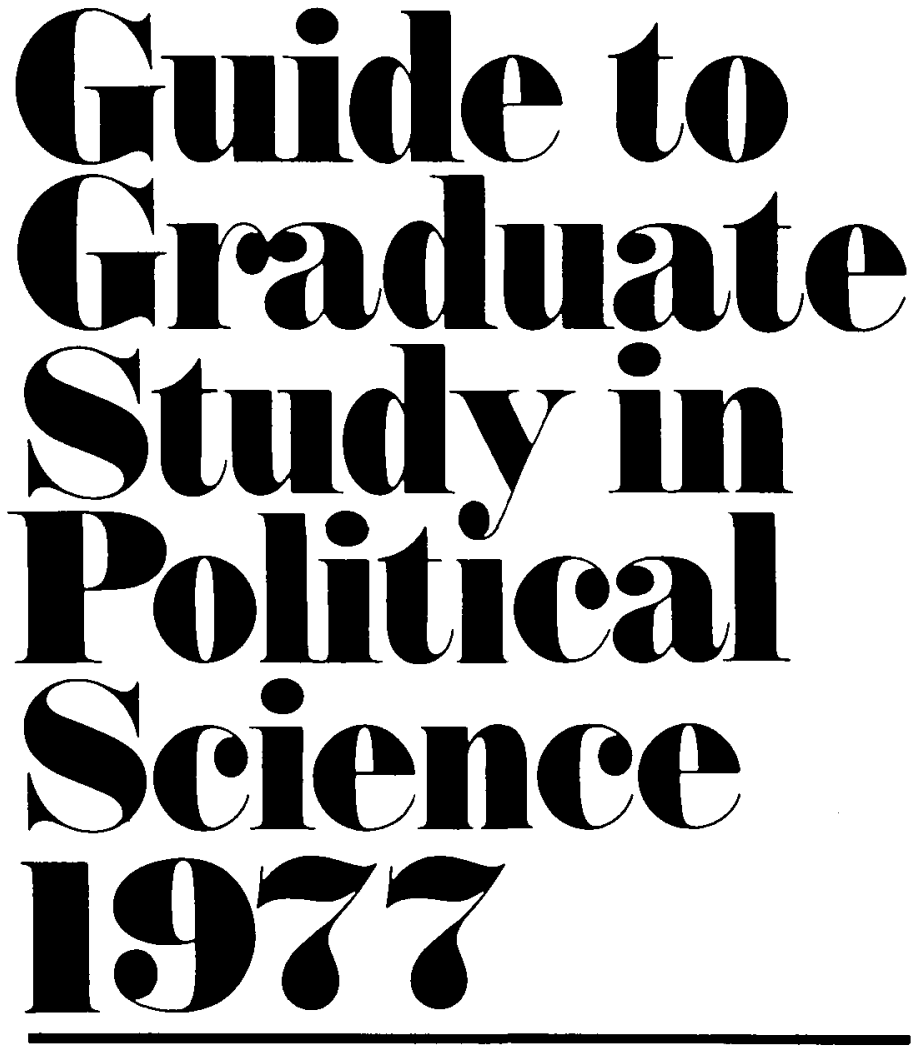

Revised Sixth Edition including names and fields of specialization of faculty

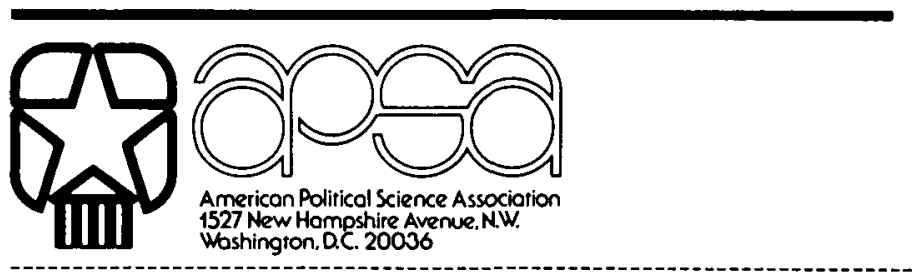

GUIDE TO GRADUATE STUDY IN POLITICAL SCIENCE - 1977

ORDER FORM

Ploase send me_copies of the 1977 GUIDE TO GRADUATE STUDY IN POLITICAL SCIENCE. Enclosed is my check for \$ cost at $\$ 4.00$ each.

\begin{tabular}{ll}
\hline NAME & \\
\hline ADDRESS & Return to: Amerlcan Political Sclence Assoctation \\
ALL ORDERS MUST BE & 1527 New Hampshire Avenue, N.W. \\
PREPAID & Washington, D.C. 20036
\end{tabular}




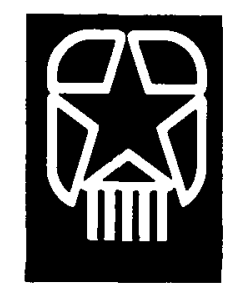

\section{Supplementary Empirical Teaching Units in Political Science:}

New computer related instructional materials whereby students learn important substantive topics in American politics as they learn methods of analysis.

\section{Seven SETUPS: American Politics \\ Are Available Now for Class Use}

1. Voting Behavior: The 1972 Election by Bruce D. Bowen, C. Anthony Broh, Charles L. Prysby.

2. Political Socialization Across the Generations by Paul Allen Beck, Jere W. Bruner, L. Douglas Dobson.

3. Political Participation by F. Christopher Arterton, Harlan Hahn.

4. The Supreme Court in American Politics: Policy Through Law by John Paul Ryan, C. Neal Tate.

5. U.S. Energy, Environment and Economic Problems: A Public Policy Simulation by Barry Hughes.

6. Representation in the United States Congress: 1973 by Ray A. Geigle and Peter J. Hartjens.

7. The Dynamics of Political Budgeting: A Public Policy Simulation by Marvin K. Hoffman. 


\section{Four SETUPS: Cross-National and World Politics Will Be Available for Class Use, Winter 1977}

1. Comparative Voting Behavior by Herbert B. Asher, Bradley Richardson.

2. The Budgetary Process in Cross-National Perspective by John Creighton Campbell, John M. Echols.

3. Conflict in the Middle East: A Public Policy Simulation by Karen Ann Feste.

4. Are Political Values Really Changing? by Charles Taylor.

Each SETUPS is a module that can be taught in one to two weeks. SETUPS were designed to supplement instruction in introductory courses. But SETUPS have been field tested successfully in upper division courses. SETUPS were developed by faculty in workshops supported by a grant from the National Science Foundation to the American Political Science Association and hosted by the Inter-University Consortium for Political and Social Research, summer, 1974 and summer 1975.

\section{Each SETUPS Module Includes a Monograph and a Data Set}

The monograph is a $5 \frac{1 / 2}{2}$ " $\times 1 \frac{1}{2}$ " paperback of approximately 100 pages with:

1. A substantive essay on the topic.

2. Analytical exercises.

3. Instructions about how to do the exercises.

4. Suggestions for further readings and exercises.

5. A code book for the data set.

The data sets are prepared and distributed by the Inter-University Consortium for Political and Social Research. SETUPS data can be ordered for use with SPSS, OSIRIS or as card image.

Each SETUPS will cost $\$ 3.50$. Lower prices are arranged for bulk orders. An order for 25 or more SETUPS will entitle you to the data sets for all the SETUPS at no extra charge.

\section{To Order SETUPS}

Order the SETUPS monographs from the American Political Science Association through your bookstore. Ask your bookstore to include your name when they place the SETUPS order with APSA. When we confirm the bookstore order, we shall send you a data-specification form if your school does not have the SETUPS data set already. 


\section{Listing and Order Form for Publications of the AMERICAN POLITICAL SCIENCE ASSOCIATION}

THE AMERICAN POLITICAL SCIENCE REVIEW. Quarterly journal of scholarly articles and book reviews in political science. Included in APSA membership. Back issues: $\$ 10.50$ per copy; $\$ 42.00$ per volume.

PS. Quarterly journal of Association news and articles of professional concern. Included in APSA membership. Back issues: $\$ 2.00$ per copy; $\$ 8.00$ per volume.

DEA NEWS FOR TEACHERS OF POLITICAL SCIENCE. Newspaper on education and the curriculum. Included in APSA membership.

ANNUAL MEETING PROGRAM. Final program for APSA Annual Meeting. Included in Annual Meeting Registration. Extra copies: $\$ .50$.

APSA ANNUAL MEETING PAPERS.** Hard copies, \$3.00 each.

APSA ANNUAL MEETING PROCEEDINGS.* * Microfilm reels of all papers, 1901-1912; 1956-present. \$22.00 per reel (approx. 7 reels per meeting).

CUMULATIVE INDEX TO THE AMERICAN POLITICAL SCIENCE REVIEW. * * 1906-1968, \$6.50.

Cumulative INDEX TO THE PROCEedings Of THE ANNUAL MEeTINGS.* Key word index to all papers included in proceedings of Annual Meetings for 1904-1912; 1956-1970; \$18.50.

WOMEN IN POLITICAL SCIENCE: STUDIES AND REPORTS, 1967-71 OF THE APSA COMMITTEE ON THE STATUS OF WOMEN IN THE PROFESSION. * * PB 486, $\$ 6.00$ microfilm; $\$ 16.50$ Xerographic reprint (U.S. prices).

POLITICAL SCIENCE THESAURUS. A major reference tool in political science; this volume represents the terminology control device for a computer-based information retrieval service. Individuals: Hardback, $\$ 20.00$; paper, \$15.00. Institutions: Hardback, \$30.00; paper, \$25.00.

APSA BIOGRAPHICAL DIRECTORY (Sixth Edition, 1973). Biographical information on over 7,000 Association members, plus names and addresses for approximately 12,500 members. Members: Hardback, \$7.50; paper, $\$ 5.00$. Non-Members: Hardback, $\$ 12.50$; paper, $\$ 10.00$.

APSA DIRECTORY OF MEMBERS: ANNUAL SUPPLEMENT TO THE APSA BIOGRAPHICAL DIRECTORY. Names and current addresses of all APSA members. $\$ 3.00$ each.

GUIDE TO PUBLICATION IN POLITICAL SCIENCE. Co-sponsored by the APSA Committee on the Status of Women and the Women's Caucus for Political Science. \$1.00.

ROSTER OF WOMEN IN POLITICAL SCIENCE (4th edition). Biographical information on women political scientists. $\$ 3.00$ each for members; $\$ 5.00$ for non-members.

ROSTER OF CHICANOS IN POLITICAL SCIENCE. Biographical information on Chicano political scientists. $\$ 3.00$ for members; $\$ 5.00$ for non-members.

ANNUAL APSA DIRECTORY OF DEPARTMENT CHAIRPERSONS. Names and addresses of Chairpersons of departments offering political science at four-year institutions. $\$ 20.00$ each.

PERSONNEL SERVICE GUIDELINES FOR EMPLOYERS AND APPLICANTS. Pamphlet containing information and guidelines for members of the APSA Personnel Service and for employers listing their vacancies in the Personnel Service Newsletter. No charge.

PERSONNEL SERVICE NEWSLETTER. Monthly listing of positions for political scientists. APSA Members: $\$ 8.00$ subscription.

CAREERS AND THE STUDY OF POLITICAL SCIENCE: A GUIDE FOR UNDERGRADUATES. A monograph discussing the relationship between political science knowledge and skills and careers in law, government, business, journalism, teaching, etc. $\$ .50$ each; bulk rates available.

\footnotetext{
* Order from: Customer Service Department

University Microfilms

300 North Zeeb Road

Ann Arbor, Michigan 48106
} 
CAREER ALTERNATIVES FOR POLITICAL SCIENTISTS: A GUIDE FOR FACULTY AND GRADUATE STUDENTS, by Thomas E. Mann. A monograph containing practical advice for obtaining nonacademic employment. \$1.00 each.

GUIDE TO GRADUATE STUDY IN POLITICAL SCIENCE. Compilation of Ph.D. and Masters programs in political science. The 1977 Guide is revised and expanded to include listings of faculty and fields of specialization. $\$ 4.00$ each.

SOURCES OF FINANCIAL SUPPORT FOR POLITICAL SCIENTISTS: RESEARCH EDUCATION, PROFESSIONAL DEVELOPMENT BULLETIN 1: SUPPORT FOR PROFESSIONAL DEVELOPMENT: FELLOW. SHIPS AND TRAINEESHIPS. Information on post-doctoral fellowships, internship programs, special training support and foreign travel grants available to faculty and advanced graduate students. $\$ 1.00$ each.

GLOBAL DIMENSIONS IN U.S. EDUCATION. A joint publication of the APSA Committee on Pre-Collegiate Education, the Education Commission of the International Studies Association, and the Center for War/Peace Studies of the N.Y. Friends Group, Inc. Four publications: The Elementary School, The Secondery School, The University, The Community. \$1.50 each, $\$ 5.00$ per set.

COMPARING POLITICAL EXPERIENCES. Complete description of an alternative course for high school government instruction. $\$ 2.75$ each.

SETUPS: AMERICAN POLITICS (Supplementary Empirical Teaching Units in Political Science). New computer related instructional materials whereby students learn important substantive topics in American politics as they learn methods of analysis. Voting Behavior: The 1972 Election by Bruce D. Bowen, C. Anthony Broh, Charles L. Prysby. Political Socialization Across the Generations by Paul Allen Beck, Jere W. Bruner, L. Douglas Dobson. Political Participation by F. Christopher Arterton, Harlan Hahn. Representation in the United States Congress: 1973 by Ray A. Geigle, Peter G. Hartjens. The Supreme Court in American Politics: Policy Through Law by John Paul Ryan, C. Neal Tate. U.S. Energy, Environment and Economic Problems: A Public Policy Simulation by Barry Hughes. The Dynamics of Political Budgeting: A Public Policy Simulation by Marvin K. Hoffman. For information and price list write: APSA Division of Educational Affairs. $\$ 3.50$ each; lower price on bulk orders.

INSTRUCTIONAL RESOURCE MONOGRAPHS. Guides on materiais and methods for teaching and learning in political science. A Guide to Library Sources in Political Science: American Government by Clement E. Vose, \$6.50 hardback, \$4.00 paperback. PSI and Political Science: Using the Personalized System of Instruction to Teach American Politics, edited by Ralph B. Earle, Jr., $\$ 3.50$ paperback. Simple Simulations, by Charles Walcott with Anne Walcott, $\$ 3.50$ paperback. Computer-Assisted Instruction in Political Science, edited by Jonathan Pool, $\$ 4.00$ paperback. U.S. Census Data for Political and Social Research: A Resource Guide, $\$ 4.00$, and U.S. Census Data for Political and Social Research: A Student Manual, \$2.50, both by Phyllis G. Carter. The Case of the Unreturned Cafeteria Trays by Lloyd S. Etheredge, $\$ 1.00$ each.

LEGISLATIVE SERVICE PROJECT MANUALS. Individuals manuals available for: Kansas, Kentucky, Montana, Ohio, Oregon, Rhode Island. $\$ 2.50$ each.

POLITICAL SCIENCE AND STATE AND LOCAL GOVERNMENT. A volume on the current and future state of research and educational programs in the field of state and local government. $\$ 3.75$ each.

APSA MEMBERSHIP MAILING LISTS AND LABELS. For information and price list, contact Membership Secretary, APSA.

APSA POLITICAL SCIENCE DEPARTMENT CHAIRPERSONS MAILING LABELS. For information and price list, contact APSA Departmental Services Program.

\section{Order Form}

I am enclosing a check for \$ for the following publications:

Name

Address

City State Zip

All orders must be prepaid.

Order from: American Political Science Association

1527 New Hampshire Avenue, N.W.

Washington, D.C. 20036 


\section{Five bright lights on the political scene.}

Morlan

\section{Capitol, Courthouse, and City Hall Readings in American State and Local Politics and Government, Fifth Edition}

Robert L. Morlan, University of Redlands About 336 pages, paper. Now available.

Retaining the excellent balance between state and local government and politics that made the previous editions so popular, the new Morlan treats contemporary issues such as the New York City financial crisis, the growing power of municipal employee unions, and no-growth or limited growth politics in land use control.

\section{Jones/Ericson/Brown/Trotter}

\section{Practicing Texas Politics, Third Edition}

Eugene W. Jones, Angelo State University

Joe E. Ericson, Stephen F. Austin State University

Lyle C. Brown, Baylor University

Robert S. Trotter, El Centro College

500 pages, paper, with Instructor's Manual.

Now available. Study Guide available April, 1977.

For the new Third Edition, Jones, Ericson, Brown, and Trotter retain the same effective balance of text and readings, but have updated the book throughout. They include new subjects such as the constitutional revision efforts of 1973-75, justice in Texas courts, money in Texas politics, and womanpower and Texas politics.

\section{Rouder}

\section{American Politics: Playing the Game}

Susan Rouder, City College of San Francisco

480 pages, paper, with Instructor's Manual. Now available.

Rouder's text is designed expressly to teach students how to get the system to budge at all levels of government. An excellent preparation for effective citizenship, American Politics introduces the American political process in a practical way. 


\section{Grieves}

\section{A World in Conflict: An Introduction to International Relations}

Forest L. Grieves, University of Montana

416 pages, with Instructor's Manual. Now available.

Grieves covers the basic concepts and background necessary for an understanding of modern international relations. Students get a chance to examine the kinds of issues that concern professional political scientists. These include the nature of the nation-state, prominent theories, and the historical context of modern world politics.

\section{Wesson}

\section{Foreign Policy for a New Age}

Robert G. Wesson, University of California, Santa Barbara 437 pages, with Instructor's Manual. Now available.

For upper-level courses in American foreign policy, Wesson's text provides a forward-looking study of the whole world of foreign policy and emphasizes various important factors ordinarily neglected, including economic aspects, psychological dimensions, relations with the Third World, and new kinds of problems in international affairs.

Turn the page for more on the political scene.

For adoption consideration, request examination copies from your regional sales office.

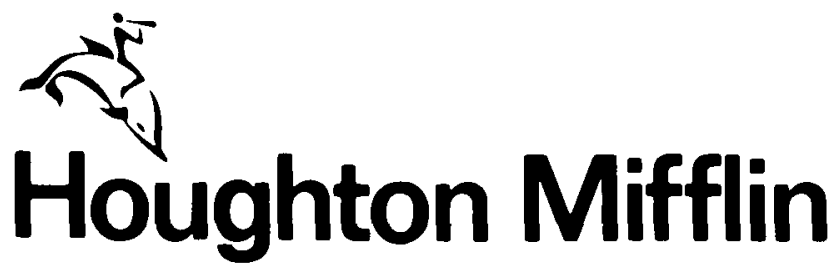

Atlanta, GA 30324 Dallas, TX 75235 Geneva, IL 60134

Hopewell, NJ 08525 Palo Alto, CA 94304 Boston, MA 02107 


\section{CAREER ALTERNATIVES FOR POLITICAL SCIENTISTS}

\section{A Guide for Faculty and Graduate Students}

\section{Thomas E. Mann}

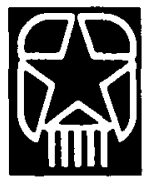

A Publication of the

Departmental Services Program

$\$ 1.00$ (prepaid)

20 pages

Available direct from:

The American Political Science Association

1527 New Hampshire Avenue, N.W.

Washington, D.C. 20036 


\section{IIOM APSA...}

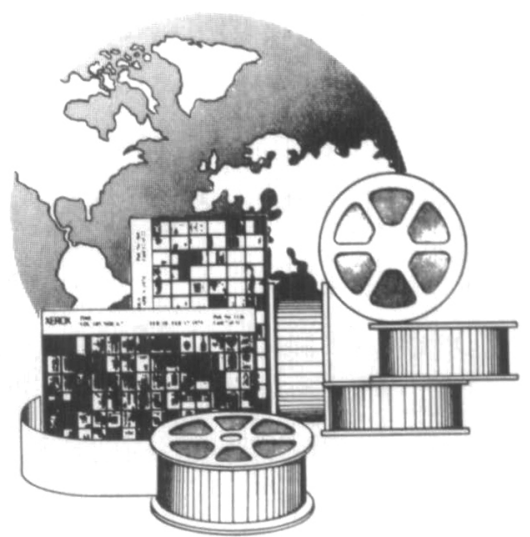

Cumulative Index to

Proceedings of the Annual Meetings

Key word index to all papers included in proceedings of Annual Meetings from $1904-12$ and $1956-70.887$ p. $\$ 18.95$ prepaid.

\section{APSA Annual Meeting Papers}

Hard copies, including 1976 Meeting Papers, $\$ 3.00$ each.

\section{APSA Annual Meeting Proceedings}

Microfilm reels of all papers, 1904-12 and 1956-76.

(Reels are \$27.00 apiece; each meeting in recent times runs from five to seven reels.)

\section{Cumulative Index to the American Political Science Review} 1906-1968, \$6.50 prepaid.

\section{American Political Science Review and PS}

Back issues in microform; prices available on request.

Available direct from:

University Microfilms Dept. F.A.

300 North Zeeb Road Ann Arbor, Michigan 48106
University Microfilms Dept. F.A

18 Bed ford Row London, WC1R 4EJ, England*

*When ordering from this address add $15 \%$ to the price of items. 


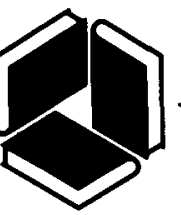

\title{
WAR, PEACE, AND INTERNATIONAL POLITICS
}

\author{
David W. Ziegler \\ Western Washington State College
}

Organized around the dramatic theme of war and its prevention, this new text provides an unusually coherent introduction to some of the basic concepts and propositions of international politics. The explicit intent of the author has not been to provide exhaustive coverage of the field, but rather to excite the interest of students. Ziegler takes a traditional, state-centered approach to his subject, providing a proper context for an understanding of the current "transnational" literature that reacts against this orientation. Wherever possible he provides concrete illustrations of abstract concepts. Material on some historical cases (Munich, Pearl Harbor, Korea) that bear on modern decision-making is included, along with maps that help students understand the significance of these incidents. An Instructor's Manual is available.

Paper approx. 464 pages March 1977 \$8.95 tent.

\section{POWER AND INTERDEPENDENCE World Politics in Transition \\ Robert O. Keohane \\ Stanford University \\ Joseph S. Nye \\ Harvard University}

Transnational politics - a contemporary theoretical approach to world politics, applied to four historically-extensive case studies. This text promises to be a path-breaking alternative to the traditional "statecentric" view of International Relations.

Paper approx. 300 pages January $1977 \$ 5.95$ tent.

\section{U.S. FOREIGN POLICY AND WORLD ORDER}

\section{James A. Nathan James K. Oliver \\ Both at the University of Delaware}

Successful new text that combines a comprehensive historical overview with an analysis of decision-making in U.S. foreign policy since World War II. Features a systematic, unifying theme: the evolution of military force and the threat of force as the primary instrumentality of American foreign policy.

Paper 608 pages $1976 \$ 10.95$

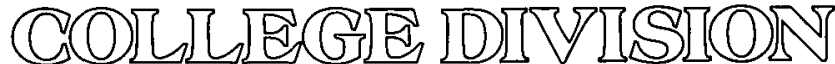




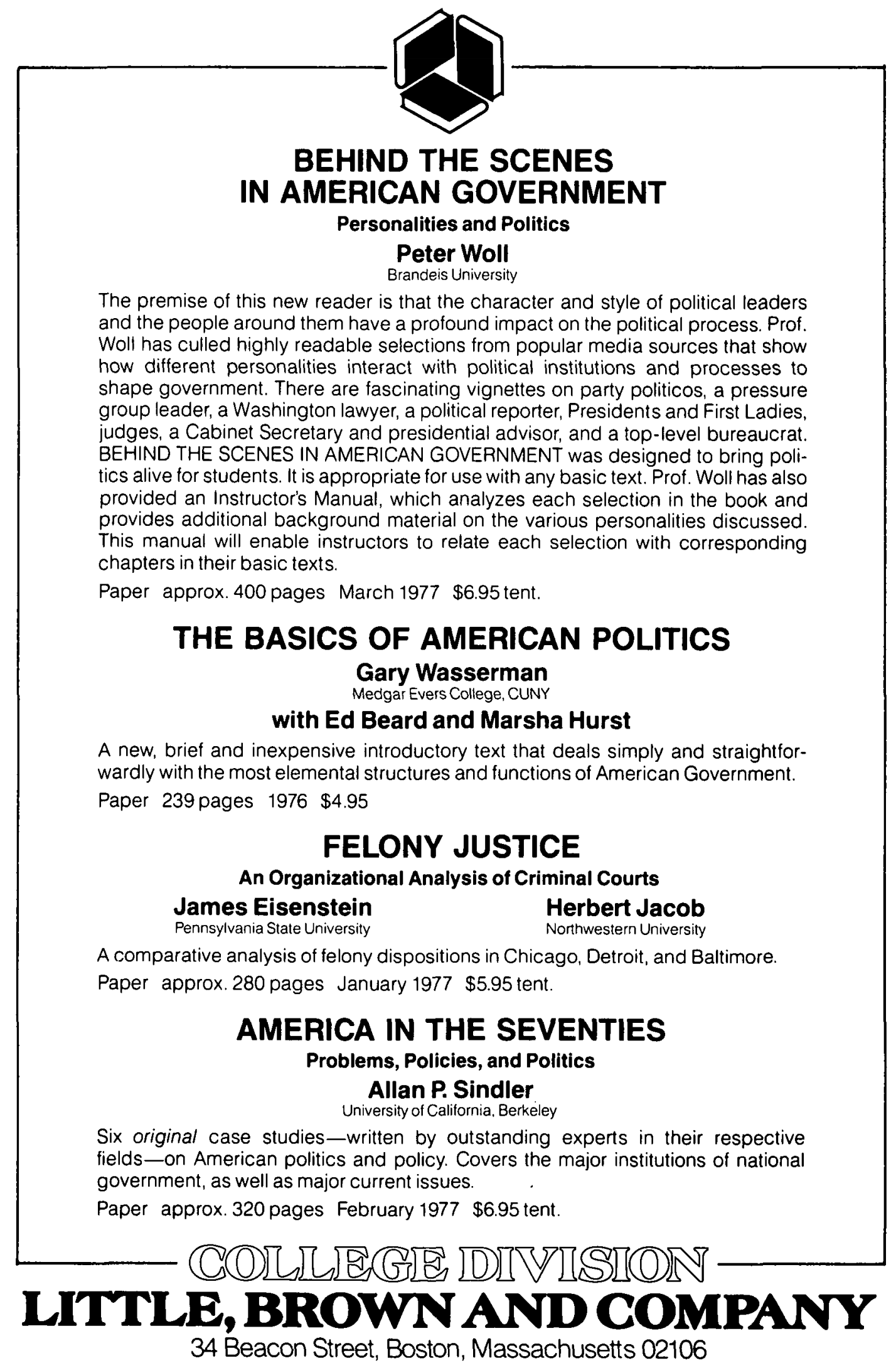

The American Political Science Review 


\section{Decisions from Princeton}

International Aid and National Decisions Development Programs in Malawi, Tanzania, and Zambia Leon Gordenker

In more than one hundred developing countries, international organizations continuously offer practical assistance for economic advancement and social change-assistance that in some cases forms a substantial part of national programs. This book examines international aid in three countries to ascertain how assisting organizations exert influence on member governments. "Highly recommended for its new perspective on the politics of foreign aid."-Library Journal Written under the auspices of the Center of International Studies, Princeton University $\$ 13.00$

\section{Perception and Misperception in International Politics \\ Robert Jervis}

"Prof. Jervis's new book will become a landmark in the study of psychological factors affecting foreign policy-making. It provides a major new critical synthesis of psychological theories and findings on perception and misperception, and indicates in a concrete, illuminating way their relevance for understanding how foreign policy-makers diagnose and deal with emergent situations in international politics."-Alexander L. George, Stanford University - Written under the auspices of the Center for International Affairs, Harvard University Cloth, \$22.50 Limited Paperback Edition, \$11.50

\section{Simulated Worlds \\ A Computer Model of \\ National Decision-Making \\ Stuart A. Bremer}

This book evaluates the Simulated International Processor (SIPER) model of the international political system, which was derived from the Inter-Nation Simulation model created at Northwestern University. Stuart Bremer makes a significant advance by programming all aspects of the basic theory so that it more completely and accurately reflects the complexity of international relations in the real world. $\$ 13.50$

\section{The Structure of Decision} The Cognitive Maps of Political Elites

\section{Edited by Robert Axelrod}

"This is the first book-length collection of articles employing an evolving, psychologistical approach that is likely to transform research in the decision making field. It is a very exciting empirical approach in that it subsumes causal modelling and rational choice theory as well as parts of cognitive psychology. Nothing else like it is now available."-Hayward R. Alker, Jr., M.I.T. - Written under the auspices of the Institute of International Studies, University of California and the Institute of Public Policy Studies, University of Michigan Cloth, $\$ 25.00$ Limited Paperback Edition, $\$ 9.95$

\section{Now in Paperback}

THE CYBERNETIC THEORY OF DECISION

New Dimensions of Political Analysis • JOHN D. STEINBRUNER

"A stimulating and challenging work.... Steinbruner's important and creative study successfully adds a new dimension to our understanding of decision-making."-Foreign Affairs $\$ 4.95 \bullet$ (Cloth, \$14.50)

PRINCETON UNIVERSITY PRESS

Princeton, New Jersey 08540 


\section{Congress-Keystone of the Washington Establishment}

Morris P. Fiorina

This concise and highly readable book makes a strong case that a Washington Establishment does indeed exist. Fiorina argues that, contrary to what is popularly believed, the bureaucrats are not the basic problem-Congressmen are. His description of the self-serving interconnections that have developed between Congressmen, bureaucrats, and citizens with special interests leads to provocative and disturbing conclusions about the way our political system works.

Cloth $\$ 8.50$ Paper $\$ 2.95$

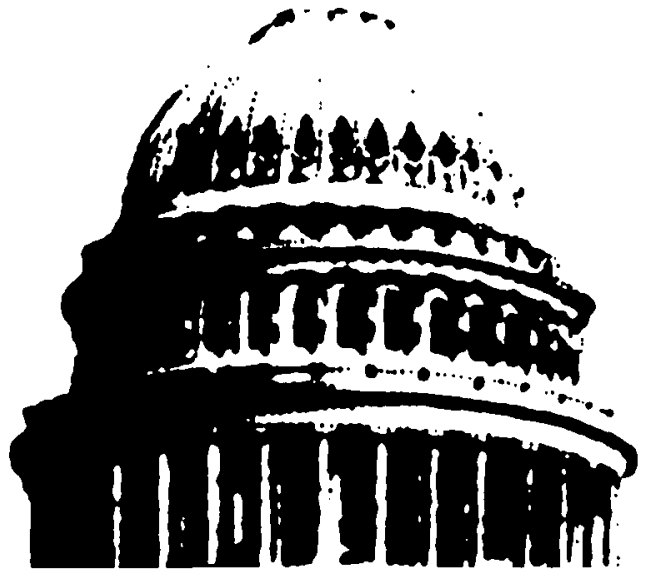

\section{The Ages of American Law}

Grant Gilmore

Gilmore's reflections on the American approach to law since the eighteenth century suggest lessons to be learned from the experience of the past two hundred years while demonstrating that law never has been, and never will be, the salvation of any society. $\$ 10.00$

\section{To Be A Politician}

Revised edition

Stimson Bullitt

Foreword by David Riesman

In this fascinating book, a lawyer who once ran for Congress reflects on what it is like to be a politician in our society. Bullitt describes the limits and opportunities of the politician's life and relates this broadly to the human condition and the problems of society with which politicians must deal. \$15.00

\section{The Collapse of Liberal Impire}

Science and Revolution in the Twentieth Century

Paul N. Goldstene

Goldstene probes the question of what liberals are really all about, as opposed to what they think they are about, while pursuing the reasons for the present crisis of the American order. $\mathrm{He}$ emphasizes the impact of a postindustrial political economy on liberal power relationships, stressing the power realities of a system increasingly dominated by a corporate presence.

"This is an incredibly provocative and thoughtful argument that conceivably could become the center of much concern."-Isaac Kramnick $\$ 10.00$

\section{Private Property and the Constitution}

Bruce A. Ackerman

A study of the uncertain constitutional foundations of private property in American law and a discussion of two vastly different methods by which courts may resolve the confusion. \$ 2.95

Now available in paper

\section{The Morality of Consent}

Alexander M. Bickel

"An illuminating, often a moving book, with all of Professor Bickel's rare ability to bring law to life in vivid words."--Anthony Lewis

Cloth $\$ 10.00$ Paper $\$ 2.95$

\section{Yale University Press}

\section{The Tides of Power}

Conversations on the A merican Constitution

Bob Eckhardt, Member of Congress from Texas, and Charles L. Black, Jr., Sterling Professor of Law, Yale University

"Absorbing as well as enlightening. Congressman Eckhardt, a Texas liberal, illuminates the day-today practical side of Congressional functions, while Professor Black presents the historical and theoretical perspectives."-Publishers Weekly Cloth \$10.95 Paper \$2.95 

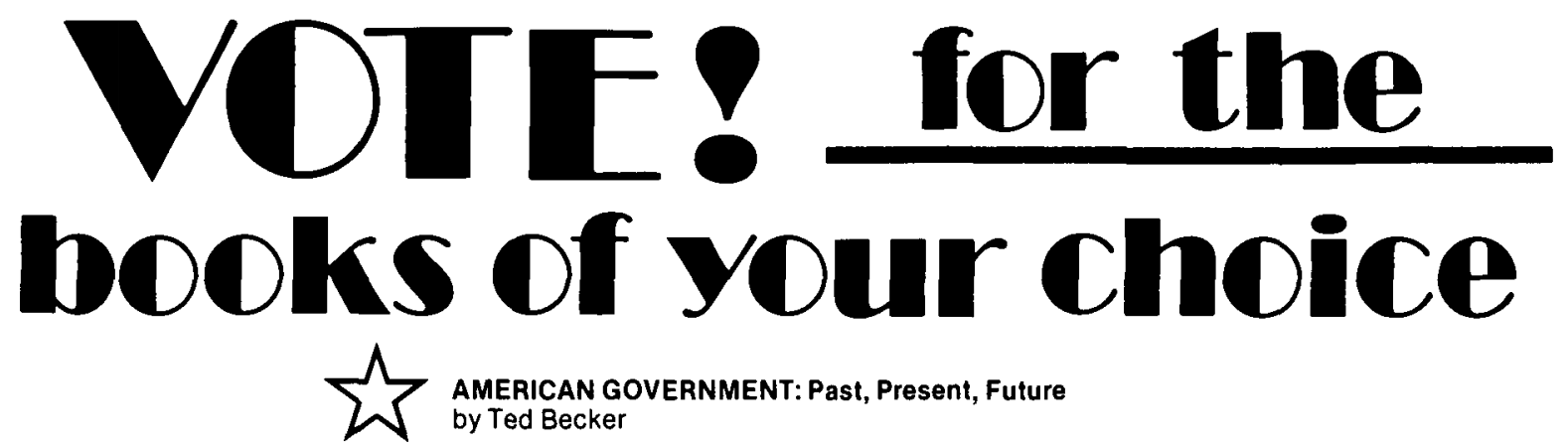

Approaching American politics as a novel blend of political ideology, governmental structure, and constitutional law, this text guides the beginning student through the origins of constitutional ideology, the decline of the original and traditional political ideologies, official lawlessness and political corruption plus suggestions for re-evolution. The text responds to student apathy and cynicism by directing students to the problems of involvement in the system - agreeing that the system is out of whack, but asserting that it is not doomed. It analyzes the nuts and bolts, telling not only what the system allows but how it gets away with it. 1976, 6-13/16 x 9-1/4, Paperbound, $544 \mathrm{pp}$.

"An intriguing textbook... Sound presentation of political science perspective and data, and the proposed changes of the system are very stimulating." J. Nichols, California State University at Hayward

\section{¿ THE DEVELOPING NATIONS: A Comparative Perspective \\ by Robert E. Gamer}

Requiring no prerequisites, this text thoroughly explores the politics of developing nations in Asia, Africa, and Latin America with unusual simplicity, clarity, and insight. The book compares the developing nations of Africa, Asia, and Latin America with one another. It compares these with the developed nations, the past with the present, theory with practice, conflicting points of view about development, forms of government, various policy initiatives, and past performance with future prospects. 1976, 6 × 9, Paperbound, $393 \mathrm{pp}$.

\section{is POLITICAL ANALYSIS: An Introduction, Second Edition \\ by M. Margaret Conway and Frank B. Feigert}

Rewritten with the undergraduate in mind, the second edition focuses on the development of explanatory theory in modern political science. An extensive and selected review of political science literature is presented dealing with research in American and comparative politics, international relations, public administration, and the growth of macro and micro theories. New to this edition is a chapter on research methods, a glossary, an expanded chapter on decision making and study questions at the end of each chapter.

1976, 6 × 9-1/4, Paperbound, $369 \mathrm{pp}$. is THE JUDICIARY: The Supreme Court in the Govern mental Process, Fourth Edition by Henry J. Abraham

Totally updated - through the 1975-76 term of the Supreme Court and the latest developments in Constitutional law - the new fourth edition continues to be an explanatory and analytical treatment of the nature of the Supreme Court and it s work. Succinct yet thorough, this edition covers the changes from the Warren Court to the Burger Court. The political nuances of the Court's decisions are discussed, and the important chapters on civil rights and liberties have been rewritten to reflect the manifold changes that have taken place since the previous edition. Jan. 1977, 5-1/2 × 8-1/2, Paperbound, est. 240 pp. 


\title{
NEW POLITICAL SCIENCE TEXTS AVAILABLE NOW!
}

\author{
$\sum$ \\ UNVOTE FOR A NEW AMERICA \\ by Ted Becker, Paul Szep and Dwight Ritter \\ UNVOTE FOR A NEW AMERICA takes off at the point where other Amer. \\ ican Government texts conclude - the apathetic electorate. It presents a \\ dynamic approach to American politics which is positive, practical, and \\ very American. It proposes such novel institutions as UNVOTING - \\ today's active program for continuing the constitutional revolution that \\ originated in America 200 years ago with Thomas Jefferson, and the \\ UNVOTER, not a passive nonvoter, but rather a sound middle-class citizen \\ who refuses to participate in a deteriorating system. Serious, without \\ taking themselves seriously, the authors, political scientist and lawyer Ted \\ Becker, Pulitzer-prize winning cartoonist Paul Szep, and educator Dwight \\ Ritter give your students insight for meaningful class discussions of the \\ American political system. \\ $1976,7 \cdot 1 / 8 \times 9-1 / 8$, Paperbound, $195 \mathrm{pp}$.
}

\begin{abstract}
"Szep is a Daumier of the 20th Century. Becker's prose reflects a creative, refreshing approach to governmental reform which is long overdue. The combination of the two yields a portrait of the foibles of the American political scene which is witty, easily comprehended, and true - a rarity in both literature and politics."

The Honorable Michael J. Harrington, U.S. House of Representatives
\end{abstract}

\section{is PARTIES AND POLITICS IN AMERICA} by Frank B. Feigert and M. Margaret Conway

Intended for courses in American Government, political parties and electoral behavior, this text examines the origins and functions of U.S. political parties and contrasts them with other political entities. Party elements and their interrelationships are presented. The environmental factors which shape the nature of American political parties and their operating characteristics are also discussed. Thorough presentations are included of the different theories of voting behavior, political participation patterns of both blacks and women as well as cur. rent research findings.

$1975,6-1 / 8 \times 9-1 / 4,432 \mathrm{pp}$.

\section{is THE CRAFT OF PUBLIC ADMINISTRATION by George E. Berkley}

Intended for any public administration course, this readable introductory text discusses the anatomy and physiology of organization; personnel practices and problems; leadership; communication; budgeting including PPBS and productivity measures; centralization; planning and other techniques for change; administrative flow and control; and mobilization of support from clients. Without neg. lecting theoretical issues, the book focuses on the kinds of problems public administrators face and how to solve them.

$1975,6 \cdot 3 / 16 \times 9-1 / 4,504 \mathrm{pp}$.

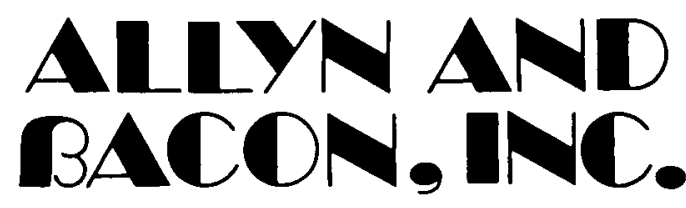

College Division, Dept. 893 - 470 Atlantic Ave., Boston, MA. 02210 


\begin{tabular}{|c|}
\hline 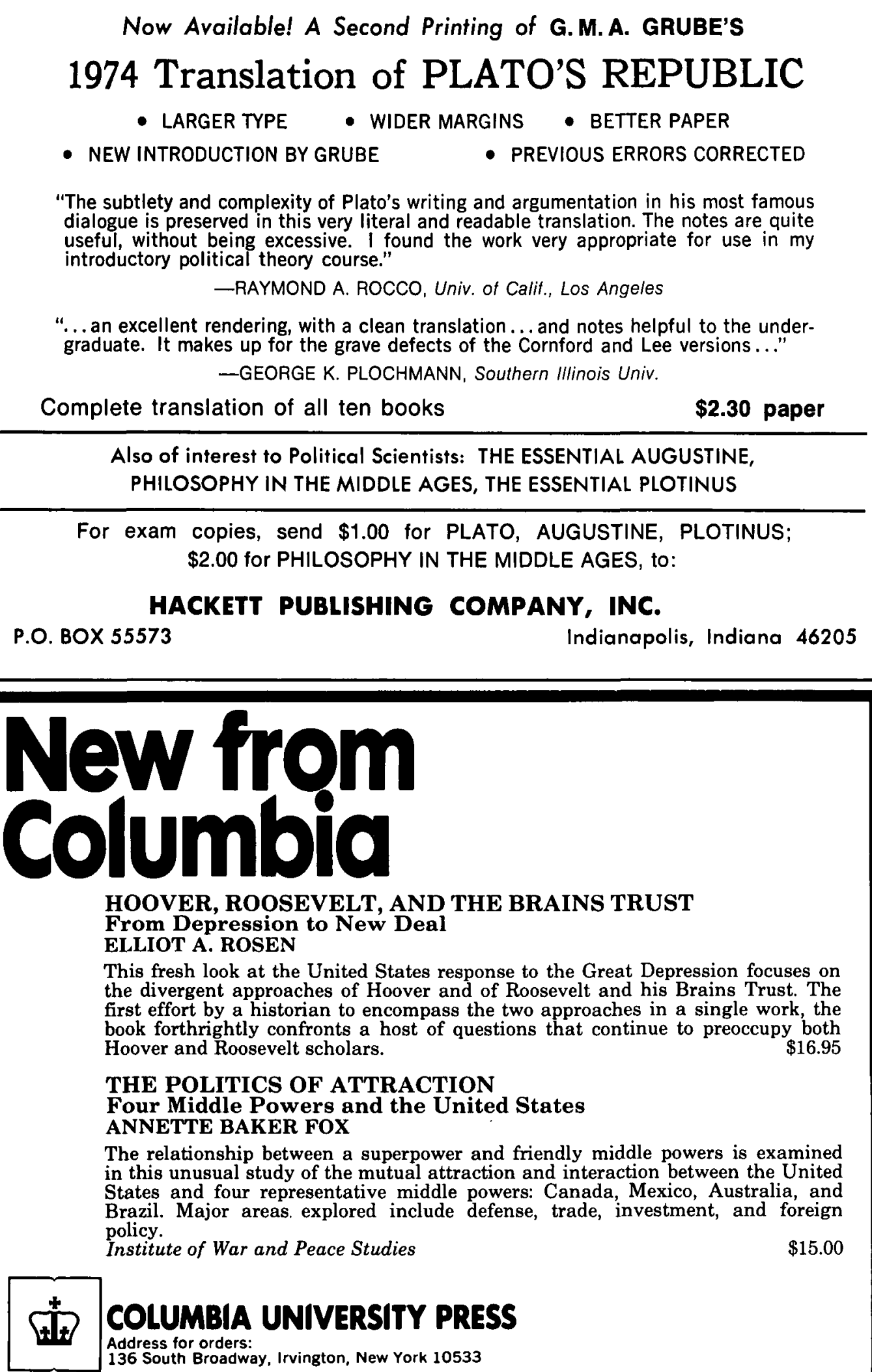 \\
\hline
\end{tabular}




\section{Announcing}

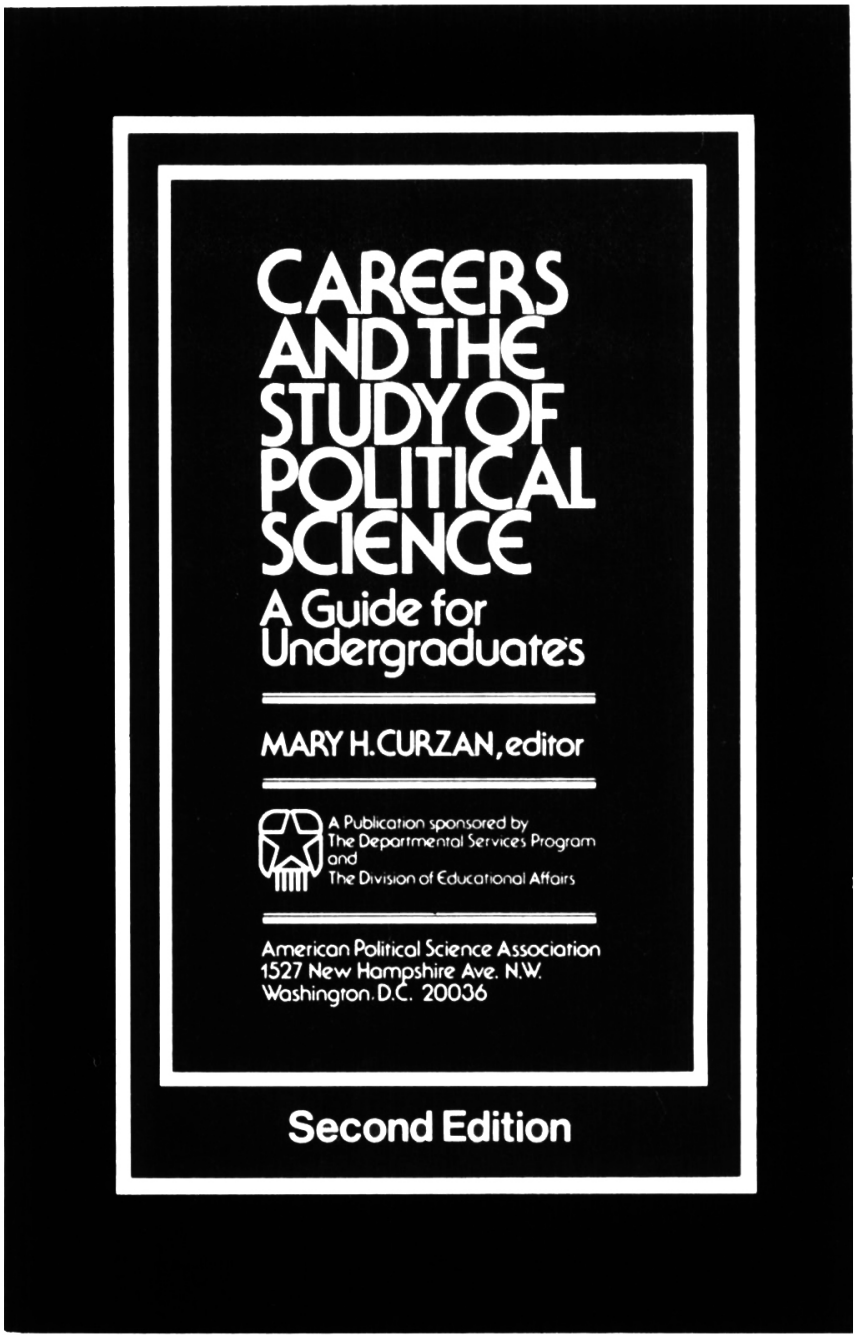

\section{ORDER FORM}

Enclosed please find my check for $\$$ for copies

Please bill my office \$ for copies.

$\begin{array}{rcc}\text { Bulk Orders } & \begin{array}{c}\text { APSA Departmental } \\ \text { Service Member }\end{array} & \text { Non-Member } \\ 10 \text { copies } & \$ 3.00 & \$ 4.00 \\ 50 \text { copies } & 12.50 & 17.50 \\ 100 \text { copies } & 20.00 & 30.00\end{array}$

(Single copies are available for fifty cents each, prepaid.)

SEND TO

\section{Zip}

Return this form with check to: Departmental Services Program

American Political Science Association

1527 New Hampshire Avenue, N.W.

Washington, D.C. 20036 


\section{RECENT BOOKS FROM HARPER \& ROW}

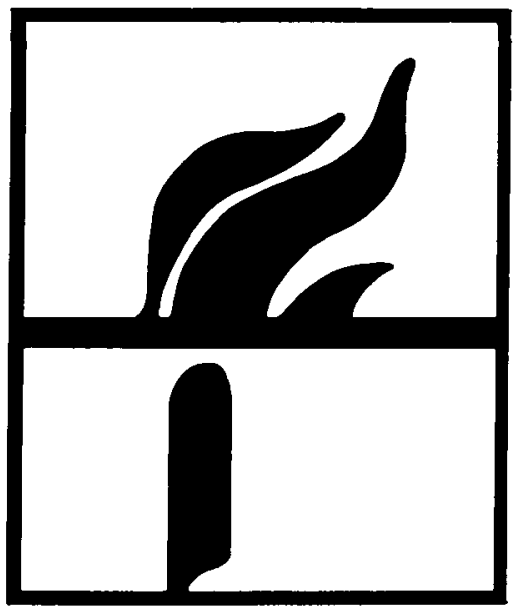

\section{THE GOVERNANCE}

\section{OF BRITAIN}

By Harold Wilson. An outstanding contribution to the literature of political life in the 20th century which analyzes: the role of the office of Prime Minister from Walpole to the present day; the workings of the Cabinet; the management of a modern nation. $\$ 10.00$ (Coming in April)

UNCERTAIN GREATNESS Henry Kissinger and American Foreign Policy By Roger Morris. A former National Security Council staff member has written a critical analysis of both the brilliance and the blunders of the Kissinger years that is sure to spark nationwide controversy. $\$ 10.00$

\section{THE CUBAN REVOLUTION}

By Hugh Thomas. A paperback edition including roughly half of the author's monumental Cuba: The Pursuit of Freedom, plus a new introduction, and extensive analysis of Cuban history since 1952.

Illustrated. $\$ 8.95$ (Coming in April) 


\section{CROOKED PATHS}

\section{Reflections on Socialism, Conservatism, and the Welfare State}

By Peter Clecak, University of

California, Irvine. In a stunning reconsideration of American culture and politics, the author of Radical

Paradoxes examines bourgeois tradition in light of the decline of affluence as a central American expectation. $\$ 10.95$

\section{THE VANISHING WHITE MAN}

By Stan Steiner. In this eloquent sequel to The New Indians, Steiner says that it is the white man, and not the Indian, who will one day vanish from the American West, choked by greed and smog in a land the Indians struggled so long to conserve. Illustrated. $\$ 10.95$

\section{ASSASSINATION IN AMERICA}

By James McKinley. A comprehensive analysis of political assassination in America, viewed from both historical and psychological perspectives.

Illustrated. $\$ 10.95$

\section{GLOBAL FRACTURE The New International Economic Order}

By Michael Hudson. With the world entering an era of regional economic blocks, each with its own currency and trading system, a leading economist elaborates U.S. diplomatic and economic strategy in light of this new regionalism. $\$ 12.50$ (Coming in April)

\section{TRIUMPH IN PARIS}

The Exploits of

\section{Benjamin Franklin}

By David Schoenbrun. "Scholarship, grace and wit all attend this story of America's first and greatest diplomat and his mastery of the world crisis that brought this country into being" - Theodore H. White. $\$ 15.00$

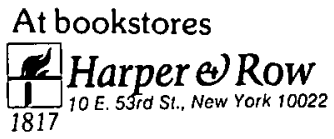




\section{NEWW TRTLES 听。}

\section{AMERICAN POLITICS - Making Public Policy: Studies in American Politics}

John Brigham, University of Massachusetts, Amherst

1977

Paper

432 pages

In this supplementary text for courses in American government and politics, students learn how public policy is made through exposure to original source materials - documents and letters, speeches, statutes, interviews and reports on critical and controversial issues.

\section{American Politics: Policies, Power and Change, Third Edition}

Kenneth M. Dolbeare, University of Massachusetts, Amherst Murray J. Edelman, University of Wisconsin 1977 Paper

576 pages

This introduction to the institutions and processes of American government helps students develop the critical and analytical skills they need (1) to understand their political system more clearly; (2) to act more effectively to gain their ends in politics; (3) to become independent thinkers - making responsible judgments about the workings and actions of the U.S. political system and alternatives.

\section{The American Way: An Introduction to U.S. Government and Politics}

James T. Myers, University of South Carolina

February 1977

Cloth

576 pages

This combination text and reader features discussions of the essentials of American government smoothly integrated with more than 30 conversations the author conducted with prominent national figures to provide students with an inside look at the way the American political system operates.

\section{A Preface to Politics, Second Edition}

David Schuman, University of Massachusetts, Amherst

February 1977

Paper

256 pages

The main purpose of the book is to challenge readers to discover for themselves what it means - in political terms - to live in America today. The author's wit, colorful style, and profound insights have tremendous personal appeal for college students.

\section{URBAN AMERICA - \\ Urban America and Public Policies}

Marian Lief Palley, University of Delaware

Howard A. Palley, University of Maryland

February 1977

Paper

288 pages

The central theme of this text is that current urban problems affect the entire fabric of American society and can only be solved through national legislative intervention supported by state and local governments. This concept is then developed through in-depth explorations of urban crises (i.e. in education, public welfare, the environment, health, and transportation). 


\section{POLITICAL ECONOMY - \\ The Politicized Economy}

Michael H. Best, University of Massachusetts, Amherst

William E. Connolly, University of Massachusetts, Amherst

1976

Paper

208 pages

THE POLITICIZED ECONOMY introduces students of political economy and public policy to a radical interpretation of the American system. The text examines major topics such as inflation, unemployment, inequality, environmental control, the structure of work life, and the crisis of the states, which are essential for an understanding of the American political economy.

\section{Power and Politics in the U.S.:}

\section{A Political Economy Approach}

G. David Garson, Tufts University

March 1977

Paper

368 pages

POWER AND POLITICS IN THE UNITED STATES gives introductory students of politics or American government a political economic framework for analyzing distribution of power and its political implications in the United States.

\section{Problems in Political Economy An Urban Perspective, Second Edition}

David M. Gordon, New School for Social Research

February 1977

Paper

528 pages

Considers current urban economic problems from a radical perspective. Selections by leading economists and original introductions develop the basic theses: that urban problems have developed from the structure of our economic institutions and that these institutions must be changed to solve such problems.

\section{CORPORATE POWER -}

\section{Corporations and Political Accountability}

Mark V. Nadel

1976

Paper

265 pages

Attention both to current-interest topics (consumer protection, campaign contributions including Watergate activities, antitrust action, corporate secrecy, etc.) and to more standard topics (interest groups, lobbying, regulatory agencies, etc.) gives students a balanced, multifaceted perspective on corporate power.

\section{COMING THIS FALL -}

\section{American Foreign Policy: A History}

Thomas G. Paterson, University of Connecticut

J. Garry Clifford, University of Connecticut

Kenneth J. Hagan, U.S. Naval Academy

Fall 1977

Cloth

600 pages est.

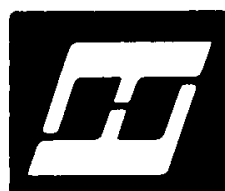

For details or sample copies, call us toll free: 800-225-1388.

In Massachusetts, call collect: 617-862.6650, ext. 1344.

D.C. Heath and Company

A Raytheon Company

Home Office: 125 Spring Street, Lexington, Massachusetts 02173

Sales Offices: Atlanta, Ga. 30318 / Rockville, Md. 20852 / St. Louis, Mo.

HEATH

63132 / San Antonio, Texas 78217 / Novato, Calif. 94947 / Toronto, Ontario M5H $1 \mathrm{S9}$ 


\section{The Troubled Détente}

By ALBERT L. WEEKS. This is the first close study of the events and processes which led to the present "cold peace" between the world's two major powers. It penetrates the intricacies of the Russian ideology of detente, from its precedents in Leninist theory, to its implementation in the post-Stalin regimes of Khrushchev and Brezhnev.

190 pages, $\$ 10.00$

\section{The Crisis of Democracy}

Report on the Governability of Democracies to the Trilateral Commission

By MICHEL CROZIER, SAMUEL P. HUNTINGTON, AND JOJI WATANUKI. This incisive work examines the problems of government in Europe, Japan and the U.S., offering expert views on the present and future governability of democracies. 220 pages, $\$ 12.00$ cloth $\$ 4.95$ paper

Hunger, Politics and Markets

The Real Issues in the Food Crisis
Edited by SARTAJ AZIZ, with a foreword by Barbara Ward. This is a comprehensive examination of one of today's most urgent global issues from a variety of viewpoints based on the Rome Forum, a two-day colloquy which preceded the World Food Conference in November, 1974.

"...literate, scholarly, written by well-informed insiders with ...comments by hyper-intelligent observers."-Food Policy 130 pages, $\$ 8.95$ cloth $/ \$ 4.95$ paper

\section{The American Presidency}

The Dilemmas of Shared Power and Divided Government
By ERNEST S. GRIFFITH. A realistic analysis of the American executive institution, surveying administrations of the last 40 years, and examining the institutional presidency in its relation to state and local governments as well as foreign nations and the media.

241 pages, $\$ 13.50$ cloth $\mathbf{\$} 4.95$ paper

Also by the same author, with Francis R. Valeo: CONGRESS: Its Contemporary Role, 288 pages, $\$ 15.00$ cloth $\$ 5.95$ paper

\section{Forthcoming:}

Government Secrecy in Democracies
Edited by ITZHAK GALNOOR. In the 16 original essays written for this volume, authors from nine countries examine the cultural, social and political contexts of government secrecy to see how "open" democracies really are.

April, 300 pages, $\$ 12.50$

\section{Two Hundred Years of American Foreign Policy}

A Council on Foreign Relations Book
Edited by WILLIAM P. BUNDY. Commissioned by Foreign Affairs magazine to celebrate the Bicentennial, this is a volume of distilled insights into the core questions of American foreign policy. Felix Gilbert, the late Alastair Buchan, George Kennan, John Paton Davies, Charles Kindleberger, Gordon Craig, and Abraham Lowenthal provide controversial and thought-provoking essays on the events of the past and the prospects for the future.

May, 368 pages, $\$ 15.00$ 


\section{FREEDOM AND THE COURT \\ Civil Rights and Liberties in the United States \\ Third Edition}

Henry J. Abraham, University of Virginia. $\square$ The Third Edition of this well-known text articulates the role of the United States Supreme Court in its continuing endeavor to identify and justify the lines and limits that our democratic society imposes in an effort to reconcile the rights of individuals and society. Particular emphasis is placed on major issues of public law, such as freedom of expression, racial and political equality, criminal justice, and religion. Analysis and evaluation of leading Court decisions is offered.

1977

$480 \mathrm{pp}$.

cloth $\$ 17.95$

paper $\$ 5.00$

\section{KARL MARX READER}

Edited by David McLellan, University of Kent. $\square$ This comprehensive account of the thought of Karl Marx includes material not previously published in English or available in popular volumes of Marx readings. The chronological arrangement of the selections emphasizes the development of Marxian thought. An introduction and bibliography is provided for each extract as well as a general bibliography and a full index for the book as a whole.

Spring 1977

$752 \mathrm{pp}$

cloth $\$ 12.00$

paper $\$ 6.00$

\section{MEDIA, POLITICS, AND DEMOCRACY}

Bemard Rubin, Boston University. $\square$ In this analysis of mass communications developments in the United States, the author emphasizes political and social consequences of current trends. He demonstrates the extent to which the future of democracy itself is tied to the mass communications industries. Among the print and electronic media topics treated at length are communications objectivity and responsibility, violence in the media, governmental controls and intimidations, public access, and the media and elections. (Reconstruction of Society Series) 1977 $208 \mathrm{pp}$.

cloth $\$ 8.00$

paper $\$ 4.00$

\section{SECRECY AND FOREIGN POLICY}

Edited by Thomas M. Franck, New York University; and Edward Weisband, State University of New York, Binghamton. $\square$ Leading legislators, policy-makers, lawyers, and journalists probe the delicate balance between the people's right to know and the government's need for confidentiality in a comparative discussion of the issues in the United States, Canada, and the United Kingdom. "A collection of two dozen sensible, anecdote-filled, provocative and often insightful papers.... It is hard to imagine what more could have been profitably included in this volume."-William D. Rogers, Assistant Secretary of State for Inter-American Affairs in Virginia Journal of International Law.

1974 (paper, 1976)

480 pp. cloth $\$ 15.95$ paper $\$ 4.00$

Prices and publication dates are subject to change.

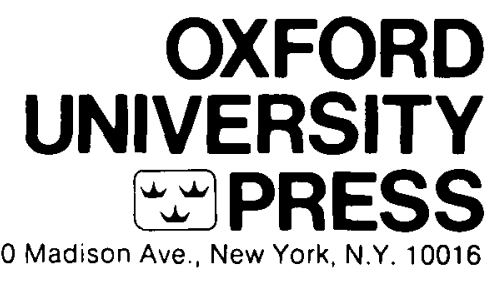




\section{OXFORD \\ UNIVERSITY \\ PRESS}

\section{Oxford Paperbacks}

\section{UNEQUAL JUSTICE}

Lawyers and Social Change in Modern America

Jerold S. Auerbach, Wellesley College. $\square$ According to Professor Auerbach, justice in the United States has been distributed according to race, ethnicity, and wealth, rather than need. "A powerful and well-documented indictment of the elite bar's failure to live up to the trust that has been bestowed upon it by our system of justice."-New York Times Book Review 1976

$416 \mathrm{pp}$.

$$
\text { A Galaxy Book (1977) }
$$

paper $\$ 3.95$

\section{THE ROLE OF THE SUPREME COURT IN AMERICAN GOVERNMENT}

Archibald Cox. $\square$ Reflecting upon Supreme Court decisions in light of recent events, Archibald Cox analyzes these decisions within their historical context. "It is lucid and informed and Cox brings to it a scholar's clarity and a participant's passion. His love for the law and for the American system of government lights every paragraph."-Boston Globe. "Lucid and gracefully written."- Harvard Law School Bulletin

$1976 \quad 128$ pp. A Galaxy Book (1977)

paper $\$ 1.95$

\section{TOWARD A PLANNED SOCIETY} From Roosevelt to Nixon

Otis L. Graham, Jr., University of California, Santa Barbara. $\square$ "I am delighted that Toward a Planned Society appears at this time.... Otis Graham, respected historian of progressive efforts in American society and government during the twentieth century, does an effective job of showing us where we stand today."

- Senator Hubert $\mathrm{H}$. Humphrey

$1976 \quad 382 \mathrm{pp}$. A Galaxy Book (1977)

paper $\$ 3.95$

\section{SOVIET FOREIGN POLICY 1962-1973} The Paradox of Super Power

Robin Edmonds. $\square$ "A careful and judicious description, year by year and area by area, of the policy of military buildup and detente diplomacy. As of now, the best book on the subject.'-Foreign Affairs. "This book is 'must' reading for any diplomat, scholar, or ordinary citizen who is sincerely interested in the present directions of Soviet foreign policy."-Christian Science Monitor

1975224 pp.; 5 maps A Galaxy Book (1977) paper $\$ 2.95$ 


\section{ENGLISH-SPEAKING SOUTH AFRICA TODAY}

\section{Proceedings of the National Conference, July 1974}

Edited by André de Villiers. $\square$ The eighteen papers collected here consider the contribution of the English-speaking South African to the development of the country and discuss such topics as public affairs, population and community, the economy, religion, education, language and literature, and the media.

1976

396 pp.; 28 tables

\section{THE SOUTH AFRICAN ECONOMY}

\section{Fourth Edition}

D. Hobart Houghton. $\square$ An authoritative introduction to the South African economy for historians, political scientists, and sociologists as well as economists, this text has been extensively revised and updated to include the oil war, the collapse of the gold price, and the devaluation of South Africa's currency.

$1976 \quad 328$ pp.; 17 figs.; 25 tables; map

\section{PUBLIC POLICY AND THE SOUTH AFRICAN ECONOMY}

Essays in Memory of Desmond Hobart Houghton

Edited by M. L. Truu. $\square$ This volume in memory of Professor Hobart Houghton contains twelve essays which treat the theme of public policy in economics and the pressing problems confronting the South African economy today from both a practical and theoretical point of view.

1976

224 pp.; plate; figs.

$\$ 14.25$

\section{MIGRATION IN POST.WAR EUROPE Geographical Essays}

Edited by John Salt and Hugh Clout. $\square$ Concentrating on long-distance moves, these six essays examine the different types of migration that have occurred in Europe since the last war. Each essay deals with a particular migration theme in Western Europe-rural-urban migration, inter-urban migration, international migration. 1976

\section{THE GOVERNMENT OF INDIA AND REFORM}

\section{Policies towards Politics and the Constitution 1916-1921}

P.G. Robb. $\square$ Using unpublished official and private sources, Dr. Robb analyzes two main areas of British policy in India during the period of the First World War: the role of the India Government in the making of the Constitution of 1919, and the shifts in the Government's general strategy towards Indian politics and agitation.

(London Oriental Series)

1977

$384 \mathrm{pp}$. 


\section{HIGH AND LOW POLITICS: INFORMATION RESOURCES FOR THE 80's}

Anthonv G. Oettinger and William H. Read, Harvard University and Paul J. Berman (Program on Information Resources Policy, Harvard University)

These essays trace the politics, economics and technology of telecommunications pricing and costing policy and their impact on current communications policy; the interaction of old legal doctrines with newly combined computer and communications technologies and how these will affect FCC policy; the rapid growth of international telecommunications and its use in high and low politics as an instrument for policies shaping global interdependence.

In preparation

ca. $\$ 16.00$

\section{JURY SELECTION PROCEDURES}

Our Uncertain Commitment to Representative Juries Jon Van Dyke, School of Law, University of Hawaii, Manoa

A critical investigation of the nation's jury system based on data collected from the federal courts and a large number of state jurisdictions. Mr. Van Dyke concludes that current procedures of jury selection fall significantly short of producing juries representative of all segments of the population and recommends reforms for overcoming discriminatory practices.

$\$ 15.00$

\section{A GUIDE TO COURT SYSTEMS}

Fannie J. Klein, New York University School of Law and the Institute of Judicial Administration

Published in five earlier editions by the Institute of Judicial Administration, this enlarged edition of the guidebook covers the structure and operations of federal, state and local courts. Useful to attorneys, law students, court administrators, paralegals and researchers, this up-to-date book offers methods for conducting legal research and for gaining access to appropriate library materials. It includes a bibliography and extensive glossary of legal terms.

ca. $\$ 15.00$

\section{BANKERS AND BORDERS}

The Case of the American Banks in Britain

Janet Kelly, Center for International Affairs, Harvard University

Bankers and Borders addresses the question of international finances as an area of corporate expansion by examining both the economic and political aspects of the growth of American banking in Britain and by assessing the consequences of that growth for Britain and the United States. It is also a thoughtful analysis of the role of public policy in shaping corporate action.

In preparation

ca. $\$ 15.00$

\section{HEALTH ASSOCIATIONS AND THE DEMAND} FOR LEGISLATION

The Political Economy of Health

Paul J. Feldstein, Bureau of Hospital Administration. University of Michigan

How interest groups representing health manpower professions and nonprofit health institutions use government intervention to reach goals which they cannot achieve in the marketplace. Includes a political economy model useful for predicting types of legislation health interest groups are likely to support or oppose.

In preparation

ca. $\$ 18.00$

\section{LIMITS OF JUSTICE}

Courts' Roles in Desegregation of Education Litigation

Edited by Howard I. Kalodner, Institute of Judicial Administration

These case studies of recent school desegregation suits examine detaits in the formulation and implementation of relevant judicial decrees, the aspects of the decrees most difficult to administer, and the variables which affect the success or failure of a com. munity's attempt to integrate its schools.

In preparation

ca. $\$ 20.00$

\section{THE PUBLIC INTEREST IN GOVERNMENT LABOR RELATIONS}

Richard P. Schick, National Civil Service League and Jean J. Couturier, Public Management Program, Northwestern University

A weal th of theoretical concepts and empirical information, these studies of state and local labor negotiations emphasize the roles of interested parties their access to and influence upon - the political decision-making process.

In preparation

ca. $\$ 16.50$

\section{CITIZEN COMMITTEES}

A Guide to Their Use in Local Policymaking

Joseph Lee Rodgers, Jr., University of Ok/ahoma

Designed to assist public administrators and others responsible for creating or participating on citizen committees. Using brief explanations and illustrations, it sets forth the types, purposes, advantages and disadvantages, guiding principles, and organizational characteristics of citizen committees. In preparation

ca. $\$ 10.00$

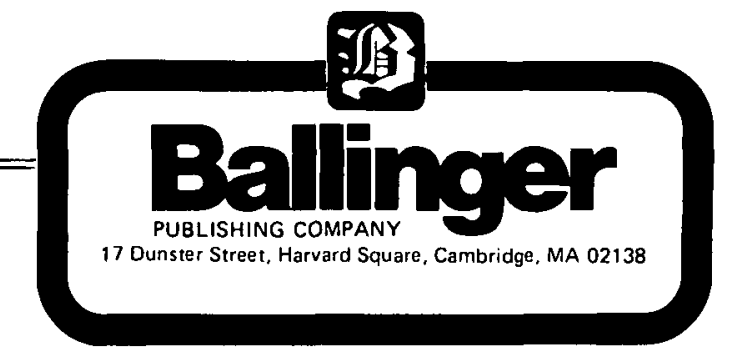




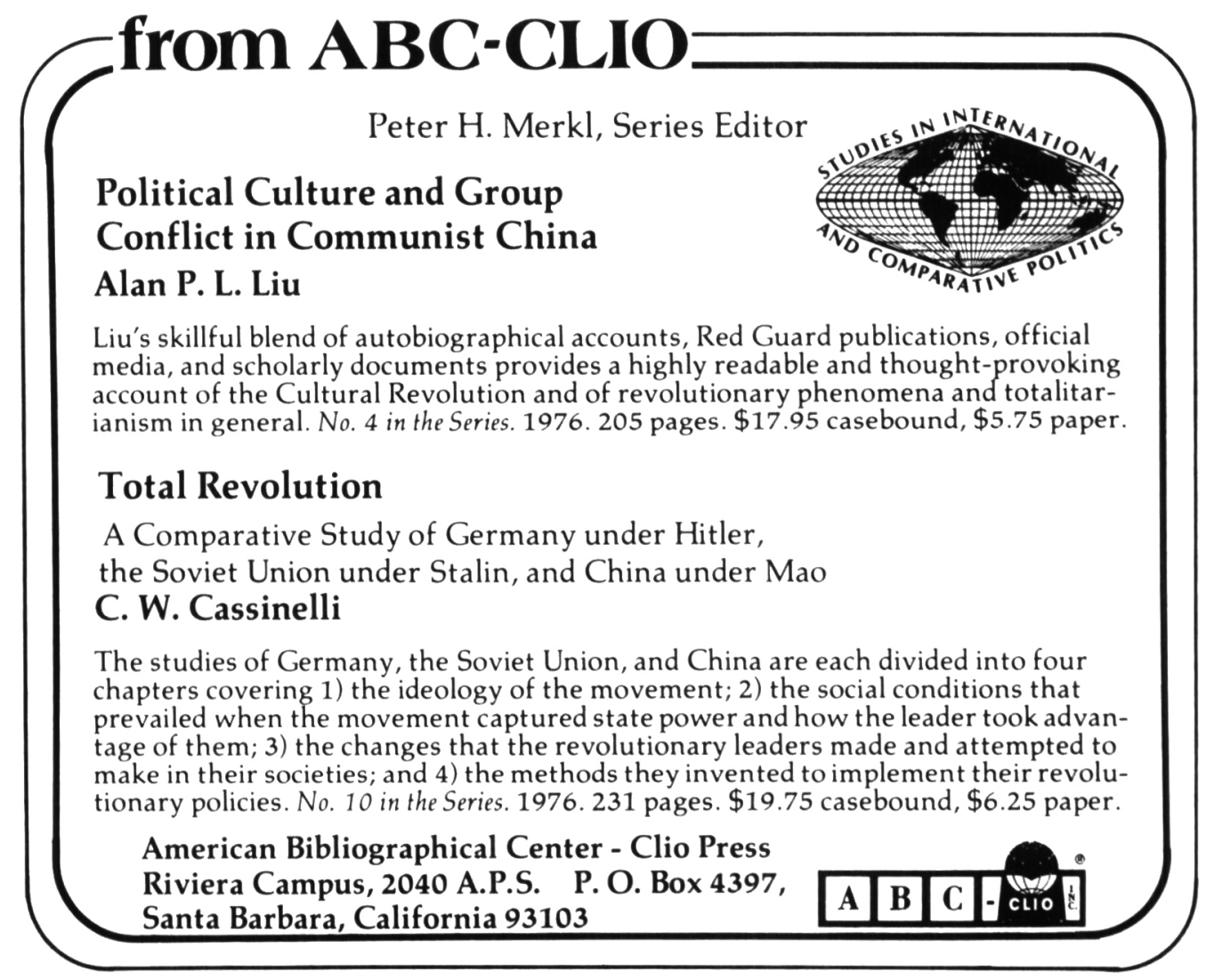

\section{"Must reading for all concerned with the crime problem."-Choice}

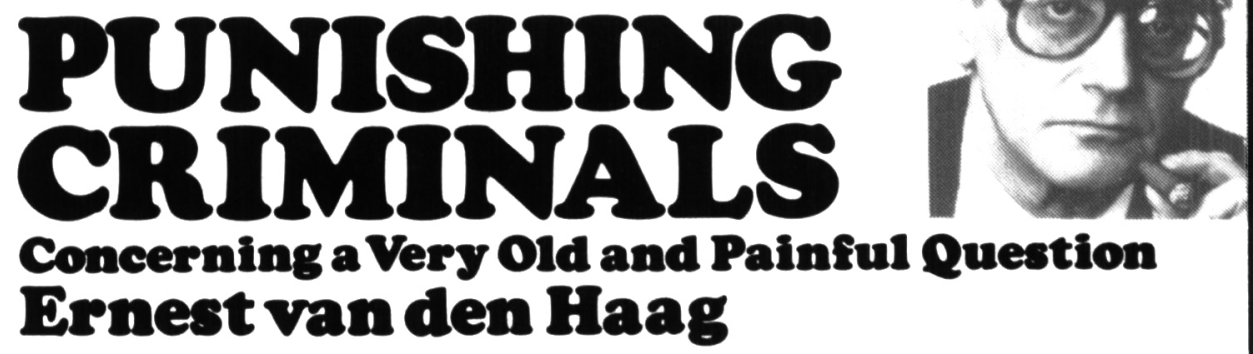

"PUNISHING CRIMINALS is likely to assume a central place in this reinvigorated debate over the direction in which the criminal justice system should proceed... Van den Haag marshals his philosophical arguments with formidable resourcefulness, not to mention forcefulness....[His] willingness to consider the seemingly outrageous and to reconsider the conventional are what make PUNISHING CRIMINALS so worth reading and deliberating.' -Political Science Quarterly

"Desperately needed...well argued and the facts marshalled are overwhelming.'-W. V. Quine, Harvard University $\$ 11.50$ 
Students, professors, and those interested in the study of politics and government are invited to become members of the AMERICAN POLITICAL SCIENCE ASSOCIATION.

\section{JOIN APSA}

\section{Membership includes:}

The American Political Science Review-quarterly journal of scholarly articles and book reviews in political science;

PS-quarterly journal of association news and articles of professional concern;

DEA News-quarterly newspaper on educational materials and methods;

Opportunity to register in the APSA Personnel Service-currently lists the largest number of political science teaching and research positions.

Attend the APSA Annual Meeting, September 1-4, 1977, Washington, D.C.

Name

Mailing Address

Zip

This is an application for membership. Upon receipt of this form we will mail you a membership card and begin a year's subscription to the American Political Science Review and $P S$.

Student

Annual:

If your annual income is under $\$ 12,000 \ldots \ldots \ldots \ldots \ldots \ldots \ldots \ldots \ldots \ldots$

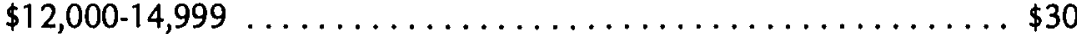

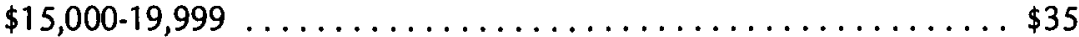

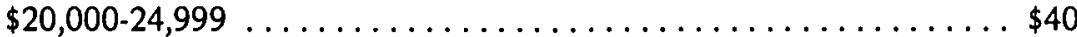

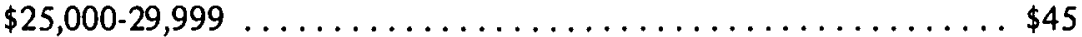

Over $\$ 30,000$

Add $\$ 2$ for foreign postage.

Please send with remittance to:

Membership Secretary

AMERICAN POLITICAL SCIENCE ASSOCIATION

1527 New Hampshire Avenue, N.W.

Washington, D.C. 20036 


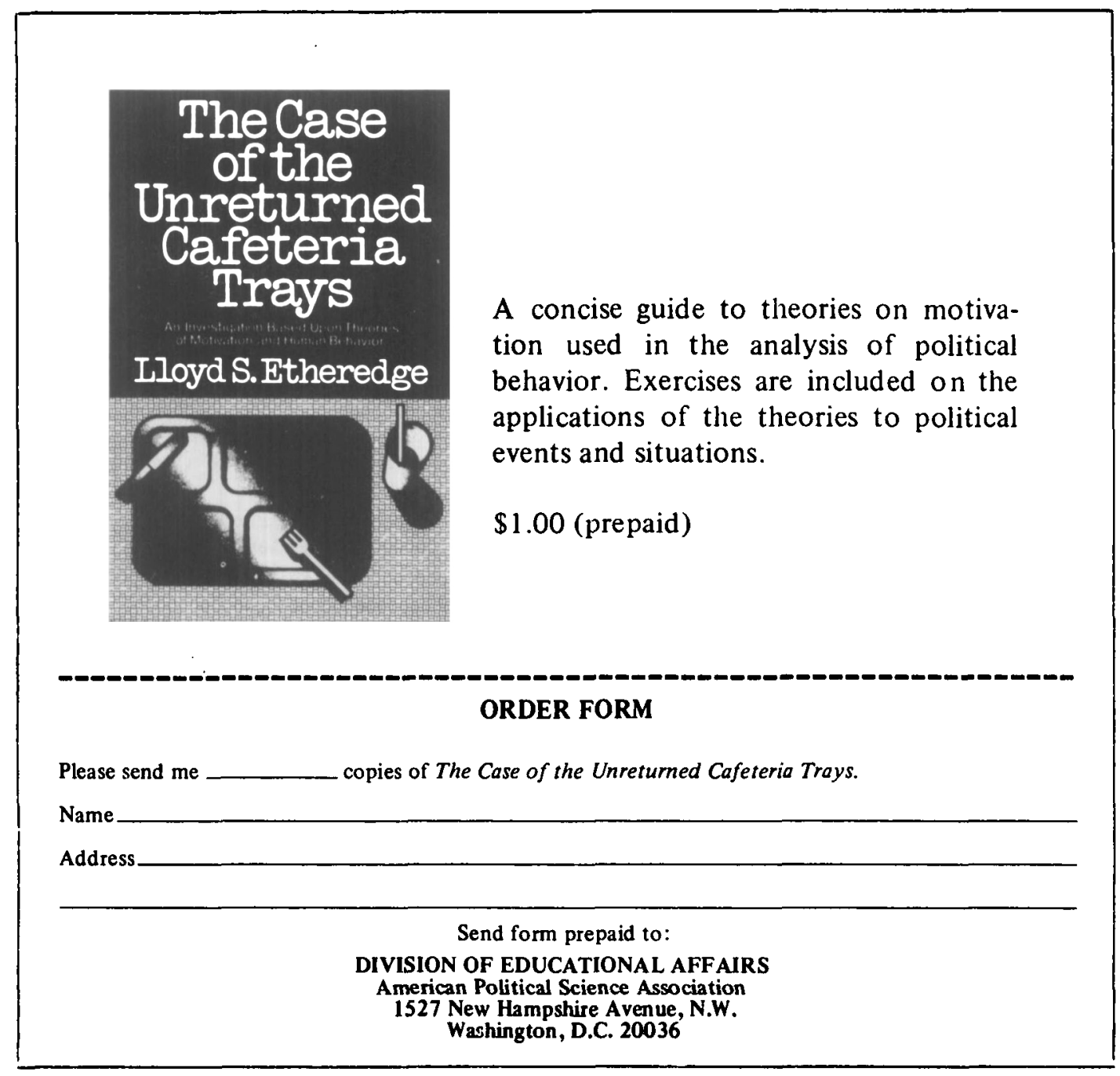

The American Political Science Review 
"The CQ Gulde to Congress is not only an invaluable historical reference for students of Congress, but an indispensable daily working tool in my congressional office and in the House Republican Conference which I chair. The new edition is a critical update, covering as it does the jarring events and landmark accomplishments of the last halfdecade: the Watergate and intelligence inquiries and revelations, the impeachment proceedings, the warpowers and budget reforms, and the major power shifts and institutional changes in the Congress over the past few years."

-John B. Anderson (R III.)

Chairman, House Republican Conference
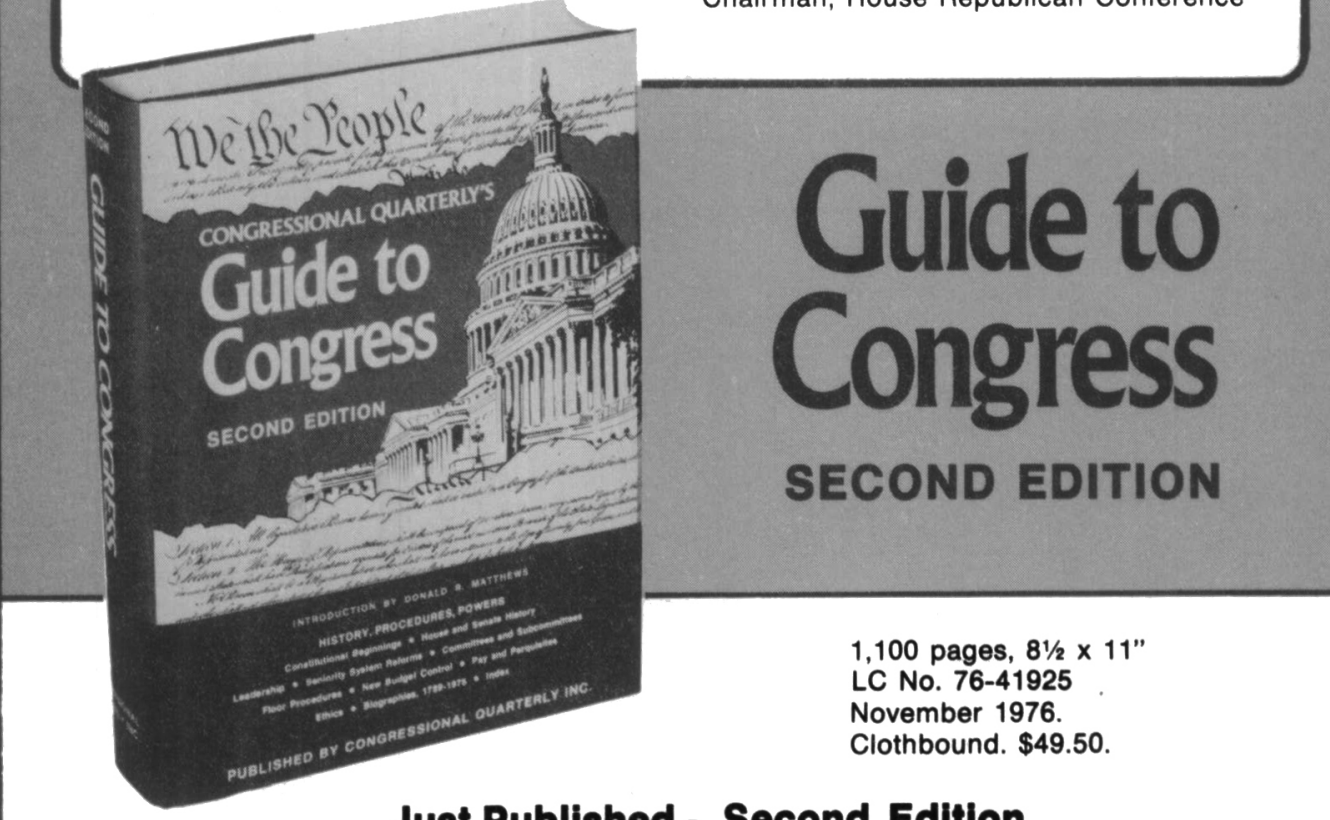

SECOND EDITION

1,100 pages, $8 \frac{1}{2} \times 11$ "

LC No. 76-41925

November 1976.

Clothbound. \$49.50.

\section{Just Published - Second Edition}

Announcing publication of a second edition of the book widely accepted as the reference on the U.S. Congress. This is no coffee-table edition-Guide to Congress, Second Edition belongs in every public library, college and high school in the country.

The first edition, published in 1971, was selected by the American Library Association as one of the "Outstanding Reference Books of 1971." The late Paul H. Douglas, former senator from Illinois, wrote, "It is a magnificent work, the best of its kind-reliable, accurate and fair."

But new legislation and changes in procedure prompted by Watergate, Vietnam and an increasingly Democratic Congress have outdated this standard reference work-hence this extensively revised second edition.

All the recent reforms are included plus scholarly but easily understandable explanations of how Congress works, its powers and the pressures upon it. Charts, a 225-page Appendix and a 45page Index.

\section{CONGRESSIONAL QUARTERLY INC.}

Box 70, 1414 22nd St., N.W., Washington, D.C. 20037

Please mail __ copies at $\$ 49.50$ each of Gulde to Congress.

Enclose payment and $\mathrm{CQ}$ will pay shipping

Mall to 


\section{New Editions of Well-Known Texts .............. \\ Thoroughly updated with approximately one-third new cases CIVIL LIBERTIES UNDER THE CONSTITUTION THIRD EDITION \\ M. Glenn Abernathy \\ This comprehensive and cohesive treatment of the constitutional aspects of American civil liberties continues to cover a substantially greater number of cases than other available texts. Assuming no prior knowledge of the subject, the author interweaves commentary and explanation with 126 carefully edited case-cuttings. Tentative: 608 pages; \$11.50. January 1977. ISBN 0-06-040136-2. \\ The most widely used text in undergraduate and graduate public administration courses \\ MODERN PUBLIC ADMINISTRATION FOURTH EDITION \\ Felix A. Nigro and Lloyd G. Nigro \\ No other text so succinctly covers the theoretical and conceptual elements of the field and then so clearly relates these aspects to concrete examples from present practices and current relationships. The new Fourth Edition is thoroughly revised to reflect recent developments in the theory, practice, and problems of public administration. 491 pages; $\$ 13.95$. January 1977. ISBN 0-06-044843-1. New!- Instructor's Manual. \\ Emphasizes principles and broad methodologies rather than detailed procedures \\ PUBLIC PERSONNEL ADMINISTRATION SEVENTH EDITION \\ O. Glenn Stahl \\ "The great majority of U.S. public personnel managers and many abroad have been brought up on one or another edition of this classic text."-Public Personnel Review/The Seventh Edition gives increased attention to unionization, relations between public management and unions, issues of equal opportunity and affirmative action, and environmental considerations. 575 pages; $\$ 16.95$. August 1976 . \\ ISBN 0-06-046387-2. \\ A provocative treatment of today's major domestic political issues \\ CHALLENGE AND DECISION POLITICAL ISSUES OF OUR TIME, FIFTH EDITION \\ Reo M. Christenson 244 pages; $\$ 5.50 /$ paper. August 1976. ISBN 0-06-041267-4.

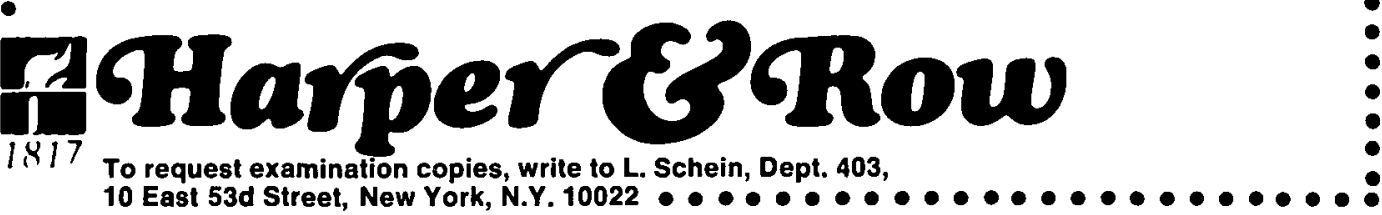




\section{If you're looking for more in politics, look here.}

Roth/Wilson

The Comparative Study

\section{of Politics}

David F. Roth, Frank L. Wilson

both of Purdue University

448 pages, 1976.

Roth and Wilson introduce the major concepts and theories of comparative politics and political science. Each chapter discusses a specific topic and presents examples from each of six countries within the chapter.

\section{Morlan}

\section{American Government}

\section{Policy and Process, Second Edition}

Robert L. Morlan, University of Redlands

464 pages, paper, with Instructor's Manual. 1975.

In a concise introductory text, Morlan emphasizes how the political system actually works, analyzes its problems, and presents significant cases of domestic and international policy. Students become personally involved in decision-making roles.

\section{Smith/Johnson/Paulsen/Shocket}

\section{Political Research Methods}

\section{Foundations and Techniques}

Barbara Leigh Smith, Universityof Nebraska

Kart F. Johnson, University of Missouri

David W. Paulsen, University of Nebraska

Frances Shocket

352 pages. 1976.

The most comprehensive single text of its kind, Political Research Methods combines depth and breadth of coverage (including new techniques and methods) with explicit reference to political

science. Accurately presents current controversies.

\section{Deutsch}

\section{Politics and Government}

\section{How People Decide Their Fate}

\section{Second Edition}

Kart W. Deutsch, Harvard University

650 pages, with Instructor's Manual. 1974.

Deutsch emphasizes real-world politics. He presents basic concepts for analysis, focusing on six major political systems, and discusses the unfinished business of politics. For introductory political science courses.

\section{The Mexican Political System} Second Edition

L. Vincent Padgett, San Diego State University 272 pages, paper. 1976

\section{Public Administration}

Richard J. Stillman, II, Office of the Deputy Attomey General, U.S. Department of Justice

398 pages, paper. 1976.

\section{Victims of Groupthink}

\section{A Psychological Study of Foreign-Policy Decisions and Fiascoes \\ Irving Janis, Center for Advanced Study in the Behavioral Sciences, Stanford, California 277 pages, paper. 1972}

\section{The Politics of Violence: The New Urban Blacks and the Watts Riot}

David O. Sears, University of Calitomia, Los Angeles John B. McConahay, Yale University 244 pages, paper. 1973.

For adoption consideration, request examination copies from your regional sales office.

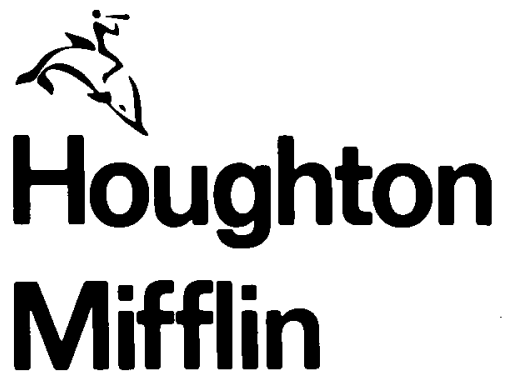

Atlanta, GA 30324 Dallas, TX 75235

Geneva, IL 60134 Hopewell, NJ 08525

Palo Alto, CA 94304 Boston, MA 02107 


\section{New and Forthcoming}

\section{from Lexington Books}

Decentralizing City Government

Allen Barton, Norman Fainstein, Susan Fainstein, Nathalie Friedman, Stanley Heginbotham, Joel Koblentz, Theresa Rogers, John Boyle, and Ronald Brumback, Columbia University

In Press Winter/Spring 1977

Political Science and School Politics

edited by Samuel K. Gove and Frederick M. Wirt, University of Illinois

A Policy Studies Organization Book

160 pp. $\$ 14.50$

The Pacific Quest

Endel-Jakob Kolde, University of Washington

176pp. $\$ 14.00$

The Jurocracy

Donald L. Horowitz

In Press Winter/Spring 1977

International Payoffs

Yerachmiel Kugel and Gladys W. Gruenberg, St.

Louis University

In Press Winter/Spring 1977

The British MP, 1945-1975

Colin Mellors, University of Bradford

In Press Winter/Spring 1977

The British Right

edited by $\mathbf{N}$. Nugent, Manchester Polytechnic, and R. King, Huddersfield Polytechnic

In Press Winter/Spring 1977

\section{Coercion to Compliance}

Harrell R. Rodgers, Jr., and Charles S. Bullock, III, The University of Houston

208 pp. $\$ 13.00$ (cloth) $\$ 6.95$ (paper)

Fiscal Management and Planning in Local Government

James C. Snyder, University of Wisconsin

In Press Winter/Spring 1977

The Economics of Local Public Service Consolidation

Thomas G. Cowling, A. G. Holtman, State University of New York

256pp. $\$ 14.50$

Foreign Economic Policies of Industrial States edited by Wilfrid L. Kohl

In Press Winter/Spring 1977
The Policy Vacuum

Robert N. Spadero, The Chinese University of

Hong Kong; Thomas R. Dye, Florida State

University; Robert T. Golembiewski, University

of Georgia; Murray S. Stedman, Temple Univer-

sity; and L. Harmon Ziegler, University of

Oregon

224 pp. $\$ 17.00$

Using Social Research for Public Policy-Making edited by Carol H. Weiss, Columbia University A Policy Studies Organization Book

In Press Winter/Spring 1977

Marine Policy

John King Gamble, The Pennsylvania State

University

In Press Winter/Spring 1977

Productivity in Local Government

Frederick O'R. Hayes

In Press Winter/Spring 1977

The Environmental Syndrome

edited by Leon N. Lindberg, The Brookings Institution

In Press Spring 1977

Toward a National Health Policy

Kenneth M. Friedman, Purdue University; Stuart H. Rakoff, United Mine Workers Health and Retirement Fund

In Press Winter/Spring 1977

Write for full descriptions and a complete catalog.

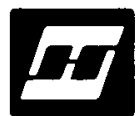

Lexington Books

D.C. Heath and Company

125 Spring Street

HEATH Lexington, Massachusetts 02173 


\title{
Bias in the News
}

Network Television Coverage of the 1972 Election Campaign

By C. Richard Hofstetter. Just before the 1972 presidential election, there was instituted, under sponsorship of the American Enterprise Institute for Public Policy, an innovative project designed to investigate systematically a variety of commonplace assertions about the existence of bias in national television coverage of political and social events. The results of that survey and study are presented for the first time in a volume that provides a valuable corrective to the easy assumptions and gross oversimplifications that have been the basis for the passionate asseverations of advocates and critics on both sides of the debate.

$\$ 13.75$

\section{Electing Black Mayors}

\section{Political Action in the Black Community}

By William E. Nelson Jr., and Philip J. Meranto. A study of the successes and failures in the exercise of black power that uses a wide range of empirical data and advanced techniques of statistical analysis to demonstrate conclusively that factors other than sheer numbers, mere majority, and high geopolitical density serve to explain the election of such black candidates for mayor as Richard G. Hatcher, of Gary, Indiana, and Carl B. Stokes, of Cleveland.

$\$ 20.00$

\section{Cleveland}

\section{Confused City on a Seesaw}

By Philip W. Porter. An unsparing but affectionate political portrait, by the former executive editor of the Cleveland Plain Dealer, of the city that was to become, early in this decade, a kind of popular metaphor for the troubled American metropolis with its racial conflict, urban decay, damaged environment, rising crime, shrunken revenues, and disenchanted and irate citizens.

Illus. $\$ 12.50$

\section{The Politics of Business in California, 1890-1920}

By Mansel G. Blackford. An examination of three of California's more important basic productive industries - agriculture, oil, and lumber and three of its principal supportive businesses - banking, investment banking, and insurance-against the background of two major issues that cut across industry lines: the growing movement to bring about state regulation of railroads and public utilities, and the effort to effect tax reform.

\section{OHIO STATE UNIVERSITY PRESS}

\author{
2070 Neil Avenue, Columbus 43210
}




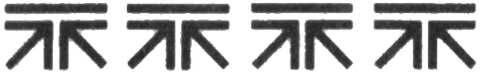

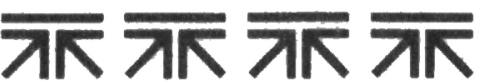

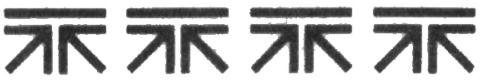 六 নার নার নার নার নার

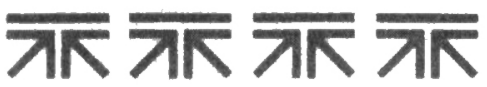 নার নার নার দার TOUCHSTONE}

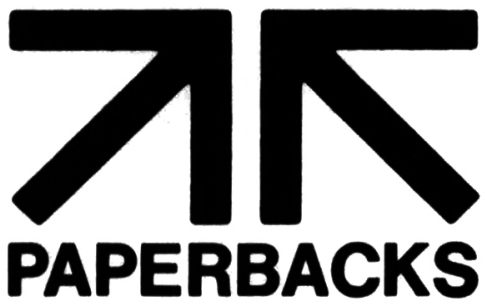

SIMON AND SCHUSTER 630 FIFTH AVENUE NEW YORK, N. Y. 10020

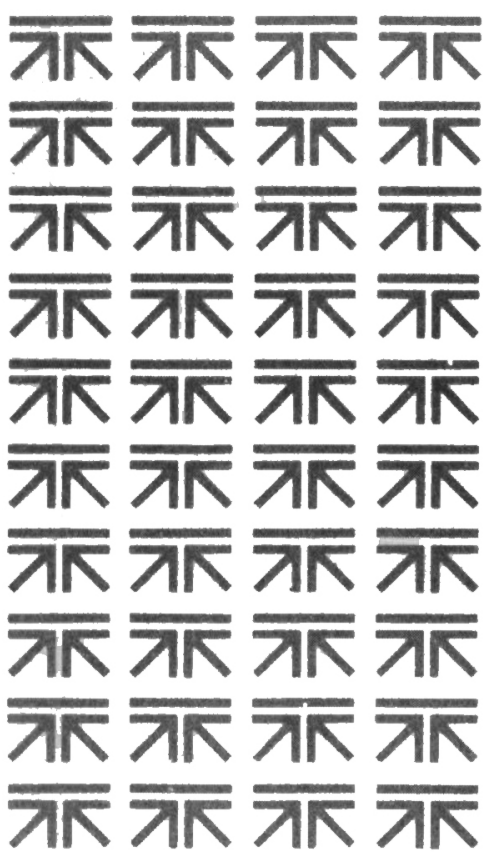

For complimentary examination copies and catalogs, write on your departmental letterhead to School and Library Services, address above. Include details on course in which you are considering using title requested, and advise us where you have seen announcement.

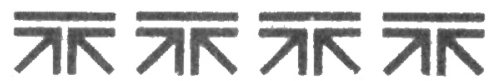

\section{Schrag, Peter}

TEST OF LOYALTY:

Daniel Ellsberg and the Rituals of

Secret Government

In this timely book Peter Schrag describes one of the most important legal constitutional confrontations of the decadethe Pentagon Papers trial. Focusing upon the central figure of Daniel Ellsberg, who renounced his role in the militaryindustrial complex and turned over copies of secret government papers to The New York Times, Peter Schrag explores the limits of the right to dissent and the use of civil disobedience. "Perhaps the most devastating thing about reading this book is its reminder of how rapidly we forgot the incidents it describes, and how badiy we need constant reminders of them. . . . Test of Lovalty cannot fail to help us recover a sense of moral outrage."-Robert McAfee Brown, New York Times Book Review. "A lucid journalistic description and analysis of the political trial of Daniel Ellsberg and Anthony Russo."Choice.

\section{$\square 22021 \$ 3.95$}

\section{Levy, Mark R., and Kramer, Michael S.}

THE ETHNIC FACTOR: How America's Minorities Decide Elections

The first comprehensive study of the way the hyphenated Americans vote, The Ethnic Factor examines the voting behavior of our sixty-five million ethnics: election by election, state by state, precinct by precinct. It debunks some of the most dearly held assumptions of our political and sociological "wisdom," and it demonstrates conclusively how and why the ethnics potentially hold the key to the political future of the United States. "The Ethnic Factor is far and away the best work ever done on ethnic voting patterns and ought to be read by anyone who is concerned with understanding American elections." -Andrew M. Greeley. $\square 21527 \quad \$ 2.95$

\section{Commager, Henry Steele \\ THE DEFEAT OF AMERICA: \\ Presidential Power and the National Character}

America's preeminent historian focuses here on the two major crises that have recently faced all Americans: the war in Vietnam and the misuse of presidential power. No other historian so skillfully makes us aware of how much America's past influences America's present. In doing so, Professor Commager, as always, challenges us to build a better future. $\square 21777 \quad \$ 2.95$

\section{Friedman, Lawrence $M$.}

\section{A HISTORY OF AMERICAN LAW}

A unique and comprehensive history of American law-its origins, substance, procedures, and growth. This National Book Award nominee makes clear the contrapuntal balance between law and the society it serves, demonstrating the extent to which modern law-and modern society-bear the imprint of the legal past. "This concise history is nothing less than superb. Designed for laymen, it is detailed enough to both interest the professional and provide depth, without resorting to the turgid prose of most lawyers' books. Friedman is at ease with fact, trend, theory, and policy and he writes well. Good bibliographical essay."-Choice. "The book is well documented and highly readable, and the author successfully shows that law changes with the times and is eternally new."Library Journal. "Professor Friedman's mature and reflective book will surely become a standard work in American legal history and likely will remain for many years the only general treatment of the subject."-James W. Ely, Jr., Vanderbilt Law Review.

$\square 21742$ Biblio., Index \$6.95 


\section{Important New Texts

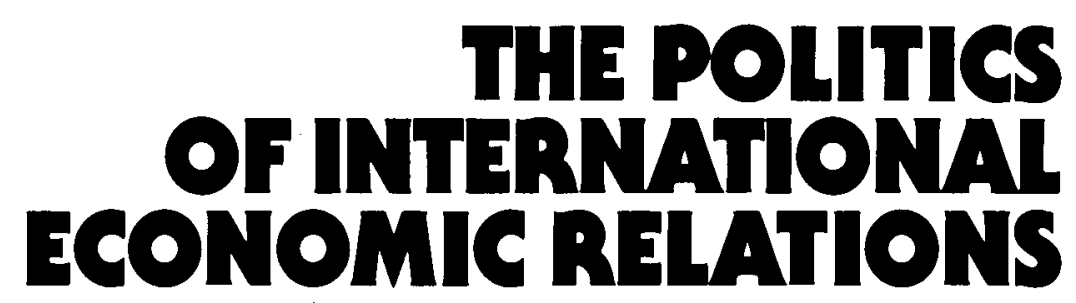

Joan Edelman Spero, Columbia University

- Ideally suited for courses on international relations, world politics, American foreign policy, or international organization.

- Focuses on the links between international economics and international politics, examining the economic interdependence of states and analyzing the key issues involved in the East-West and North-South systems of trade.

- Traces the development of international institutions and their response to the political management of international economic relations.

February approx. 300 pages paperbound, $\$ 4.95$ (tentative)

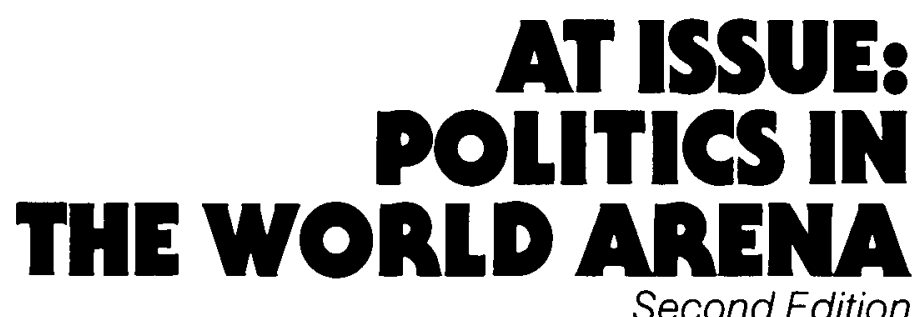

Steven L. Spiegel, University of California_Los Angeles

- A new, thorough revision of a best-selling text that has been hailed as:

"An excellent reader... a good supplemental text for courses in world politics."

- Elsworth P. Woods, Drake University

"Very good treatment of real issues. I am using it now and the students really enjoy it." -Walter Kivette, University of North Carolina

"Excellent in content, organization, and readability ... thought provoking and stimulating." -Sandy L. Royster, Wheaton College

- New to the second edition are twenty-eight lively articles on such current topics as the energy crisis and OPEC, terrorism, international intelligence, detente, the turmoil in Southern Africa and the Middle East, and arms limitation.

February approx. 380 pages paperbound, $\$ 5.95$ (tentative) 


\section{from St. Martin's Press}

\section{TECHNOLOGY AND MAN'S FUTURE}

Second Edition

edited by

Albert H. Teich, George Washington University

- A new, extensively revised edition of a book that was hailed as

"An important, provocative work, particularly useful in the study of change."

- Avtar Singh, East Carolina University

"In a class by itself as a selection of readings on the subject."

- Lester G. Hawkins, SUNY at Albany

- Organized to provide maximum flexibility, the articles include some of the most significant contemporary thought on the relationship between technology and society - the only book currently available that gives thorough coverage to the "limits of growth" debate and issues of assessment and control.

February approx. 300 pages paperbound, $\$ 4.95$ (tentative)

\section{TECHNOLOGY AND THE HUMAN CONDITION}

Bernard Gendron, University of Wisconsin at Milwaukee

- Provides a broad, comprehensive survey and synthesis of the major issues concerning the social role of technology.

- Drawing from disciplines in the humanities, social sciences and technology, the author weighs and discusses the various relevant perspectives on the issues, making them highly accessible to undergraduate students.

January approx. 274 pages paperbound, $\$ 4.95$ (tentative)

For complimentary examination copies or further information, please write to:

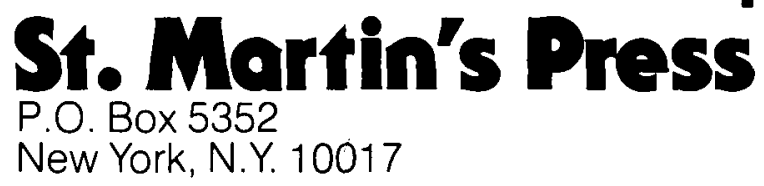




\section{Electoral Mobilization and Public Opinion \\ The Venezuelan Campaign of 1973

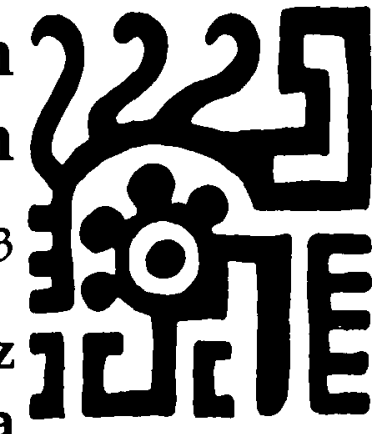 by John D. Martz
and Enrique Baloyra by John D. Martz
and Enrique Baloyra}

Analyzes systematically the mobilization of public opinion during Latin America's most intense political campaign of recent years. Data is drawn from personal observation, interviews with party elites, and a nationwide survey of Venezuelan public opinion. approx. 500 pp., $\$ 17.95$

The University of North Carolina Press

Box 2288 Chapel Hill, North Carolina 27514

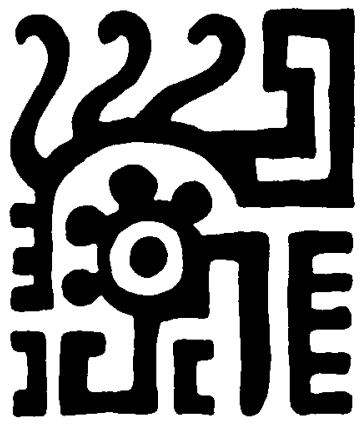




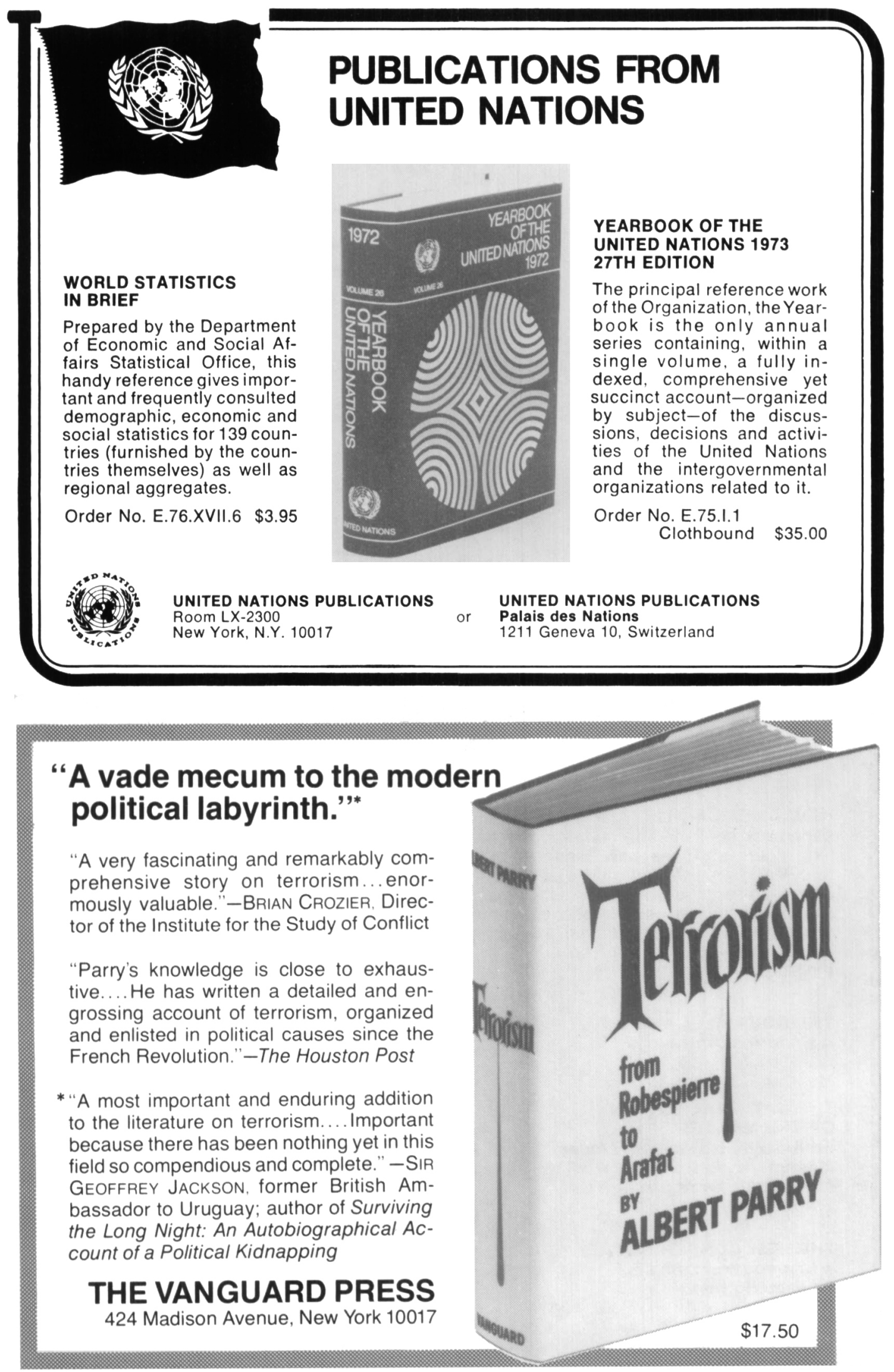




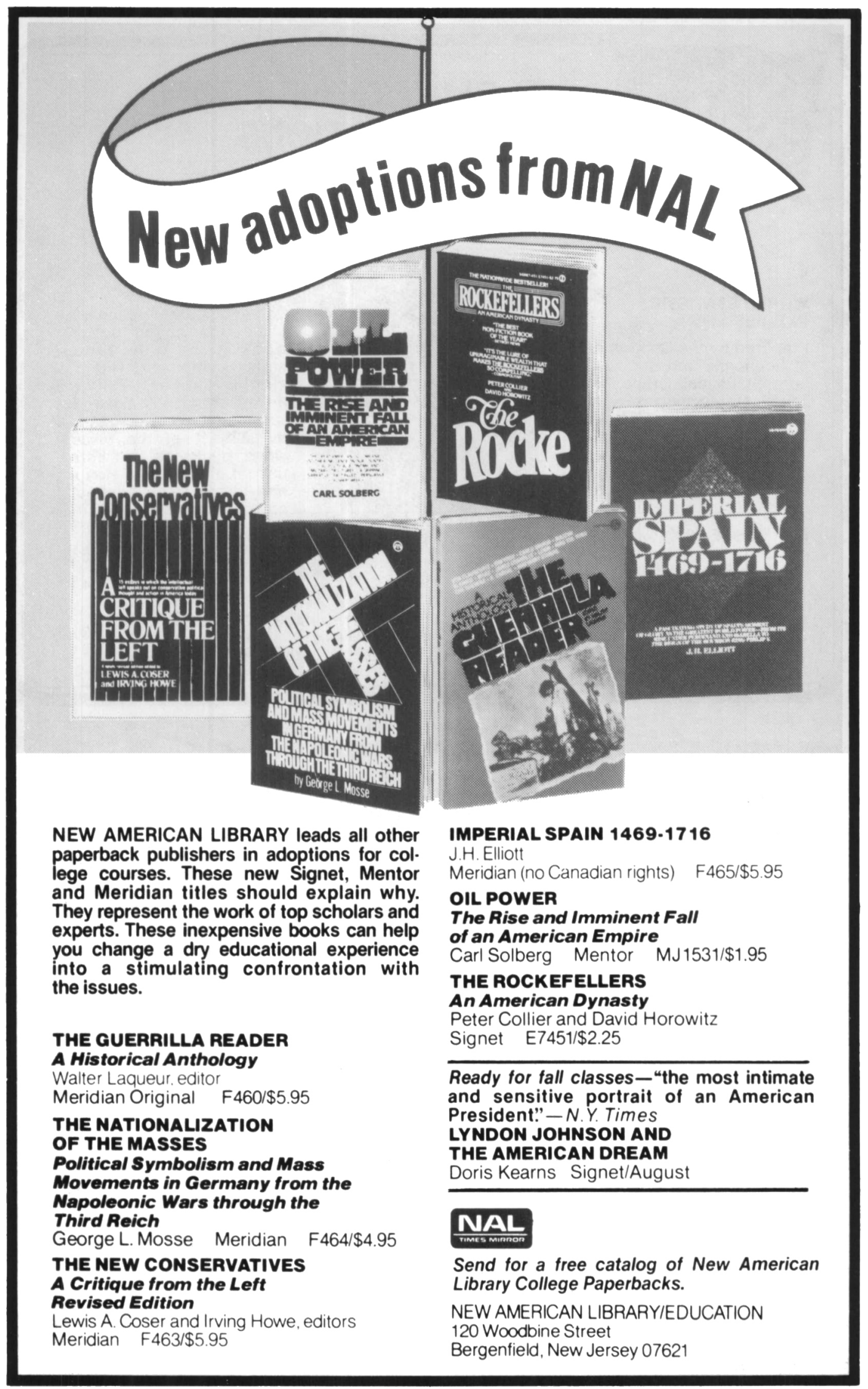

The American Political Science Review 


\section{NEW 1977 PUBLICATIONS:}

\section{POLITICAL PARTICIPATION:}

How and Why Do People Get Involved in Politics?, 2nd Edition

Lester W. Milbrath, SUNY, Buffalo and M.L. Goel, University of West Florida

A synthesis and review of what is known about

political participation, offering the most recent information.

C. 225 pages Paper 528-65095-5

\section{NEW PERSPECTIVES ON THE HOUSE OF REPRESENTATIVES, 3rd Edition}

Edited by Robert L. Peabody, Johns Hopkins University and Nelson W. Polsby, University of California, Berkeley

Including nine new contributions and updated, revised material, this collection gives students a sense of the changes that are occurring in the House.

c. 434 pages Paper 528-65101-3

\section{TH:AB: OUYSHANDTE AND \\ WIDHA-ADOPHHD THETS}

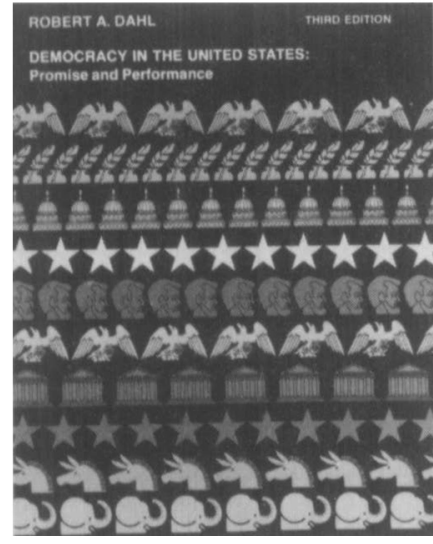

ROBERT A. DAHL'S

DEMOCRACY IN

THE UNITED STATES,

Promise and Performance,

\section{Third Edition}

.. a systematic and thorough analysis of our political institutions and processes. Professor Dahl, of Yale University, presents an exposition on the American political system and encourages readers to develop their own perspectives and evaluations. An Instructor's Manual is also available.

514 pages Paper/528-65010-6

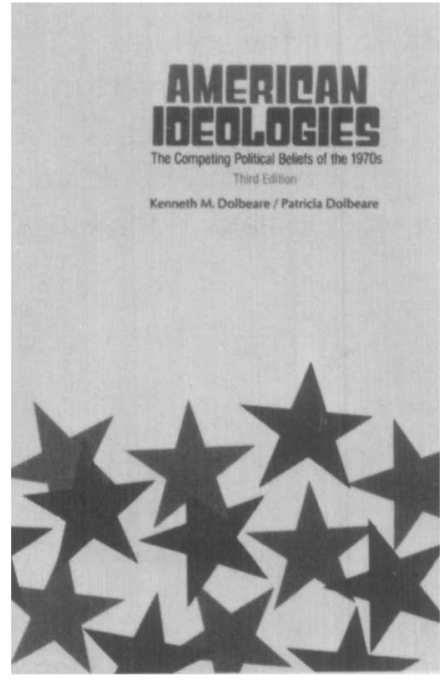

AMERICAN IDEOLOGIES: The Competing Political Beliefs of 'The 1970's, Third Edition

By Kenneth M. Dolbeare, University of Massachusetts, and Patricia Dolbeare a description, examination, and evaluation of eleven major ideologies, illustrating their similarities and differences. 232 pages Paper/528-65018-1

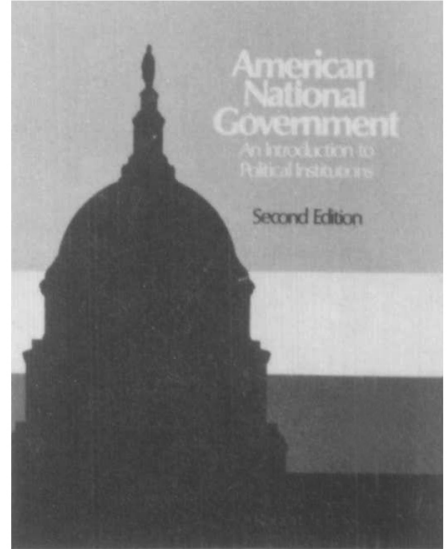

AMERICAN NATIONAL GOVERNMENT:

An Introduction to Political Institutions, Second Edition By Robert S. Ross, California State University at Chico . . a brief introduction to the major components of the federal government. The attention given to recent events helps the student to understand the relationship between government and those governed. An Instructor's Manual is available.

249 pages Paper / 528-65005-X

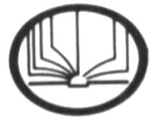




\section{Distinguished authors, timely analysis.}

\section{Irving Louis Horowitz IDEOLOGY AND UTOPIA IN THE UNITED STATES 1956-1976}

The American experience with national defeat is the subject of these 24 essays, by a scholar who is "an exceptionally prolific and significant practitioner of the sociologist's craft.... (His) essays are rich in insight and very often are models of penetrating analysis of the subject matter."

-Walter Dean Burnham, Professor of Political Science, M.IT. \$17.95 cloth, \$5.95 paper (A Galaxy Book GB 477)

\section{Richard Lowenthal MODEL OR ALLY?}

The Communist Powers and the Developing Countries To foster ideologically pure Marxist/Leninist models or to build pragmatic alliances-this is the dilemma of Soviet and Chinese policy that Richard Lowenthal analyzes "with lucid, original, informed and often brilliant insights." -Alexander Dallin, Stanford University. \$12.95

\section{OXFORD UNIVERSITY PRESS}




\section{- Does "the Catholic}

vote" really exist?

- Are Southern Baptists more politically conservative than Northeastern Unitarians?

- Was Jimmy Carter elected by Republican Protestants?

These and many other interesting questions are answered in RELIGION AT THE POLLS: the first book about the role of religion in the American electoral process-from the days of Jefferson right through the election of President Carter.

Special sections of the book show how Catholics, Jews, Baptists, Methodists, Lutherans, Presbyterians, Episcopalians, Mormons, and other groups tend to vote. Also included is fascinating and virtually unknown data on the denominational make-up of Congress and how it affects legislation, and an analysis of the political significance of such issues as parochial school aid and abortion.
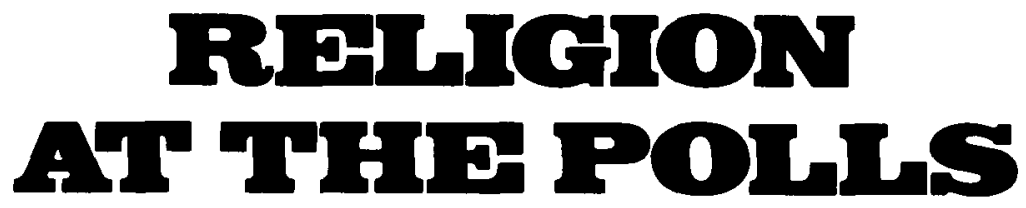

\section{by ALBERT J. MENENDEZ}

Paperbound $\$ 5.95$ Available at

your bookstore or direct from the publisher.

THE WESTMINSTER PRESS

905 Witherspoon Bldg., Philadelphia, Pa. 19107 


\section{STRATEGIC PERSPECTIVES IN SOCIAL POLICY Edited by John E. TROPMAN, Milan DLUHY, Roger LIND, Wayne VASEY and TOM A. CROXTON, University of Michigan}

The development of social policy by administrators requires an assessment of goals, elements of social change and of the politics of policy-making. The emphasis of this text is on the process of intervention in developing a policy for practical ends. Strategic points of intervention within the policy system are examined from the point of view of the policy makers, policy conceptualizers and students of government. Included are guides for both social policy and social program analyses of interest to students of public administration, policy science, social work, urban and regional planning, and political science.
$381 \mathrm{pp}$
1976
$008018226-7 \quad$ i
$\$ 8.50$
$008 \quad 018227-5 \quad h$
14.50

\section{POLICY SCIENCES: METHODOLOGIES AND CASES}

\section{By Arie Y. LEWIN, Duke University,} and Melvin F. SHAKUN, New York University

POLICY SCIENCES: METHODOLOGIES AND CASES presents a pragmatic, descriptive/normative methodology for policy analysis, within which different disciplines can be iritegrated for policy analysis and formulation. Part 1 presents the framework within which components of policy science may be integrated and applied to real decision problems. Part 2 focuses on methodologies: and $P$ art 3 presents a number of cases that apply the methodologies to real world problems. Designed as a text for a course in policy sciences and interorganizational decision-making. or for similar course at the advanced undergraduate or graduate level, this book is also suitable as a basic reference for practicing policy scientists and policy makers.
$500 \mathrm{pp}$
1976
$\begin{array}{llll}0 & 08 & 019600-4 & f \\ 0 & 08 & 019601-2 & h\end{array}$
$\$ 17.00$
23.00

\section{HUMAN BEHAVIOR AND PUBLIC POLICY: A POLITICAL PSYCHOLOGY \\ By Marshall H. SEGALL, Syracuse University}

Based upon the conviction that existing knowledge of human behavior contains important lessons for policy makers, this book aims to demonstrate that important social and politica! implications are inherent in social, psychological research findings. What social psychologists know, or know how to find out, is of crucial relevance to the real world. Knowledge as to why and under what conditions people behave as they do permits evaluation of social policy alternatives.

Written primarily for undergraduates, this book contains illustrations of the implications of existing social psychological findings for such problems as intergroup relations. educational innovations, relations between the sexes, and the control of violence in a free society.

This work contains most of what is included in a traditional social psychology course but embeds it in a context of relevance.
$336 \mathrm{pp}$
1976
$\begin{array}{lllll}0 & 08 & 017853-7 & \text { i }\end{array}$
$\$ 9.50$
$0 \quad 08 \quad 017087-0 \mathrm{~h}$
18.00

\section{PERGAMON PRESS}

Fairview Park. Elmsłord. New York 10523 \& Headıngton Hill Häl, Oxford OX3 OBW. England 
F. E. PEACOCK PUBLISHERS, INC.

\title{
INTRODUCTION TO INTERNATIONAL POLITICS
}

By Robert D. Cantor, Temple University
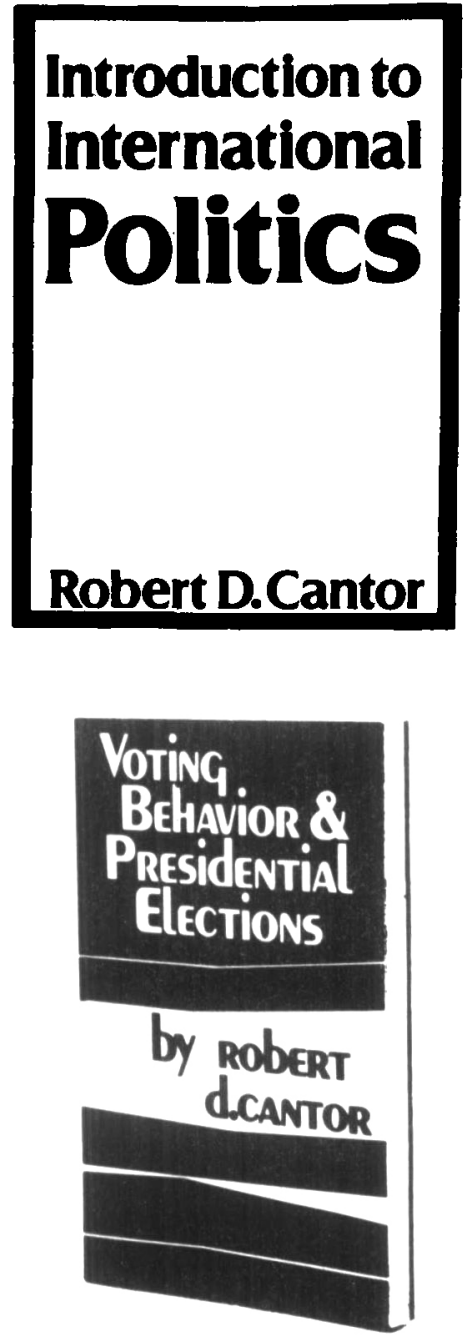

With very nearly 100 adoptions this new text in international politics has been used by those who wish a clear, interesting, current exposition.

A recent user has written:

"This is an excellent text for an introductory course at lower levels or in junior colleges. It avoids the abstraction and incomprehensiveness of many introductory texts and makes the dynamics of international politics fully understandable to beginning students. It is thoroughly up to date, beautifully illustrated and the increased emphasis on international economics is appropriate and laudable."

1976,323 pages, $\$ 10.50$ cloth

\section{VOTING BEHAVIOR AND PRESIDENTIAL ELECTIONS}

\author{
By Robert D. Cantor
}

Widely adopted, this recent text emphasizes the political climate existing at the time of the elections and its impact upon voting decisions. Campaign techniques and spending are also discussed. 1975,130 pages, $\$ 3.75$ paper

\section{THE NEW PUBLIC PERSONNEL ADMINISTRATION}

Felix A. Nigro, University of Georgia, and Lloyd G. Nigro, Syracuse University

This book provides an analysis of public personnel administration as it exists today. It discusses how programs have been affected by new developments, principally equal employment opportunity, collective bargaining, and the new court decisions with respect to constitutional rights of public employees.

It also provides a theoretical framework, based on open system theory, for understanding the relationship between personnel administration and organizations. 1976, 337 pages, $\$ 10.00$ cloth 


\section{F. E. PEACOCK PUBLISHERS, INC. takes pleasure in announcing Spring publication of}

NATIONAL GOVERNMENT AND POLICY IN THE UNITED STATES Edited by Randall B. Ripley and Grace A. Franklin, The Ohio State University

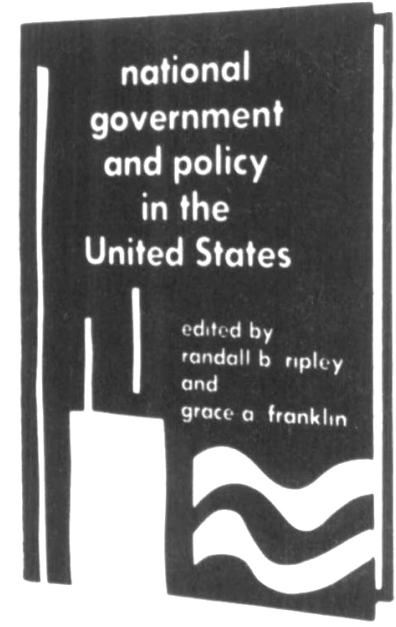

This introductory reader emphasizes the important aspects pertaining to how public policy gets made in the United States. The readings offer insight into governmental institutions, the national policy process, and the substance of some policy areas. In the general introductory essay and the shorter introductory notes to each of eleven sections of readings the editors underscore the specific relevance of individual readings to broader questions about the institutions, processes, and policies of American national government. March, 1977, c. 350 pages, c. $\$ 6.95$ paper

\section{NATURE AND CIVILIZATION: Some Implications for Politics By Mulford Q. Sibley, University of Minnesota}

This is an essay in political theory

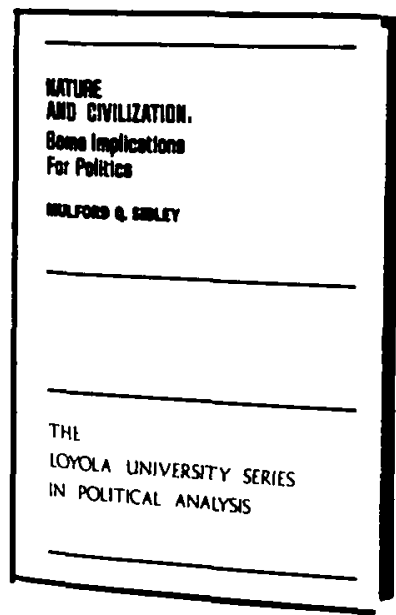
turning on the categories of Nature, Human Nature and Civilization. The book endeavors to explore conflicting theories of the three concepts and to relate them to problems of politics.

The book is neither a volume in the history of political thought nor one which treats only of what some might call "analytical" political theory. Instead, it seeks to show relations of political theory to such areas of human concern as technology and political economy.

March, 1977 , c. 320 pages, c. $\$ 9.50$ cloth

F. E. Peacock Publlshers, Inc. Itasca, II., 60143 


\section{8 new books with great political influence... from John Wiley \& Sons}

\section{STATECRAFT}

An Introduction to Political Choice and Judgment Charles W. Anderson,

University of Wisconsin-Madison

This decision-making approach to political analysis and problem solving emphasizes the viewpoint of the participant rather than that of the observer. Anderson takes into account the role of the policy maker, then the role of the advocate-to show how one should go about making a decision concerning a controversial problem and defending that decision with reasoned arguments. An ideal text for Intro. to Politics and other courses on policy.
(0 471 02896-7)
1977
$318 \mathrm{pp}$.
$\$ 11.95$

\section{CONTEMPORARY ISSUES IN POLITICAL THEORY}

Robert Booth Fowler,

University of Wisconsin-Madison,

\& Jeffrey R. Orenstein, Kent State University

This contemporary approach to theory covers the major topics that fit the scheme of political valuesanarchy, democracy, justice, liberty and equality, obligation, and revolt-discussing their historical roots to evaluate their present-day significance. $\begin{array}{lll}(047127031-8) & \mathbf{1 9 7 7} & 168 \mathrm{pp} . \quad \$ 10.95 \text { cloth }\end{array}$ (0 $47127032-6) \quad \$ 5.95$ paper

\section{ADMINISTRATION IN THE PUBLIC SECTOR}

Harold F. Gortner, Indiana University

Public administrators must understand the functions of management in guiding the public organization-and at the same time know how to operate within the political system. Gortner gives proper cognizance to this increasingly important role of state and local public administrators in the overall administrative operation.
(0 471 31891-4)
1977
368 pp.
$\$ 11.95$

\section{POLITICS IN INDUSTRIAL}

\section{SOCIETIES}

A Comparative Perspective

Lawrence C. Mayer with John H. Burnett,

both of Texas Tech University

This book presents a comparative analysis of various Western European industrialized societies by describing and explaining their political structures. The authors suggest cultural, sociological, and historical variables as determinants of patterns in these societies, and explore the effects of technology on constitutional differences.

$(047157986-6) \quad 1977 \quad$ approx. 532 pp. $\$ 12.95$ (tent.)

JOHN WILEY \& SONS, Inc.

605 Third Avenue

New York, N.Y. 10016

In Canada: 22 Worcester Road, Rexdale, Ontario Prices subject to change without notice.

A 2240-02

\section{AMERICAN LEGAL PROCESSES \\ William P. McLauchlan, Purdue University}

What really goes on in the American courtroom? What is the court's role in society? What is the difference between trial and appellate courts? These are only a few of the questions that McLauchlan answers in this complete description of the American legal system. He treats the courtroom as one great dispute-settling arena and examines the roles of the plaintiff and defendant in civil litigation. A volume in the Wiley Series on Viewpoints on American Politics-Samuel Krislov, Series Editor
(0 $47158560-2)$
(0 471 58561-0)
$1977218 \mathrm{pp}$.
$\$ 10.95$ cloth

\section{OFFENSE AND DEFENSE IN THE INTERNATIONAL SYSTEM} George H. Quester, Cornell University

Tracing the overall impact of military technology through chronological history, this book presents a systematic study of how military force determines the shape of politics. Quester uses a macrocosmic approach to examine the tendency toward offense or defense, and cites particular military campaigns and technological innovations that have affected warfare throughout the centuries. A volume in the Wiley Series on International Relations-Richard Rosecrance, Series Editor

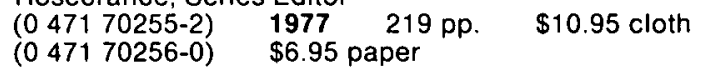

\section{INTERNATIONAL RELATIONS}

A Policymaker Focus Robert L. Wendzel, University of Maine

Using a policymaking approach, this book provides a concise core analysis of the fundamentals of international relations. Wendzel offers an actual feel for the feasible options which should be pursued in specific situations, giving a pragmatic analytical framework for viewing current and future problems that policymakers face.

$\begin{array}{llll}(047193361-9) & 1977 & 286 \text { pp. } & \$ 7.95\end{array}$

\section{PEOPLE AND POLITICS \\ An Introduction to Political Science Herbert R. Winter, Rhode Island College \\ \& Thomas J. Bellows, University of Arkansas- in collaboration with Conrad Waligorski, University of Arkansas \& Stanley Erikson, Professor Emeritus, Augustana College}

This comparative examination of political phenomena combines the traditional aspects of the discipline with an understanding of modern empirical approaches. This systems approach permits the use of political features common to all societies and serves as a starting point for analysis and discussion. (0 471 95485-3) $\quad 1977 \quad 528$ pp. $\$ 12.95$

To be considered for complimentary examination copies, write to Irving Cooper, Dept. A 2240. Please include course name, enrollment, and title of present text. 


\section{INSIDE THE SYSTEM}

Third Edition

Edited by CHARLES PETERS and JAMES FALLOWS of The Washington Monthly

Sound but irreverent analyses of the inner workings of American government and the antics of our politicians drawn from the Washington Monthly.

$1976 \quad 352 \mathrm{pp}$. $\$ 4.95$

\section{THE PRESIDENCY REAPPRAISED}

Second Edition

Edited by THOMAS E. CRONIN, Brandeis University and REXFORD G.

TUGWELL, Center for the Study of Democratic Institutions

Seventeen re-examinations of the problems and potentials of the post-

Watergate Presidency by well-known scholars and journalists.

April, $1977320 \mathrm{pp} . \quad \$ 4.95$

\section{CONGRESS RECONSIDERED}

Edited by LAWRENCE C. DODD. University of Texas-Austin and BRUCE I. OPPENHEIMER, Brandeis University

Provocative reassessments by leading scholars of Congress' actual and potential role in policy-making and its capacity to be a truly representative institution.

April, $1977 \quad 320 \mathrm{pp} . \quad \$ 4.95$

\section{GROUP POWER}

Lobbying and Public Policy

CAROL S. GREENWALD, Brooklyn College of the City University

of New York.

An up-to-date introduction to the role of groups in the American public policy process. Uses cose studies throughout to examine groups in action and the diverse sources of their power.

April, $1977 \quad 288 \mathrm{pp} . \quad \$ 4.95$

\section{THE POLITICS OF ENVIRONMENTAL CONCERN}

Second Edition

WALTER A. ROSENBAUM, University of Florida

This new edition examines the maturation of EPA and adds two new and urgent issue areas, energy needs and land use, to its coverage of major environmental policy and problems.

April, $1977 \quad 320$ pp. $\$ 4.95$

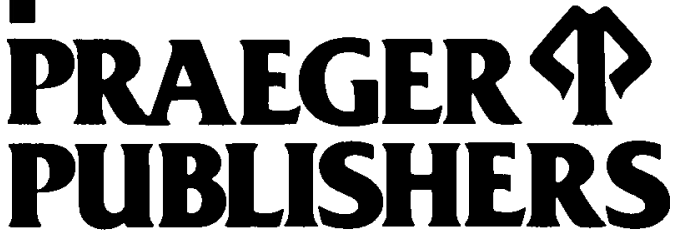

20O PARK AVENUE, NEW YORK, N.Y. 10017 


\section{AMERICAN FOREIGN POLICY SINCE WORLD WAR II}

Seventh Edition

JOHN SPANIER, University of Florida

A comprehensive study updated to include the fall of the Saigon regime, the impact of the energy crisis on international economics, and the latest

Great Power relationships. February. $1977 \quad 368 \mathrm{pp} . \quad \$ 4.95$

PUBLIC POLICY-MAKING

JAMES E. ANDERSON, University of Houston

A complete framework for understanding the American policy-making process from the emergence of issues through implementation and evaluation of laws.

$1975 \quad 192$ pp. $\quad \$ 3.95$

\section{CASES IN PUBLIC POLICY-MAKING}

Edited by JAMES E. ANDERSON. University of Houston Readings focused on contemporary policy problems organized in the sequence of the policy process. Companion to Anderson's PUBLIC POLICY-MAKING. $1976 \quad 356 \mathrm{pp} . \quad \$ 5.95$

\section{URBAN POLITICS AND PUBLIC POLICY}

The City in Crisis Second Edition

Edited by STEPHEN M. DAVID, Fordham University and PAUL E. PETERSON, University of Chicago

A new selection of readings on urban problems focusing on policy dilemmas in housing, education, transportation, and police services.

$1976 \quad 352$ pp. $\quad \$ 5.95$

\section{INTRODUCTION TO AFRICAN POLITICS}

A Continental Approach

Second Edition

LESLIE RUBIN and BRIAN WEINSTEIN, Howard University

An up-to-date edition of what David Abernethy called "clearly the best written, most comprehensive, and most genuinely comparative study of

African politics currently available:

February, 1977 336pp. $\$ 5.95$

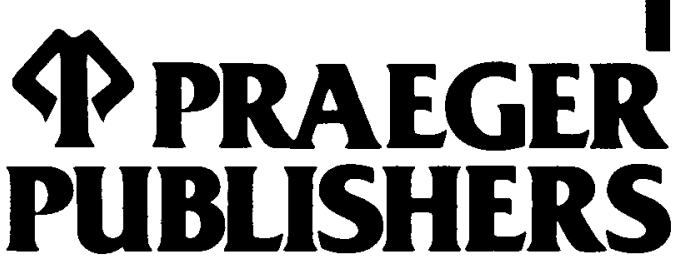

A DIVISION OF HOLT, RINEHART AND WINSTON 


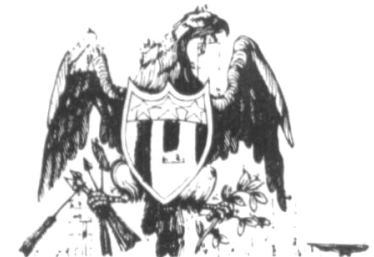

IMPORTANT BOOKS from PALISADES PUBLISHERS

\section{PRAGMATIC FEDERALISM: AN INTERGOVERNMENTAL VIEW OF AMERICAN GOVERNMENT} Parris N. Glendening and Mavis Mann Reeves

Breaks through the traditional one-level portrayal of American government and presents new dimensions of realism through interlevel and intralevel perspectives-national-state, interstate, national-local, state-local, and interlocal relations. Suitable for courses in introductory American government, introductory political science, state and local government and politics, public administration, intergovernmental relations, and federalism. "One of the first serious efforts to examine intergovernmental relations as a dynamic process." John Sanzone, California State University, Chico. "Virtually certain to be widely used because of its fresh approach and its adaptability to many courses." - prepublication reviewer.

1977, 334 pp., \$7,50 paper. Instructor's manual.

\section{GOVERNMENT AT THE GRASS-ROOTS, Second Edition}

\section{George S. Blair}

The only book that gives thorough consideration to all types of local governments. Even more importantly, it focuses on the foundations of such governments-their institutions, organization, processes, operations, and intergovernmental relations. Suitable for city, local, urban, metropolitan, and state and local government and politics courses. "Fills the need for material on local government that is not exclusively urban in focus and is separate from lengthy discussions of state government." - Richard Rich, Virginia Polytechnic Institute and State University.

1977,342 pp., $\$ 7.50$ paper.

\section{THE EFFECTIVE PRESIDENT}

Edited by John C. Hoy and Melvin H. Bernstein

A tough-minded book composed entirely of original contributions by seasoned observers who offer diverse appraisals of the American presidency. Made up of formal presentations, commentaries, and questions and answers. Contributors include Hubert Humphrey, John Anderson, Ceorge Reedy, Douglas Cater, Mervin Field, Ceorge Gallup Jr., and Robert Novak. "An interesting cross-section of various issues and attitudes on the American presidency presented in a dynamic give-and-take situation." - William Wagner, Foothill College.

1976, 192 pp., $\$ 4.95$ paper.

\section{WHY WATERGATE?}

Edited by Paul J. Halpern

A widely acclaimed and adopted collection of essays by seventeen social scientists and writers who interpret what has been happening to the American presidency in recent years. The book's significance extends far beyond the immediate events of Watergate. Sections are integrated by perceptive head notes and by the editor's introductory chapter.

233 pp., $\$ 4.75$ paper.

\section{YORTY: POLITICS OF A CONSTANT CANDIDATE}

\section{John C. Bollens and Grant B. Geyer}

A penetrating, highly candid analysis of the campaign tactics and themes of a tireless politician. Students in many colleges and universities have been fascinated by planning counteractions to the techniques of this man who has numerous counterparts elsewhere.

245 pp., student edition, \$4.25.

For adoption consideration, request examination copies from Derek Johnson, Marketing Manager. Give course number and title and when text adoption decisions will be made.

All these books are also published in hardbound editions; inquiries from libraries are welcomed.

\section{PALISADES PUBLISHERS}

\author{
P.O. Box 744, Dept. S
}

Pacific Palisades, CA 90272 


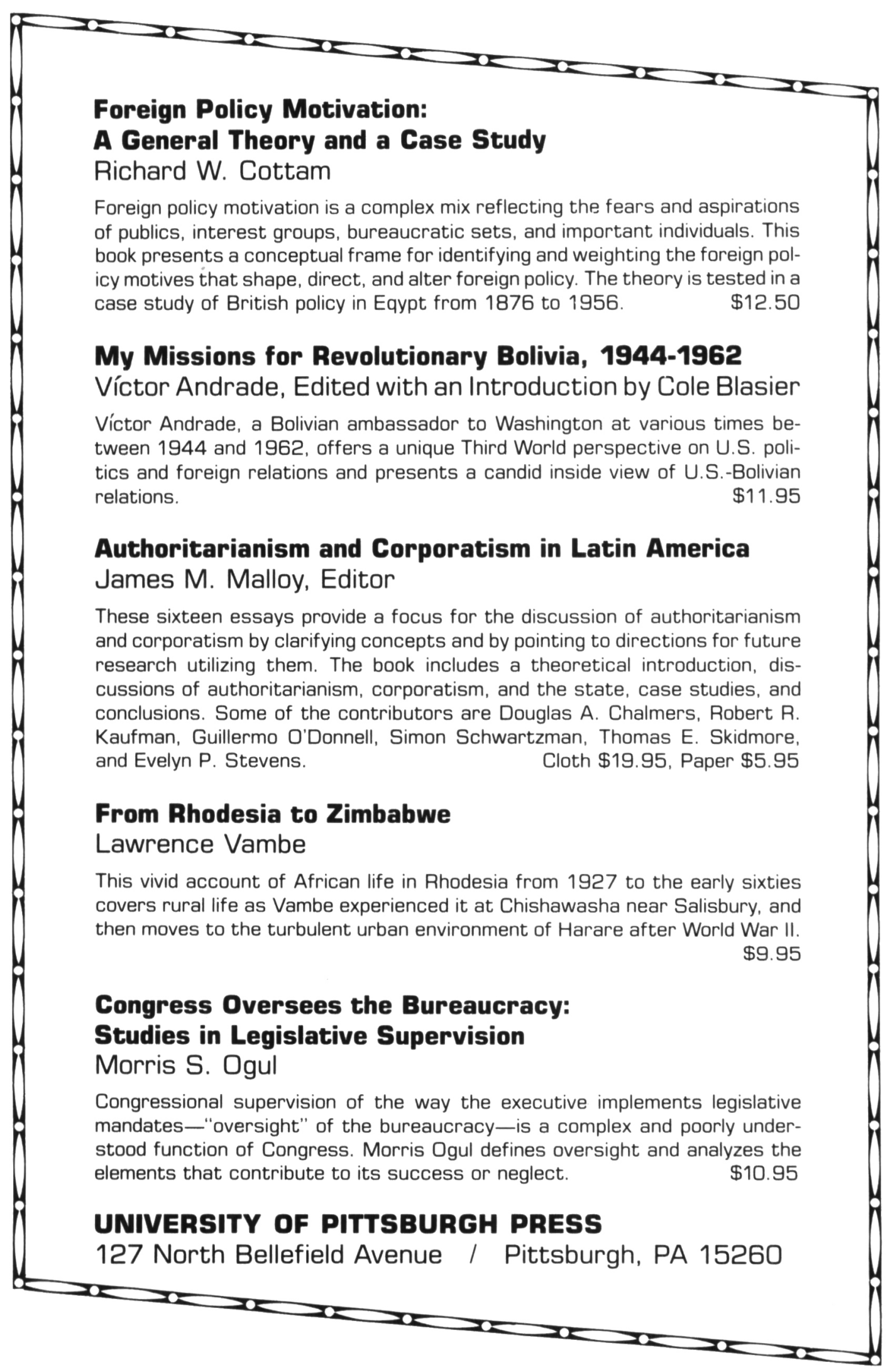




\section{Choices- for introductory courses Orsurveys of American Government Branches}

Available this spring!

\section{THE LEGISLATIVE PROCESS}

Third edition

Malcom E. Jewell, University of Kentucky; and Samuel C. Patterson, University of lowa

This thorough up-to-date Third Edition provides a thoroughly integrated examination and analysis of the American legislative process. Its purpose is to enable students to understand their own state legislatures in relation to Congress.

Random House / March 1977 / 592 pages / paperbound / Order Code: 37265

\section{AMERICAN GOVERNMENT: Democracy and Liberty in Balance}

Ruth C. Silva and Edward Keynes, both of Pennsylvania State University; Hugh A. Bone, University of Washington; and David W. Adamany, University of Wisconsin

This basic text on American politics examines Congress, the Presidency, and the Judiciary with a focus on the conflict between individual freedom and majority rule. Each institution is given a separate section while all are linked with ample illustration of the policy-making process. Instructor's Manual.

Alfred A. Knopf/1976/544 pages/hardbound/Order Codes: 31644 , 37776 (I.M.)

\section{PUBLIC ADMINISTRATION:}

\section{Politics and the Political System}

William L. Morrow, College of William and Mary

In theory the public administrative bureau is not a political animal; in practice it is. This book presents an analysis of how external forces shape the role of public agencies in our society. The overriding queston is: How can the bureaucracy be made more responsive to public needs?

Random House/1975/320 pages/paperbound/Order Code: 37780 


\title{
THE POWER OF THE MODERN PRESIDENCY
}

\author{
Erwin C. Hargrove, Brown University
}

How extensive has presidential power become during the last 25 years? Has executive authority surpassed regulation? Professor Hargrove deals with these and many other timely questions in this in-depth analysis of the contemporary presidency, presenting a new model of presidential leadership.

Alfred A. Knopf / October 1974/ 356 pages/paperbound/Order Code: 37724

\section{AMERICAN GOVERNMENT TODAY}

Excellent for an introductory course in American Government! Using this text, students learn to analyze government and its actions rather than simply reviewing the facts. Organized so that the material can be used in any sequence, American Covernment Today examines how priorities are established and how public policy decisions are made and executed with the political process. Instructor's Manual and Student Study Guide available.

CRM/Random House/1974/515 pages/hardbound/Order Codes: 30025, 30032 (I.M.), 31731 (SS.G.)

\section{AMERICA'S POLITICAL SYSTEM}

\section{Second Edition}

Peter Woll and Robert Binstock, both of Brandeis University

Utilizing a systems framework, the text is designed to explain in a realistic manner facts of the governmental process. The book contributes to an understanding of politics by viewing American government as part of a system in which inputs flow from a variety of sources to the decision-making structures.

Random House / 1975 / 576 pages / paperbound / Order Codes: 31826,31939 (I.M.)

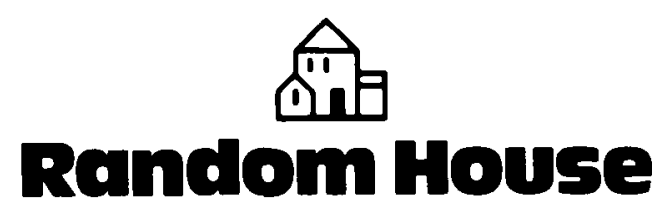

College Review Desk 53, 400 Hahn Road, Westminster, Maryland 21157 


\section{Keep up with the Country...}

\section{with the new Third Edition of DEMOCRACY UNDER PRESSURE}

\section{Recently,} the nation has:

$\square$ witnessed a phenomenal election year

- elected a new President

$\checkmark$ amended the Federal Election Campaign Act of '74

$\square$ uncovered major abuses of power by federal intelligence agencies

$\square$ proposed legislative reforms through the new Senate oversight committee

$\checkmark$ felt the impact of the Burger Court on civil rights and civil liberties

$\square$ paid increasing attention to the influence of multinational corporations at home and abroad

$\checkmark$ debated the issues of energy needs versus ecological stability

$\square$ perceived the limitations of governmental solutions to national problems

$\square$ understood the restraints on American power throughout the world

And all these crucial events, developments, and issues are carefully analyzed and explained for your students in this new Third Edition of Democracy Under Pressure. This

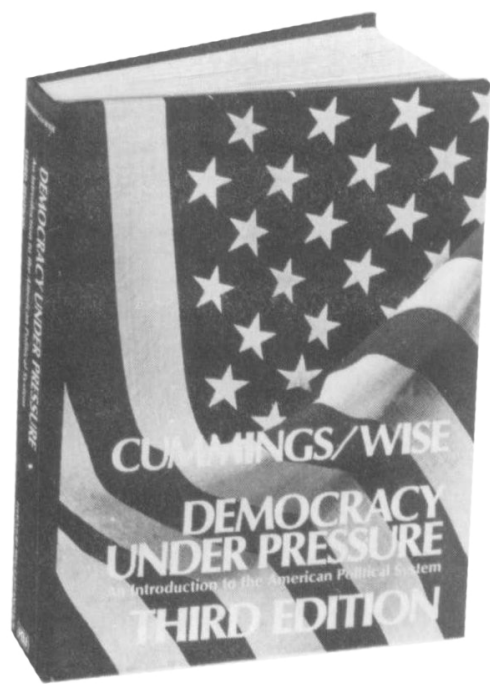

leading introduction to American government provides a critical yet balanced examination of our political system - its achievements as well as its shortcomings - written in a style that is at once readable, authoritative, and thought-provoking. More than 50 boxed inserts (brief quotations from contemporary political science literature, news and committee reports, and political figures) provide pointed commentary on the text discussion, and a lavish illustration program of some 375 photographs, cartoons, graphs, and tables depicts the themes and events discussed throughout.

\section{DEMOCRACY UNDER PRESSURE AN INTRODUCTION TO THE AMERICAN POLITICAL SYSTEM Third Edition \\ MILTON C. CUMMINGS, JR., The Johns} Hopkins University and DAVID WISE, political analyst and author of The Politics of Lying: Government Deception, Secrecy, and Power. The American Police State, and co-author of The Invisible Government. 650 pages (probable)

coming in April

Accompanied by an Instructor's Manual with Tests and Learning Objectives 


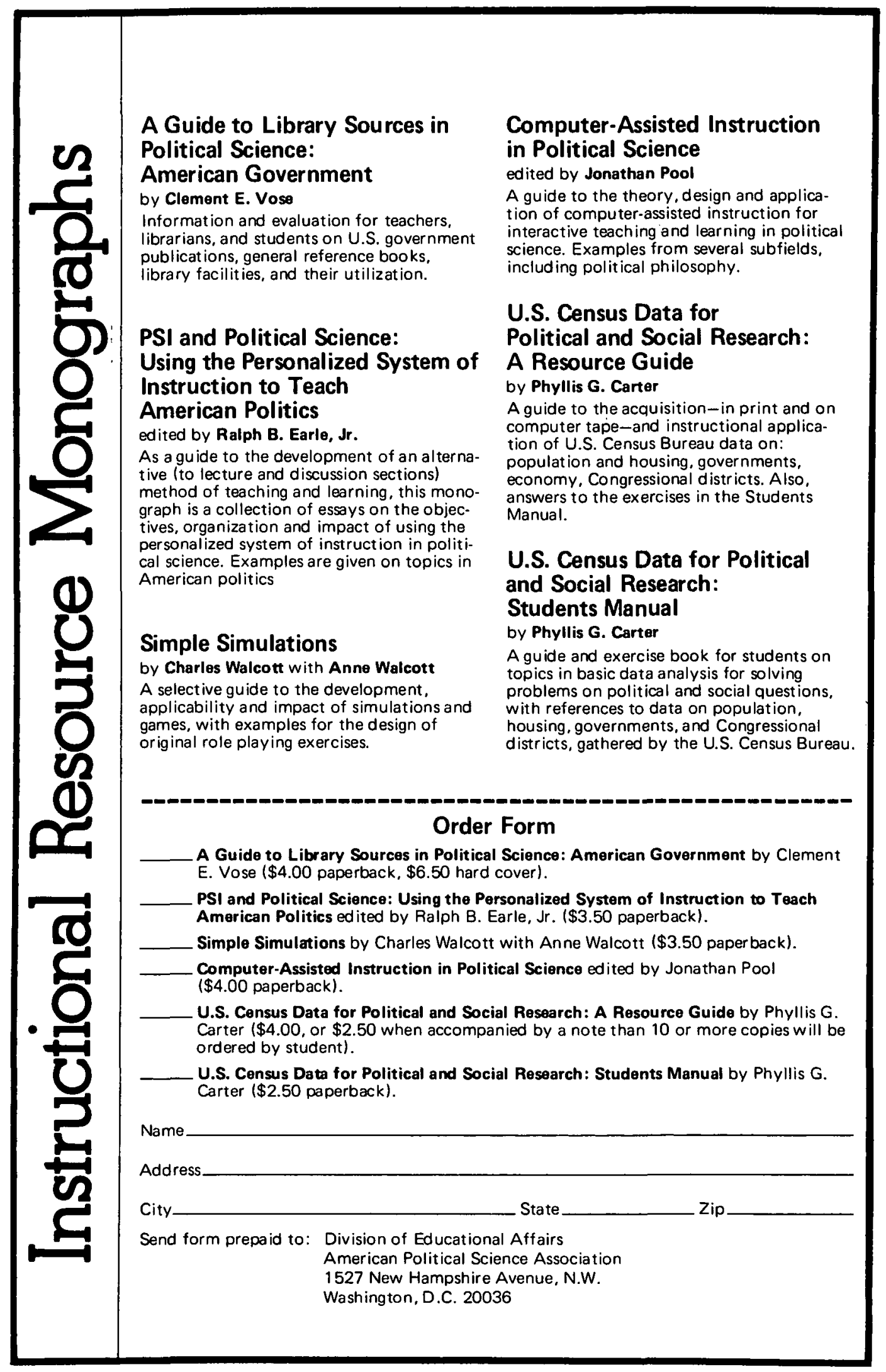




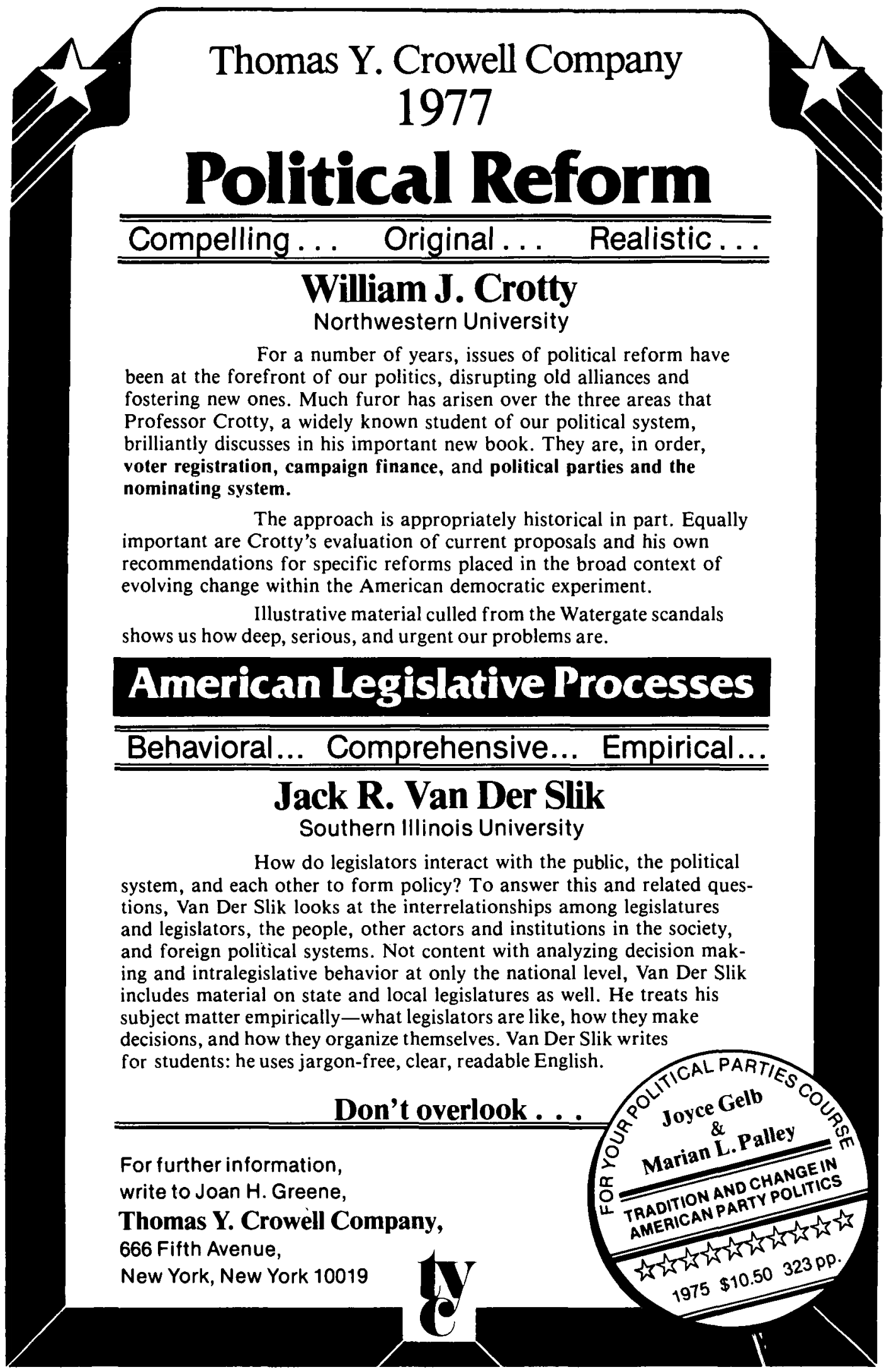




\section{The Election of 1976}

\section{Reports and Interpretations}

By Gerald M. Pomper, Rutgers, the State University of New Jersey. In this early interpretation of the crucial election of 1976, five specialists in American politics analyze the Presidential nominations, the Presidential election, the issues of the campaign, the Congressional election and legislative prospects, the likely course of the new administration, and the significance of the election to the course of American history. The contributors include: Ross K. Baker, Wilson Carey McWilliams, Jr., Henry A. Plotkin, and Charles E. Jacob. This volume will supplement every American politics text and bring it up to date.

Paper, $\$ 3.95$; cloth, $\$ 8.95$

\section{A Portrait of Marginality}

The Political Behavior of the American Woman

Edited by Marianne Githens, Goucher College and Jewel L. Prestage, Southern University. Women in politics become intensely involved with two roles: that of women and that of politicians, each of which places contradictory demands on them. The writers trace the social and political factors which create this marginal position, complications faced by black female politicians, and discuss the characteristics and performance of women in politics and the effect that this condition of marginality has had on public policy.

Paper, \$6.95

\section{Political Change in Japan}

\section{Response to Postindustrial Challenge}

By Taketsugu Tsurutani, Washington State University, Pullman. This is the first evaluation of Japanese politics in its own ecological terms. Avoiding the conventional structuralist and functionalist approaches, Tsurutani examines salient dimensions of recent political change in Japan from the perspective of evolutionary transition from industrial to postindustrial society.

Paper, \$6.95; cloth, $\$ 12.50$

\section{The French Polity}

By William Safran, University of Colorado. A comprehensive treatment of the French political system combining modern and traditional approaches. It is organized around a number of themes, among them: institutional innovation within the context of constitutional continuity; the importance of old and new decision-making structures; the persistence of administrative centralism; democratic forms of elite selection; the distinction between ideological commitments and political behavior patterns; and the continuation of multiparty politics.

Paper, \$6.95; cloth, $\$ 12.50$

\section{Class, State, and Crime}

\section{On the Theory and Practice of Criminal Justice}

By Richard Quinney. Quinney discusses the criminal justice policies of recent years. Class struggle, he says, is increasingly becoming a political issue, and the future of criminal justice seems to depend on the increasing political consciousness of the working class. It is contributing to political action for a transition from capitalism to socialism and may herald the introduction of a form of popular justice.

Paper, $\$ 4.95$; cloth, $\$ 8.95$

DAVID McKAY COMPANY, INC. 750 Third Avenue, New York 10017 


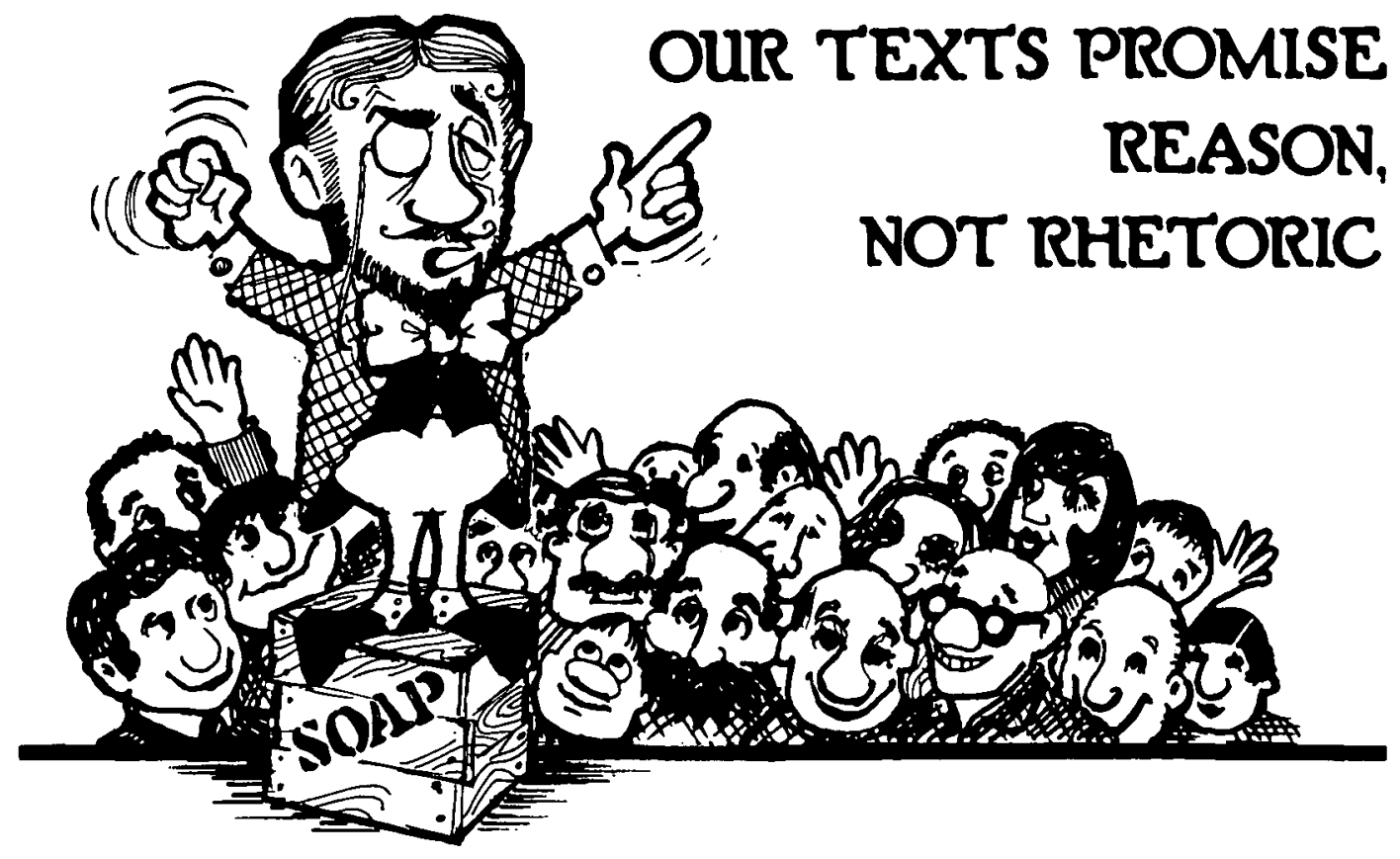

AMERICAN

FEDERAL GOVERNMENT, Thirteenth Edition

1977,512 pages, $\$ 12.95 *$

\begin{abstract}
AMERICAN SYSTEM OF GOVERNMENT, Thirteenth Edition 1977,640 pages, $\$ 14.95 *$
\end{abstract}

\section{John H. Ferguson and Dean E. McHenry}

The most thorough revision in the thirtyyear history of these highly successful texts. More than $50 \%$ rewritten, both books have been reduced in length, and the writing has been made simpler, clearer, and more readable for today's student.

Features you'll find in both texts

- Results of the 1976 presidential election are analyzed

- Traditional political concepts and practices are re-examined in light of current issues

- Thoughtful coverage is given to revenue sharing, election financing,
Congressional reform and counterreform, the energy crisis and the Federal response to it, and other contemporary issues

Features you'll find in AMERICAN SYSTEM OF GOVERNMENT

- Increased emphasis on citizen participation at the local level

- New discussion of finances and services including state and local debt

- Five chapters that explore in depth state and local government and the problems and challenges they face 
UNDERSTANDING AMERICAN POLITICS THROUGH FICTION,

Second Edition

Myles L. Clowers,

San Diego City College,

and Lorin Letendre,

CTB/McGraw-Hill and Cabrillo College

Organized to accommodate either the topical (institutions) or the systems approach, this paperback features writers from the entire political spectrum. New to this edition: A new chapter on the Constitution; a new chapter on policy; and new selections on political polling, political campaigning, interest groups, nativism and ethnic politics, bureaucratic discretion of the CIA, and plea bargaining. 1977, 356 pages, paper, $\$ 4.95 *$

\section{POLICE ADMINISTRATION,}

\section{Fourth Edition}

The late Orlando W. Wilson and Roy Clinton McLaren, Chief of Police, Arlington, Virginia and former Director, Field Operations Division, International Association of Chiefs of Police

This text covers all aspects of police administration, establishing a coherent system which is internally consistent. New to this edition: A new chapter on team policing; a new chapter on management theory and organizational behavior; and new material on the impact of women and minorities in law enforcement, the implications of several important pieces of recent legislation, management by objectives, zero-base budgeting, enhancement of productivity, crime resistance, SWAT, hostage negotiation, and technological advances. 1977,768 pages, $\$ 13.95$

*Instructor's manuals are available for these texts. Prices subject to change.
THE AMERICAN CONSTITUTION,

Third Edition

C. Herman Pritchett, University of California, Santa Barbara

Now in its third edition -- the classic analytical examination of the Constitution. More than 1,000 Supreme Court cases are analyzed or cited. New to this edition: Coverage of every important constitutional issue that has arisen, since the last edition -- including capital punishment, affirmative action, exclusionary zoning, abortion, and executive privilege, 1977,704 pages, $\$ 16.50$

\section{GOVERNING URBAN AMERICA, Fifth Edition \\ Charles R. Adrian, University of California, Riverside, and Charles Press, Michigan State University}

Written with sympathy for the problems of local government officials, this text presents a realistic appraisal of strengths and weaknesses of both government and citizens. New to this edition: New approaches to urban financing, especially revenue sharing; analysis of the trend toward structural change; reorganized and rewritten chapters on urban public and metropolitan areas; coverage of recent developments such as "neighborhood" government and minority and women candidates. 1977,512 pages, $\$ 12.95$

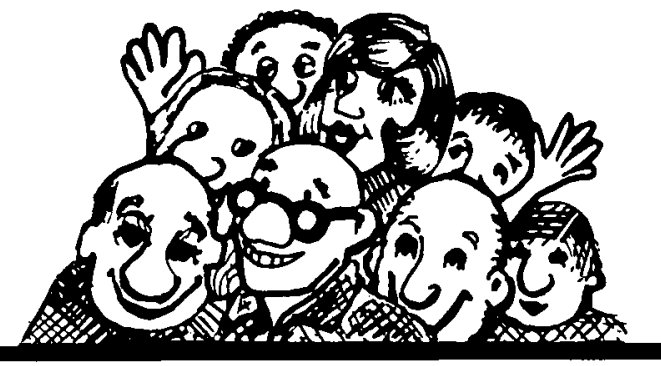




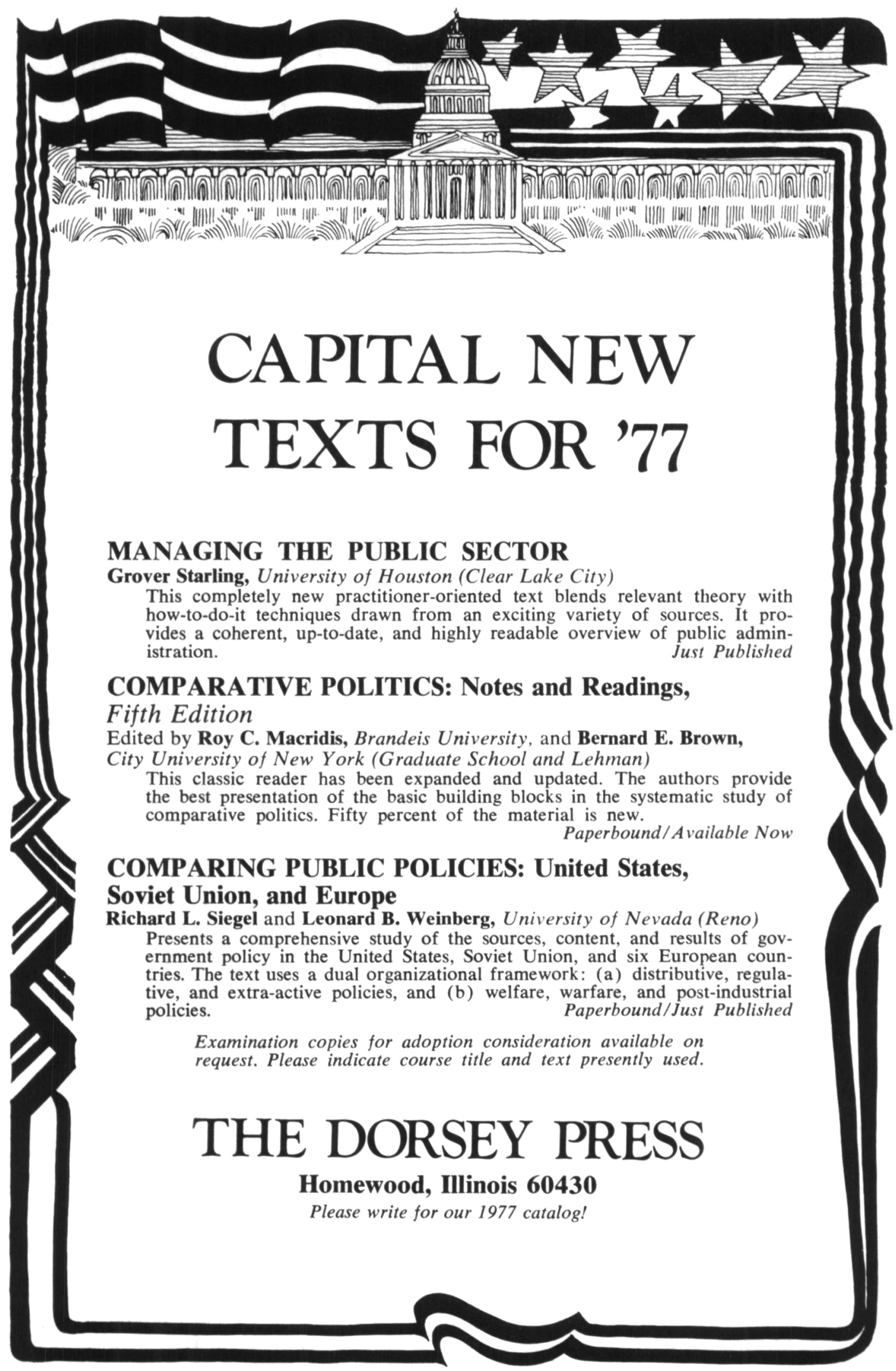




\section{Affairs of State}

Public Life in Late Nineteenth Century America

\section{Morton Keller}

"It is first rate-full of new ideas and new information and written with spirit." Henry Steele Commager

"An extraordinary piece of work and major contribution to our understanding of the American past." - Stephan Thernstrom

"A masterly and insightful analysis of the public life of Americans in the post-Civil War era." - David Rothman

"In this meticulously researched and annotated but highly readable book, ... Keller brings a sense of order to a chaotic era when American public institutions were beginning to face up to their social responsibilities..." Publishers Weekly

\section{Belknap $\$ 17.50$}

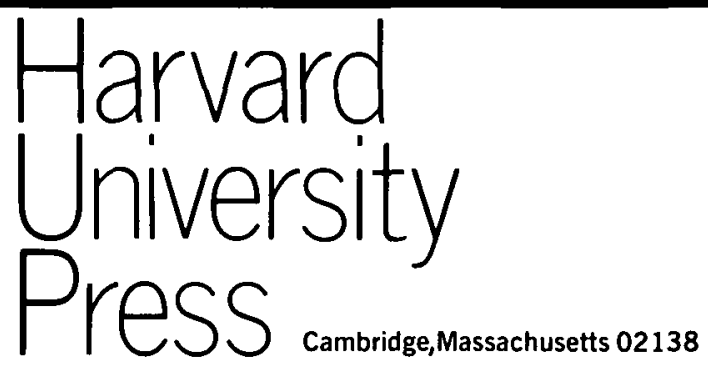




\section{"One of the most highly regarded, objective and responsible publications dealing with matters of public affairs."}

-Sen. Edward M. Kennedy

\section{REPRINT SERIES FOR CLASSROOM USE}

Used at more than 250 schools the first year it was available, the National Journal reprint series provides a low-cost, timely and invaluable collection of classroom reading material. The leading political scientists listed below have selected the reprinted articles and have written introductory essays. Each reprint contains four to eight articles. Please indicate which reprints you would like to review:

The Carter Presidency, Thomas E. $\square$ Politics and Parties, Nelson W. Polsby, Cronin, advisory editor, $\$ 2.35$, NEW EDITION

Congress, Richard F. Fenno Jr., advisory editor, \$2.35, NEW EDITION

Interest Groups, Robert H. Salisbury, advisory editor, \$2.35, NEW EDITION

Procurement Reform, Randall B. Ripley, advisory editor, $\$ 2.35$ advisory editor, \$2.35, NEW EDITION

Bureaucracy, Francis E. Rourke, advisory editor, \$2.35, NEW EDITION

Federalism, Daniel J. Elazar, advisory editor, $\$ 2.35$

Budget, Aaron B. Wildavsky, advisory editor, \$2.35, NEW EDITION

Unelected Representatives: Congress and the Information Explosion, Michael J. Malbin, advisory editor, \$2.35, NEW TITLE

\section{NATIONAL JOURNAL FACULTY SUBSCRIPTION RATES}

If your school library subscribes at our $\$ 200$ library rate, you are eligible to subscribe to National Journal at only $\$ 52$ per year. All orders must be pre-paid.
1 Year (52 issues) $\$ 52$
2 Years (104 issues) $\$ 104$

Please fill out and mail to:

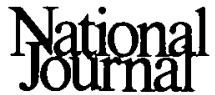

1730 M Street, N.W. Washington, D.C. 20036

\begin{tabular}{l} 
Name \\
Institution \\
Address \\
City 2 State \\
\hline
\end{tabular}




\section{Have you checked..}

THA A's new life insuránce rates?

The traditional "best buy" in life insurance is now even better, and you'l be startled to find how little it costs to own all the family protection you need. To illustrate,

at any issue age below 35 for men and 40 for women, a $\$ 50,000$ TIA A policy now costs less than $\$ 100 ;$ and $\$ 100,000$ policies are under $\$ 180$.

These are yearly net costs after current dividends (dividends not guaranteed) for policies issued on the popular 20-Year Decreasing Term plan. For exact information on this plan and 5 what $\$ 50,000$ or $\$ 100,000$ immediate coverage would cost at your age, Either telephone collect. the TIAA LIFE INSURANCE ADVISOFV CENTER at (212) $490-9000$ and ask for an Insurance Counselor:
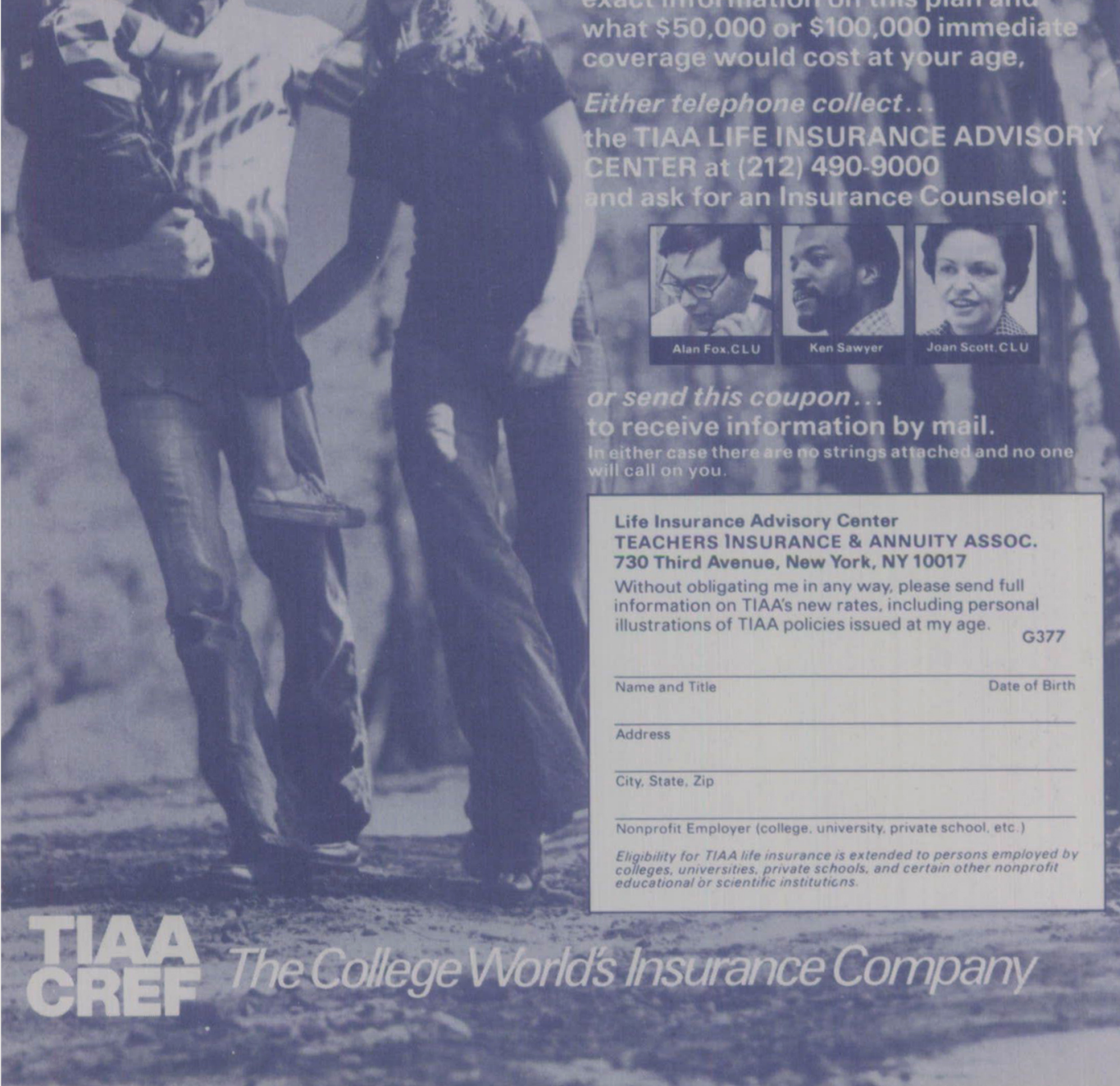


\title{
a quarterly journal
}

POLITICAL METHODOLOGY is concerned with the entire range of interests and problems centering upon how political inquiry can be conducted. POLITICAL METHODOLOGY is meant to provide a forum devoted to exploring and critically evaluating the procedures of the discipline.

The journal promotes no epistemological or methodological orthodoxy. Indeed we hope that through its articles POLITICAL METHODOLOGY gives the broadest possible range to the definition of methodology. Articles of any persuasion are welcome on such topics as comparative political analysis, experimental design, elite interviewing, formal modelling, measurement, participant observation, philosophy of science, research design, statistical methods and data analysis, survey research, and theory building and concept formation.

Manuscripts should be submitted in triplicate. As a matter of courtesy to the author, publication decisions will be made within 90 days of receipt. Manuscripts and all other editorial correspondence should be sent to:

John L. Sullivan, Editor George E. Marcus, Editor POLITICAL METHODOLOGY POLITICAL METHODOLOGY Dept. of Political Science or Dept. of Political Science University of Minnesota Williams College Minneapolis, Minn. $55455 \quad$ Williamstown, Mass. 01267

\author{
Gerald A. Dorfman, Publisher \\ Iowa State University
}

For Subscriptions, mail to:

Geron-X, Inc., Publishers -Box 1108- Los Altos, Ca. 94022

POLITICAL METHODOLOGY

Annual Subseription Rates:

$\square$ Institutional $\$ 25.00$

$\square$ Individual $\$ \mathbf{\$ 1 6 . 0 0}$

$\square$ Student $\quad \mathbf{\$ 1 2 . 5 0}$

Postage Paid Worldwide

\begin{tabular}{ll}
\hline Name \\
\hline Address \\
\hline City \\
\hline State & \\
\hline
\end{tabular}

